Journal of Educational

and Psychological Sciences

Volume (6), Issue (10) : 28 Feb 2022

P: 78 - 108

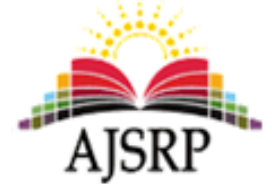

ISSN: 2522-3399

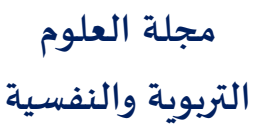

المجلد (6)، العدد (10) : 28 فبراير 2022 م

ص: 78 - 108

\title{
The Practicing Level of Formative Evaluation among High School Science Teachers and its methods in teaching science from the point of view of the teachers themselves
}

\author{
Nora Samah Lafi Alrasheedi \\ Ministry of Education || KSA \\ Nidal Shaban Alahmad \\ Al-Kharj University $\|$ KSA
}

\begin{abstract}
The current study aimed to identify the practicing Level of Formative Evaluation among high school science teachers and its methods in teaching science from the point of view of the teachers themselves, to achieve the study objectives, the qualitative approach was followed by using the observation card for the practicing of (6) science teachers for six methods of formative evaluation to measure aspects of different learning outcomes. These methods of study included: direct class questions, discussion, assignments and performance tasks, formative tests, observation, and applications. The results of the study showed that the discussion method was the most widely used among the formative evaluation methods, followed by the class questions, and that none of the six teachers used the two methods: observation or practical applications. The practices were common, and the female teachers did not use participatory evaluation methods, and they did not use self-correcting tests except for one parameter, and they did not record any evaluation activities in which peer evaluation was used. The results showed that the level of female teachers' practices of formative evaluation methods sometimes agreed with their level of knowledge of these methods, and in other times the practices were at a lower level than female teachers' knowledge of these methods, and the level of secondary school science teachers' practice of evaluation methods was rarely higher than their knowledge of them. In light of these results, the researcher recommended several recommendations, the most important of which are: training female teachers to practice the methods of formative evaluation, and to include practical applications of formative evaluation within the teacher preparation programs in the faculties of education in Saudi universities.
\end{abstract}

Keywords: Practicing degree, formative Evaluation, science teaching methods, science teachers.

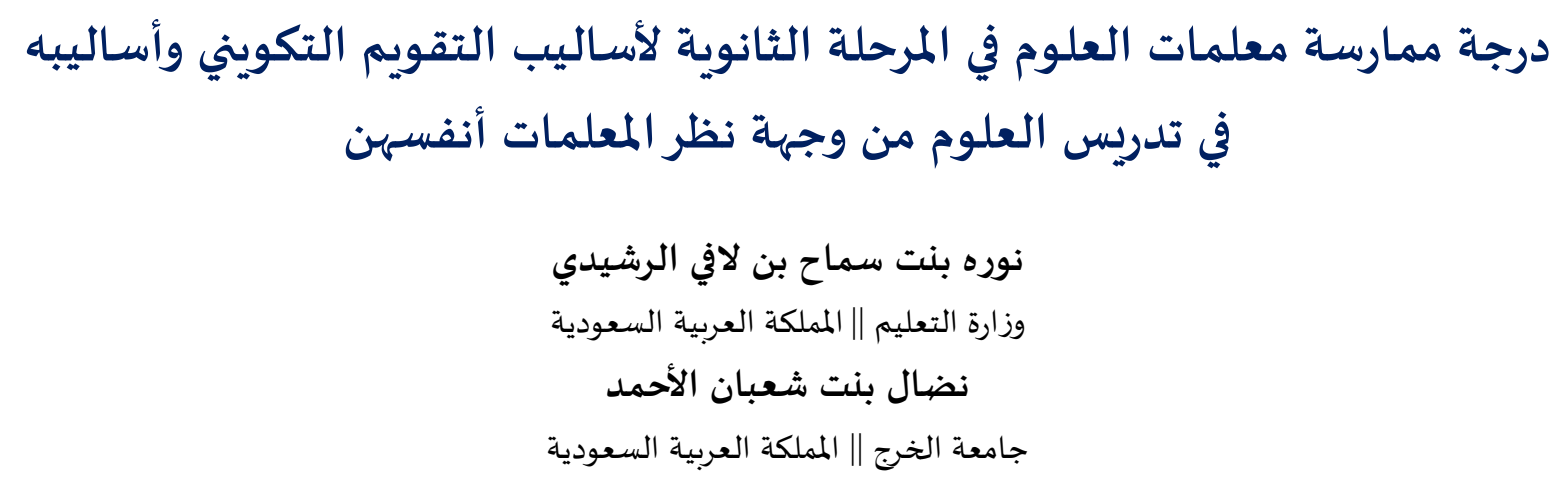


المستخلص: هدفت الدراسة الحالية للكشف عن درجة ممارسة معلمات العلوم في المرحلة الثانوية للتقويم التكويني وأساليبه في تدريس

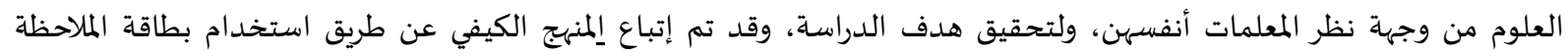

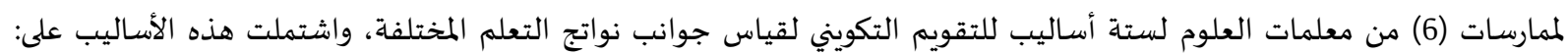

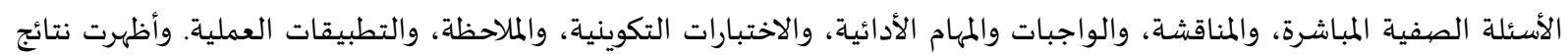

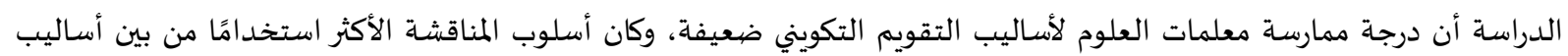

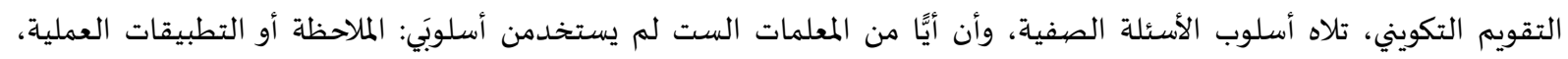

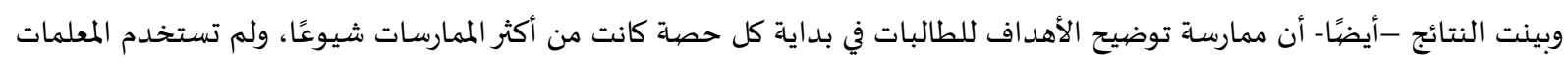

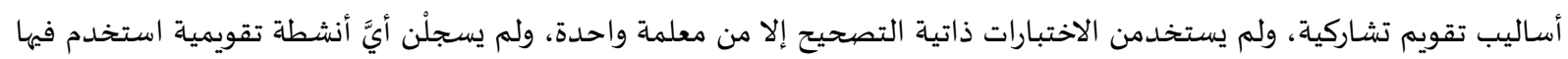

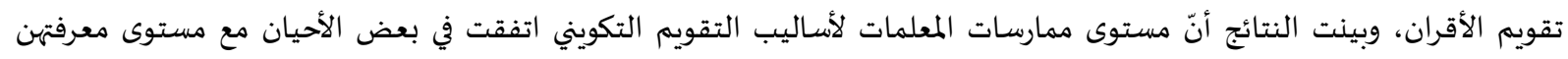

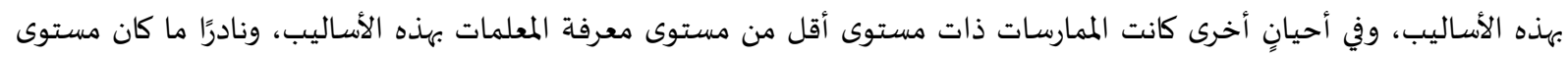

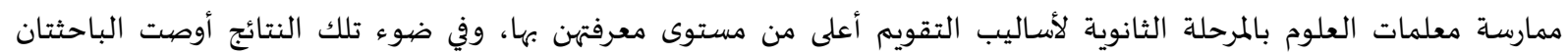

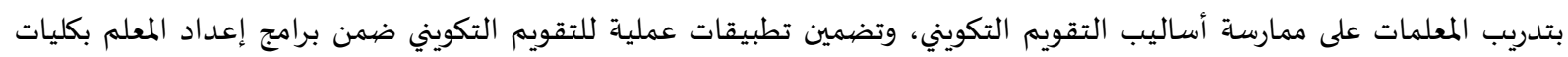
التربية بالجامعات السعودية.

الكلمات المفتاحية: درجة ممارسة أساليب تدريس العلوم، التقويم التكويني، معلمات العلوم.

المقدّمة.

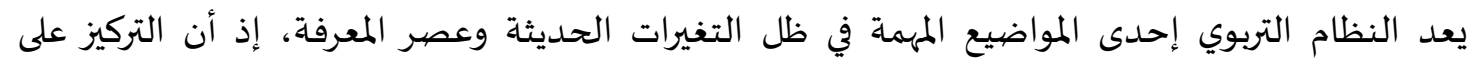
المخرجات التعليمية يسهم في إعداد جيل يحمل درجة عالية من الكفاءة والخبرة وقادر على تطوير المجتمع، ولدياه

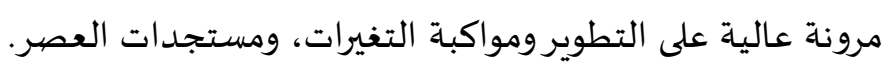
لذا يتطلب النظام التربوي استخدام وسائل القياس والتقويم الحديثة التي تسـاعد على اتخاذ التهائل قرارات تربوية موضيوعية بناء علي أسس علمية. ويعتبر التقويم ركنا أساسيًا في المنظومة التعليمية بكافة أبعادها وجوانبها، نظرًا

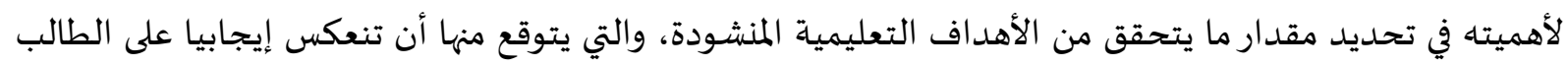

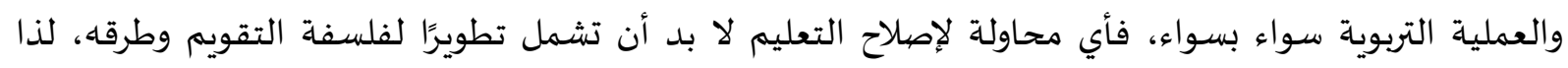

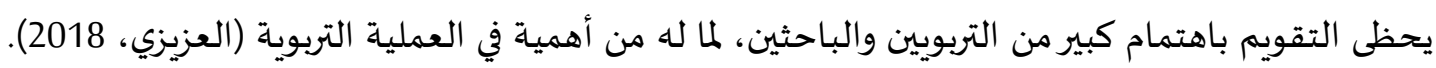

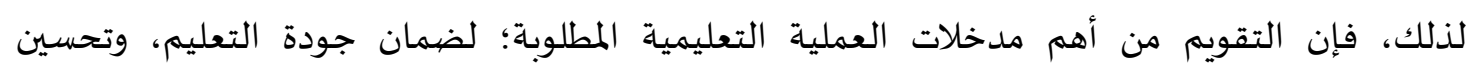

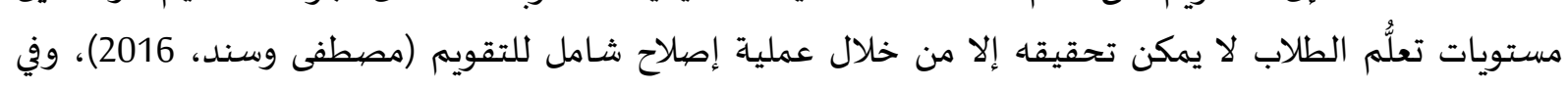
هذا أكدّت الجمعية الأمريكية لتقدم العلوم (American Association for the Advancement of Science) (AAAS)

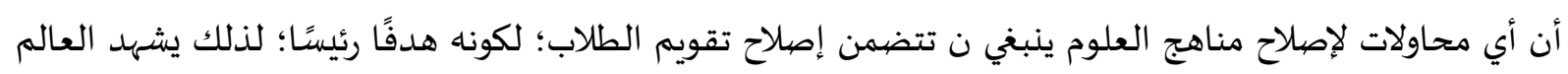

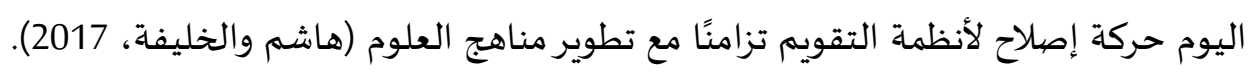

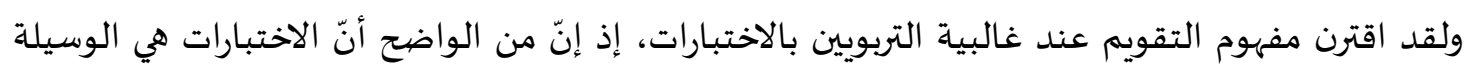

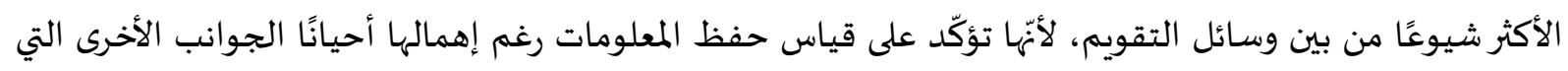

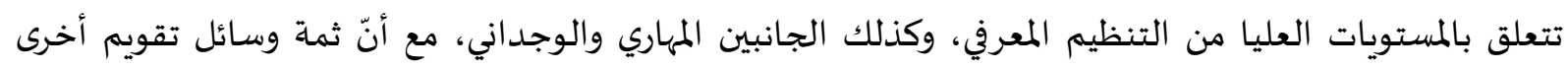

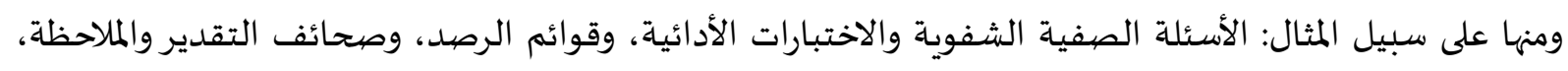

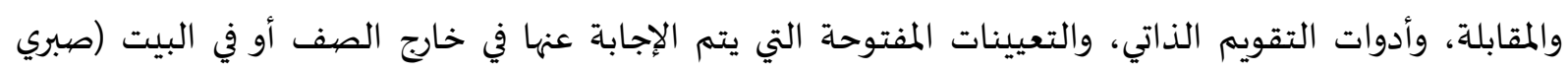
والرافعي، 2012).

وبالرجوع إلى الأدب التربوي في مجال القياس والتقويم نجد مسميات متعددة للتقويم، ومنها: التقويم البديل

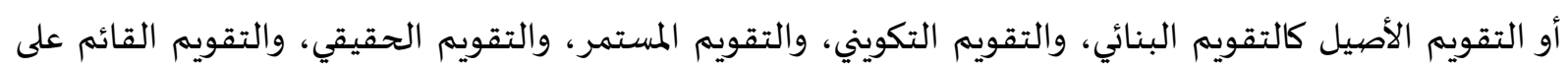


الأداء، وغيرها من المسميات، وههما اختلفت التسميات فإنّها جميعاً تشير إلى التحول من التقويم التقليدي الذي

يعتمد على الاختبارات إلى التقويم الذي يعكس إنجازات المتعلم في مواقف تعلمه واتمات واقعية (Kreusel, 2011).

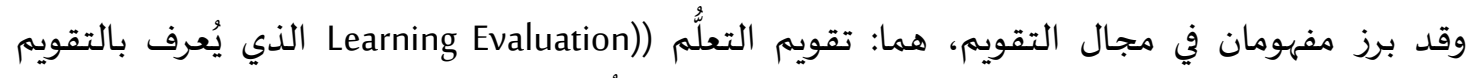

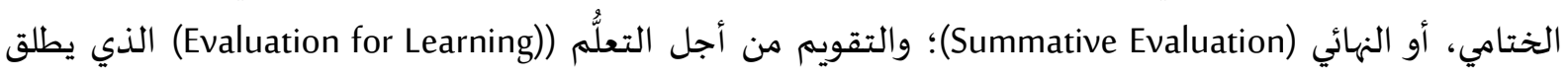

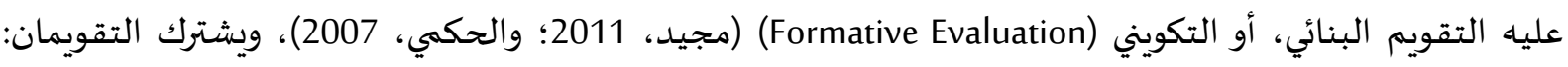

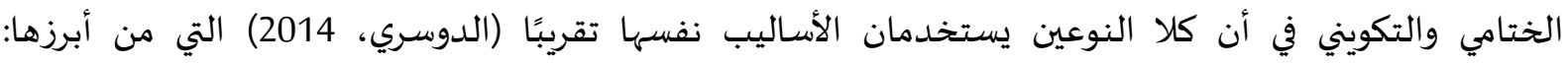

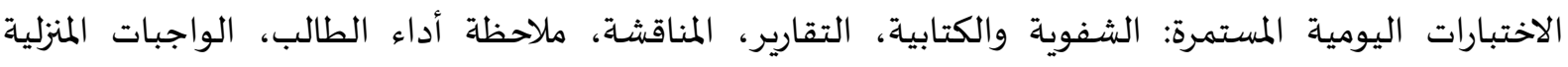

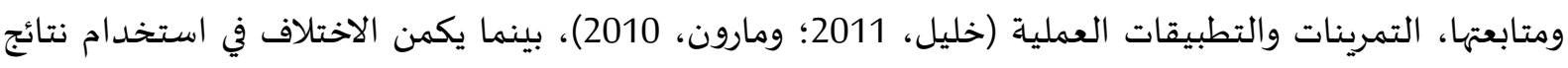
التقويم لكل منهما في صنع قرارات مختلفة (الدوسري، 2014)، ففي التقويم الختامي تستخدم نتائج التقويم للتأكد

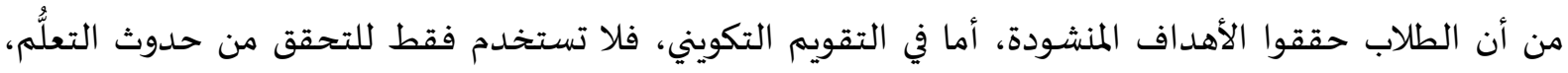

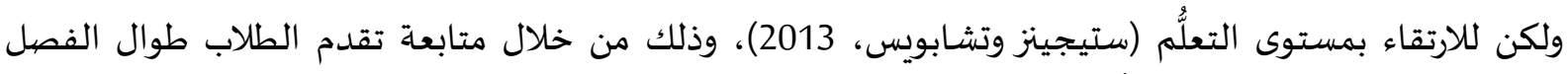

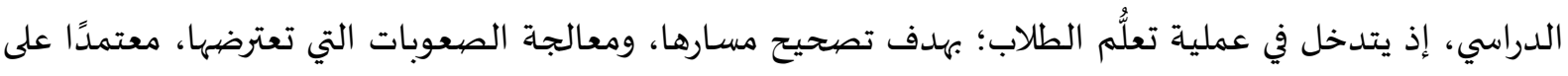

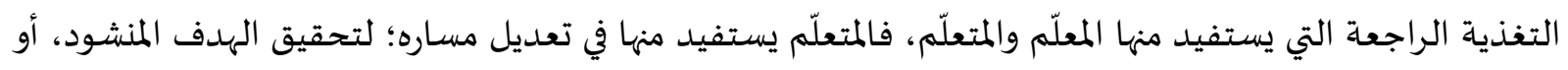

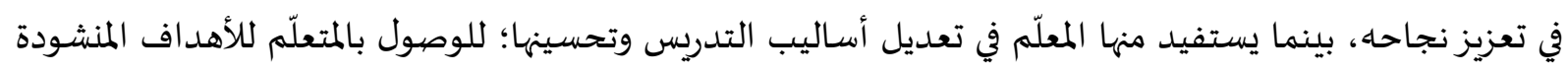

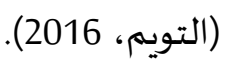

ويراعي التقويم التكويني دور التفاعل بين المعلّم والمتعلّم في عملية التعلُّم (علام، 2011)، فهو عملية تفاعلية تعزّز مشاركة المتعلم في عملية التقويم من خلال التقويم الذاتي، وتقويم الأقران والأنشطة التي تتيح للمتعلم الماتم تأمُّلَ

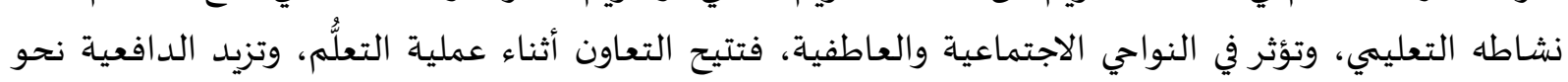

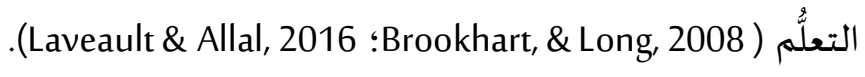
ويمثل انتقال التركيز من التقويم النهائي إلى التركيز على التقويم التكويني دليلًا وإقرارًا بأن التقويم التكويني

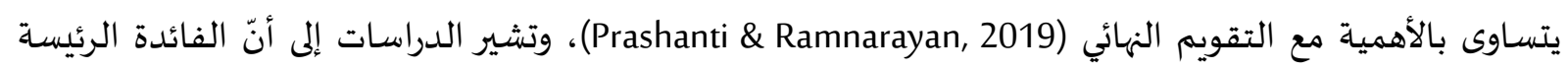

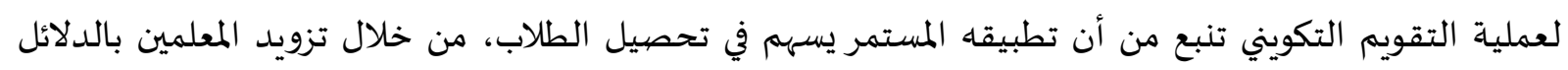

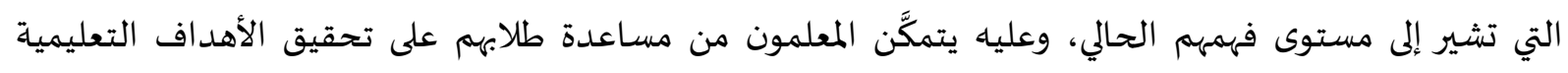

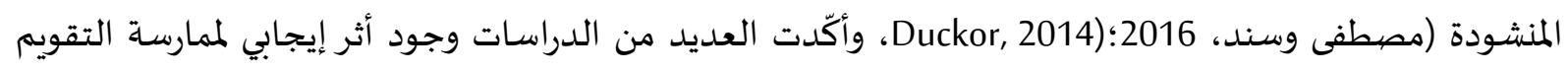

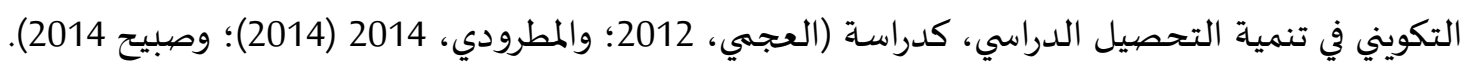

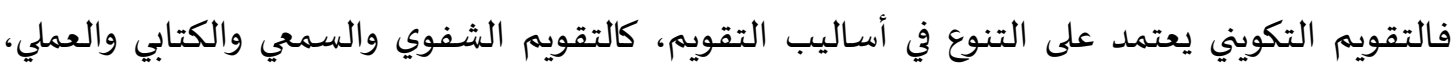
وذلك باستعمال عدة فنيات مثل الملاحظة، والاختبارات، والتقويم الذاتي، وتقويم الأقران، والحقائب التعليمية،

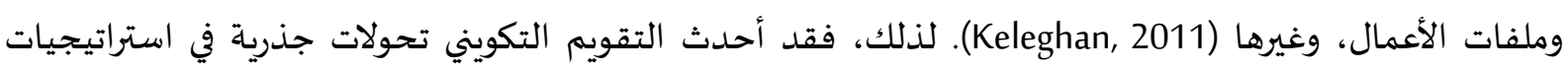
التقويم التربوي عامة وتقويم تحصيل الطلاب وأدائه، خاصة التحول من سياسة الاختبارات إلى سياسة التقويم

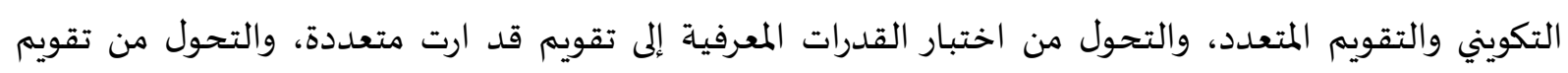

منفصل إلى تقويم متكامل ومستمر (الدوسري، 2014).

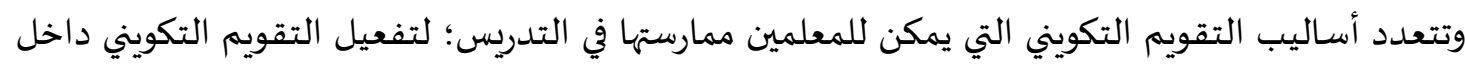

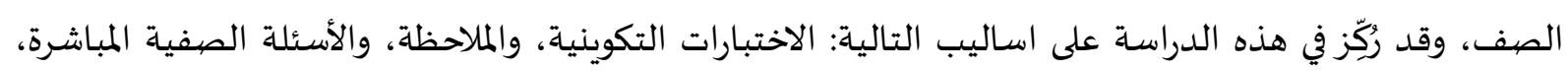

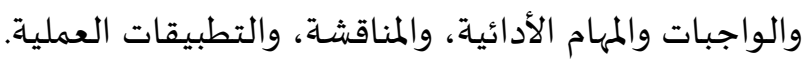


ولعل ما يبرر إجراء هذه الدراسـة وجود مؤشرات عديدة دالة على انخفاض مستوى ممارسة معلمات العلوم للتقويم التكويني وأساليبه في تدريس مادة العلوم للمرحلة الثانوية (خليل، 2011)، والتركيز على الاختبارات على أنّاء

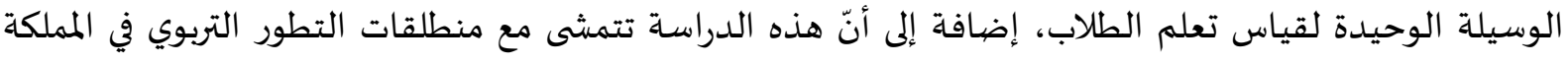

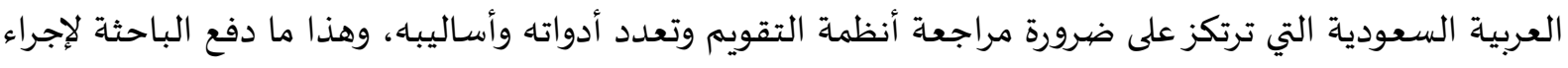
هذه الدراسة للوقوف على واقع مستوى ممارسة معلمات العلوم لأساليب التقويم التكويني للمرحلة الثانوية في مدارس محافظة الخرج.

مشكلة الدراسة: أظهرت نتائج بعض الدراسات التي اهتمت بالتقويم التكويني كدراسة (الربيع، 2018؛ القحطاني، 2018؛ منتوى (Mintert, 2019 Watkins, 2018 مستوى التعلم لدى الطلاب.

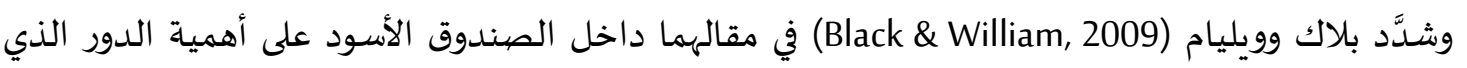

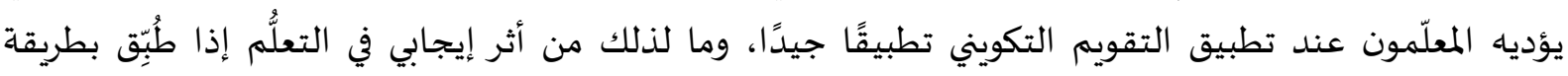

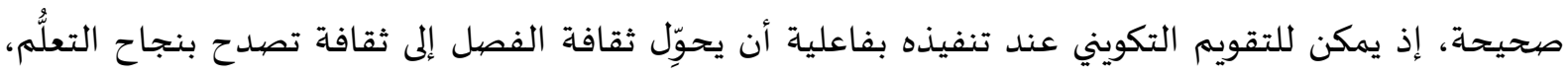

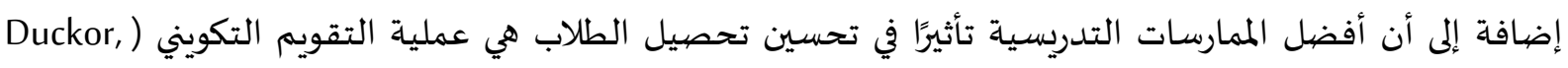
.(2014

وقد لاحظت الباحثتان أن هناك تفاوتًا واختلافًا في درجة ممارسة معلمًات العلوم لأساليب التقويم، حيث التِ

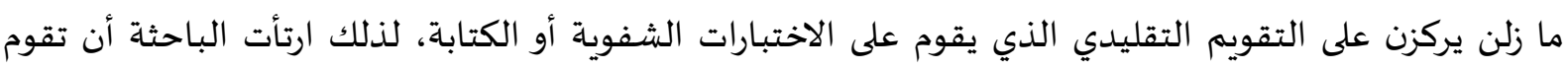

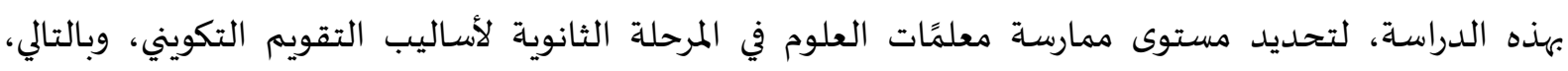

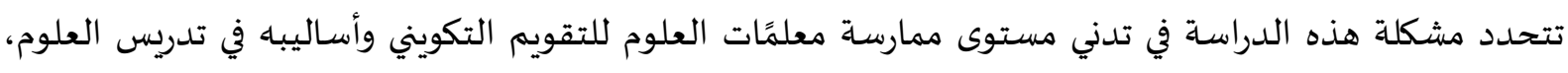
بالإضافة إلى انتشار أساليب التقويم التكويني في التدريس.

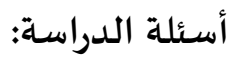
يمكن صياغة مشكلة هذه الدراسة في السؤالين التاليين:

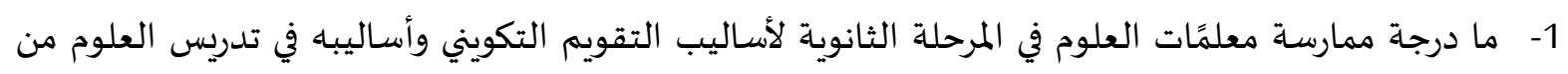

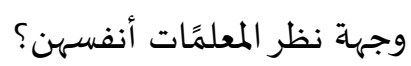
2- هل توجد علاقة بين مستوى معرفة معلمات العلوم في المرحلة الثانوية لأساليب التقويم التكويني ودرجة المعات انفئ ممارستتن لله؟ توجد علاقد

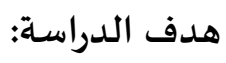

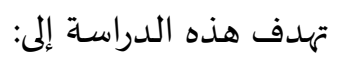
1- التعرف على درجة ممارسة معلمًات العلوم في المرحلة الثانوية لأساليب التقويم التكويني وأساليبه في تدريس التراس العلوم من وجهة نظر المعلمًات أنفسهن. 2- التعرف على ما إذا كانت هناك علاقة بين مستوى معرفة معلمات العلوم في المرحلة الثانوية لأسساليب التقويم التكويني ودرجة ممارستهن له 


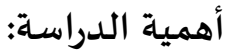

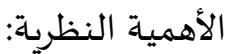

من المؤمل أن تعزز هذه الدراسـة القدرة لدى معلمًات العلوم على توظيف التقويم التكويني واستراتيجياته المختلفة في تدريس العلوم.

- كما قد تفتح المجال للباحثين في مناهج وطرق تدريس العلوم الطّريق لإجراء المزيد من البحوث حول مستوى ممارسة التقويم التكويني بطريقة فاعلة في تدريس العلوم واختبار فاعليته في تنمية متغيرات أخرى في المناهيج

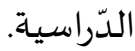

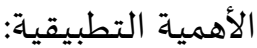
قد تفيد نتائج هذه الدراسة القائمين على برامج تأهيل معلمًات العلوم وإعدادهنّ للتدريس، وإدارات التدريب التربوي مما يزودهم بمعلومات عن طرق توظيف أساليب التقويم التكويني في التدريس، مما يساعد في في تحديد حاجة المعلمًات للبرامج التدريبية. وربما تفيد واضعي المنهج في تصميم أدوات واستراتيجيات التقويم التكويني وتضمين طرقاه وأساليبه المعتمدة ضمن أدلة المعلمين المرافقة للمنهج لمساعدة المعلمين على توظيفها بطرق أكثر فاعلية.

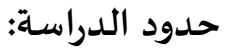
الحدود الموضوعية: درجة ممارسة معلمًات العلوم بالمرحلة الثانوية بمحافظة الخرج لأساليب التقويم التكويني

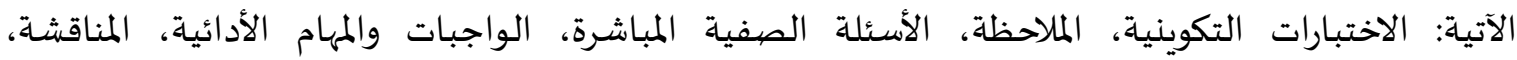

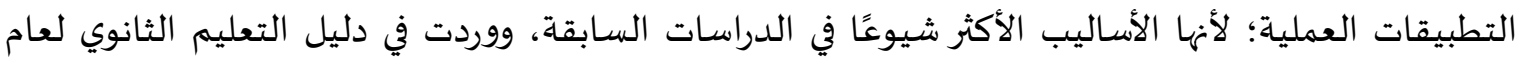

الحدود البشريـة: معلمًات العلوم بمحافظة الخرج.

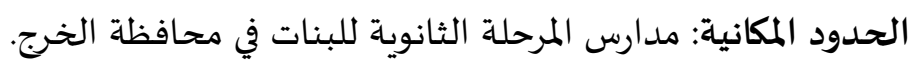

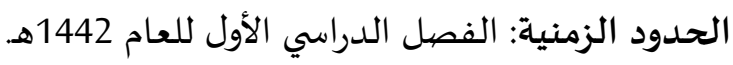

مصطلحات الدراسة وتعريفاتها الإجرائية:

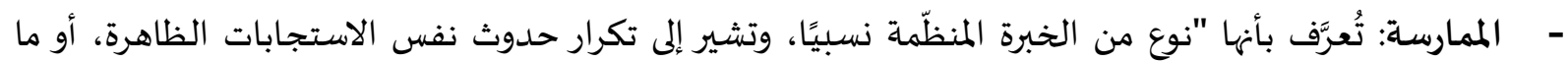

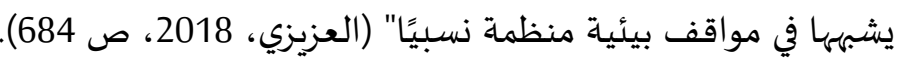

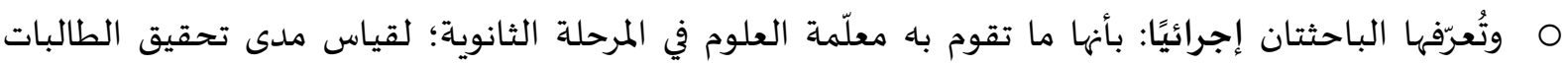

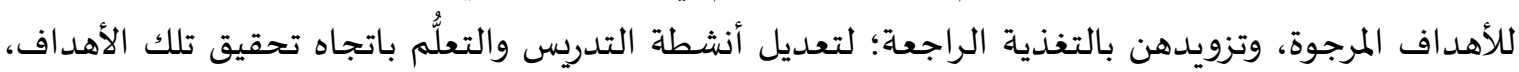

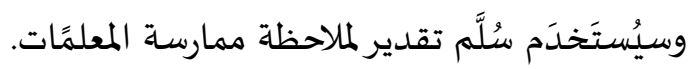
- التقويم التكويني: عملية تقويمية منظمة تحدث أثناء التدريس، وتعمل على إعطاء تغذية راجعة، بهدف تحمقيق الطلاب للمخرجات التعليمية المرجوة (Mintert, 2019, p, 25).

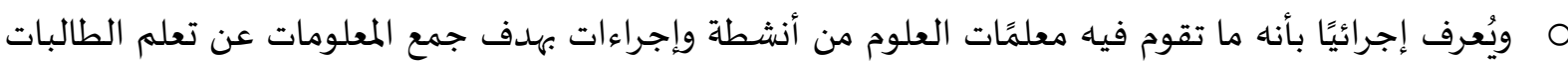

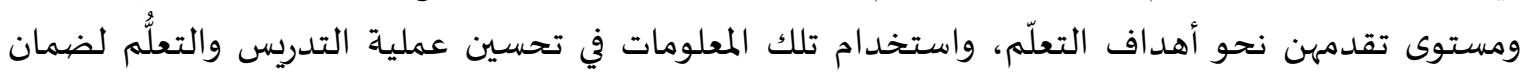
وصول المتعلمات للأهداف المرجوة. 
- أسـاليب التقويم التكويني: عرَّف هاشم والخليفة (2017، ص 69) أساليب التقويم بأها "الطرق، والإجراءات

التي يتبعها المقوّم لتنفيذ عملية التقويم". O وتُعرّهها الباحثتان إجرائيًا: بأهها الطرائق المتنوعة للتقويم التكويني المخطط لهاب، والمُعَدَّة مسبقًا من معلمة

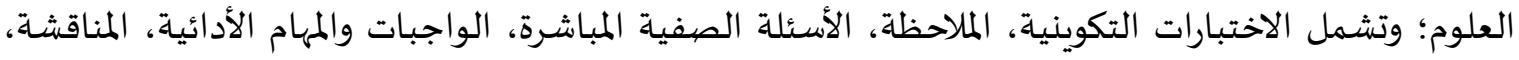
التطبيقات العملية، وتهدف الحصول على معلومات عن تقدم الطالبات في تعلُمِهِن وتقديم التغذية الراجعة؛ لتحسين عملية التعلُّم.

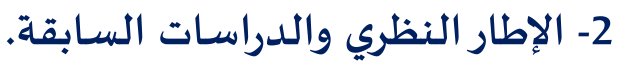

أولًا: التقويم التكويني

تعددت تعريفات التقويم التكويني، إذ عرفه بلاك ووليام (Black \& Wiliam, 2009,p. 54) بأنه كل الأنشطة التي يقوم بها المعلمون، أو طلاههم التي توفر معلومات جاهزة للاستخدام: بكونها تغذية راجعة؛؛ لتعديل أنشطة التعليم والتعلم التي ينخرطون فيها. ويُعرَّف بأنه عملية مخططة ومستمرة، يستخدمها جميع الطلاب، والمعلمين أثناء التعلم والتدريس؛

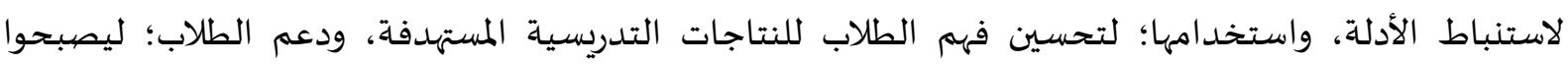

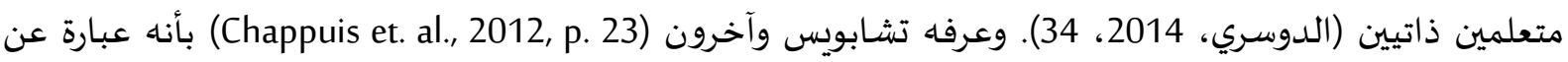
عمليات منظمة وعشوائية، يستخدمها المعلمون والطلاب؛ لجمع الأدلة؛ بهدف تحسين العين العملية التعليمية.

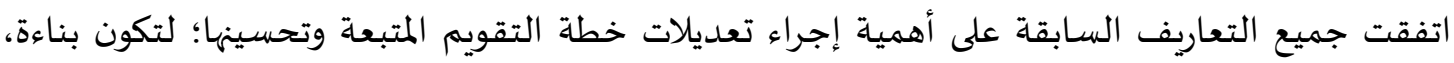

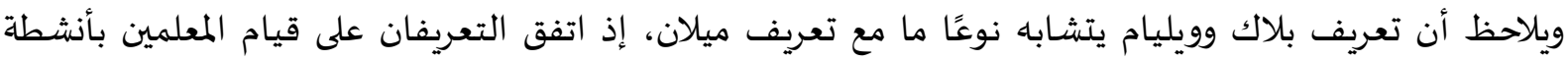

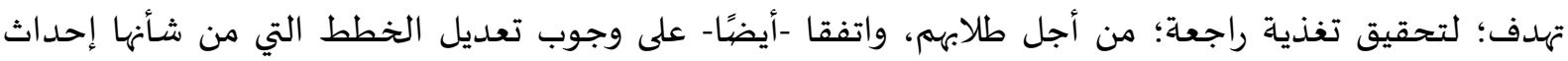

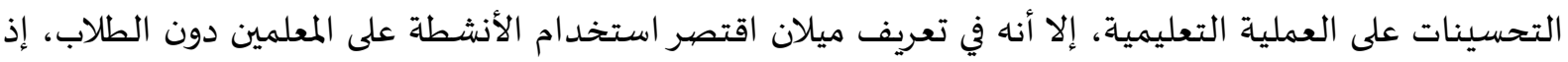

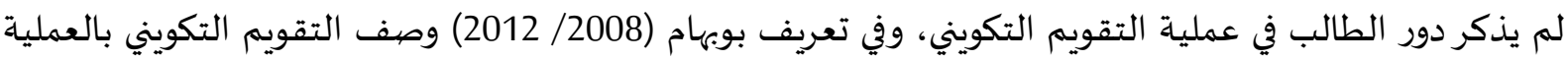

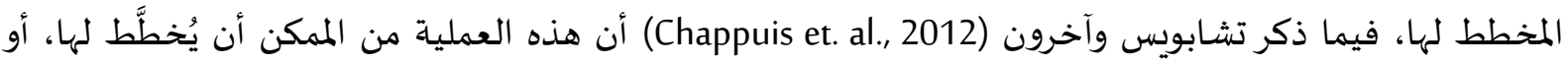

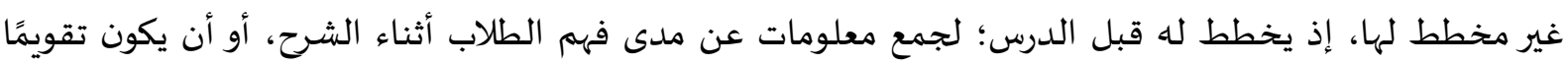
تكوينيًّا غير مخطط له دون سابق إنذار.

أهمية التقويم التكويني: يكتسب التقويم التكويني أهميته من تأثيره في أداء الطلاب الذي أكّدته العديد من الدراسات: كدراسة بلاك

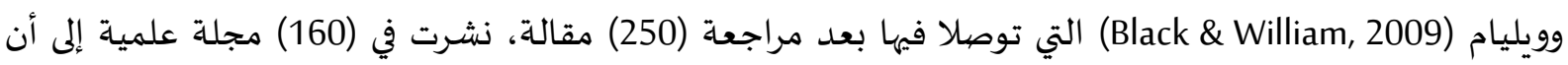

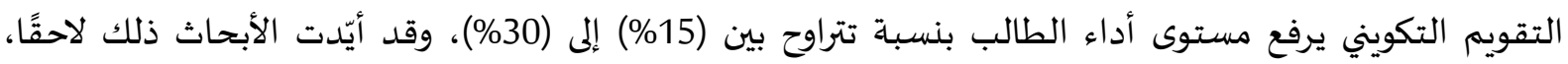
ويدعم التقويم التكويني الاستقلالية في التعلم، فعندما يفهم الطلاب أهدافهم وأدوارهم في التعلم يكونون أكثر الترات استقلالية ووعيًا بما ينبغي لهم القيام باه، ويتحملون مسؤولية تعلمهم، تركز ممارسات التقويم التكويني على التعلم،

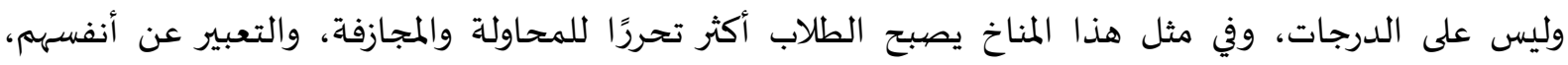

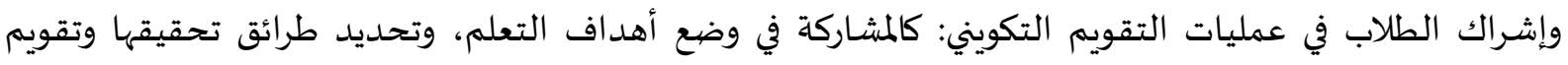

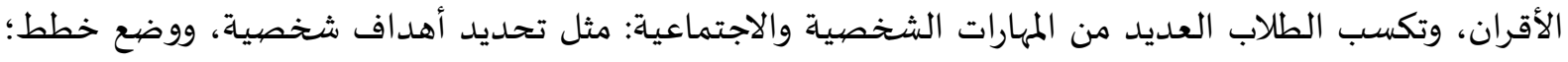


لتحقيقها، وتحمل المسؤولية (السعدوي، 2018)، ويجعلهم مسؤولين عن تعلمهه، ويكسبهم مهارات التقويم الذاتي،

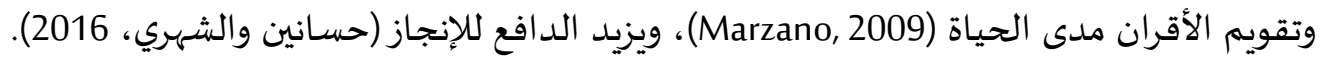

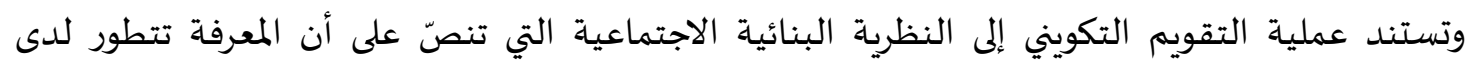

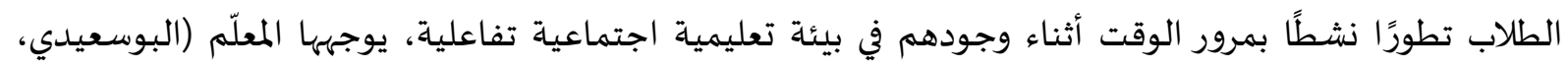

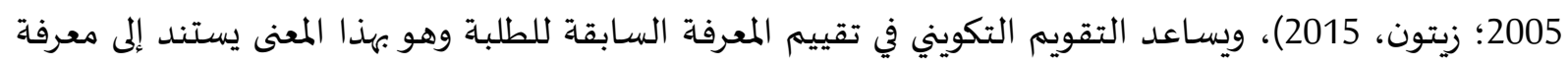
المتعلمين السابقة ويبني عليها، بحيث يمكن المعلم من معرفة نقاط القوة والضيعف في معرفة الطلبة، ومن ثمّ تتطور

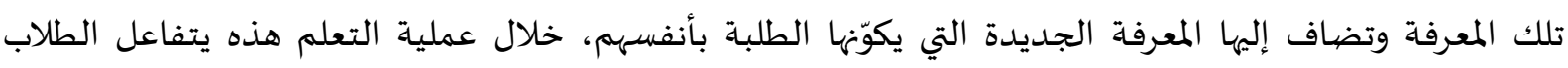

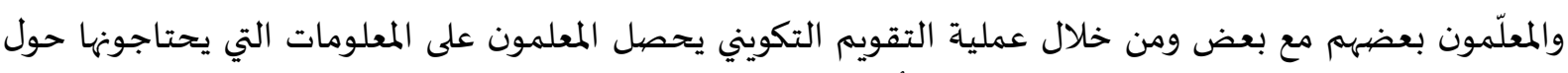

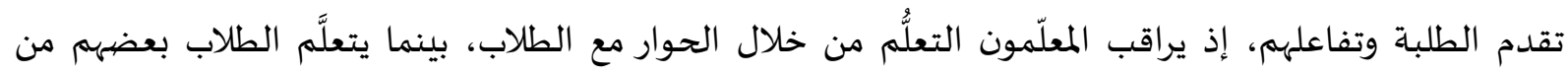

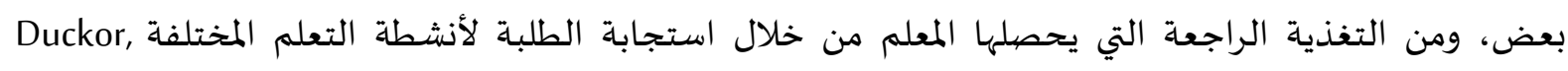

\section{استراتيجيات التقويم التكويني:

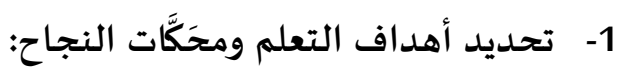
تبدأ عملية التقويم التكويني بمشاركة المعلم أهداف التعلم مع الطلاب، إذ لا يقتصر فهم أهداف التعلم

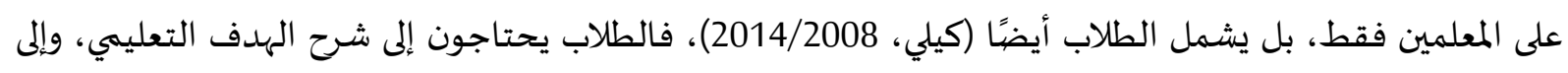

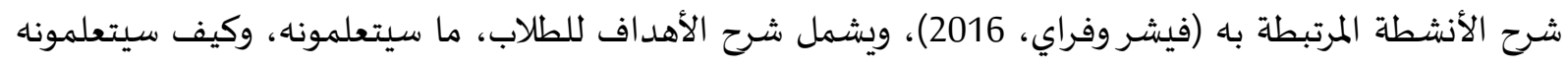

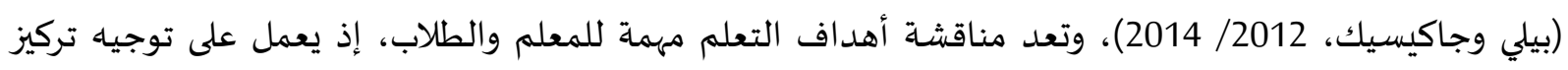

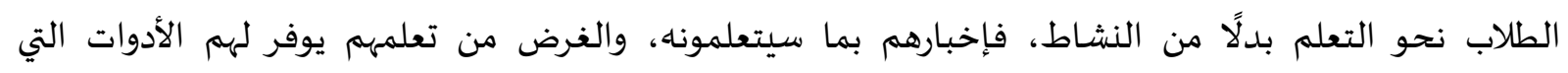

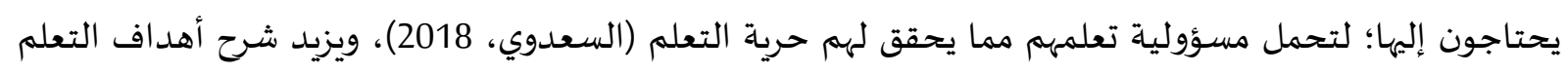

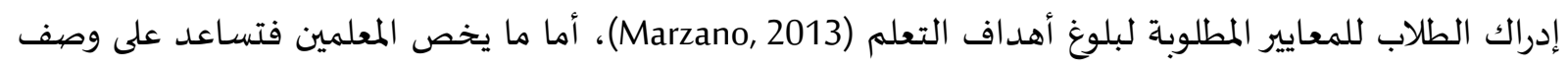

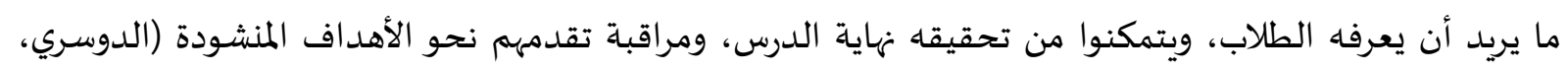

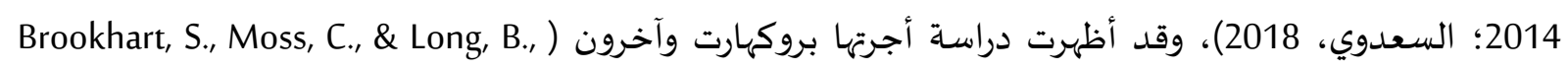

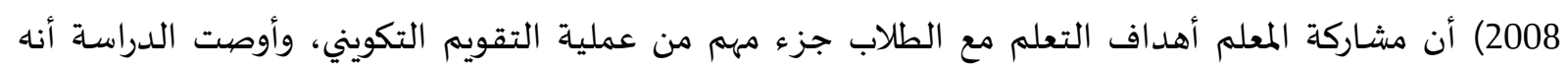

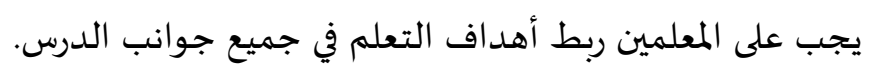

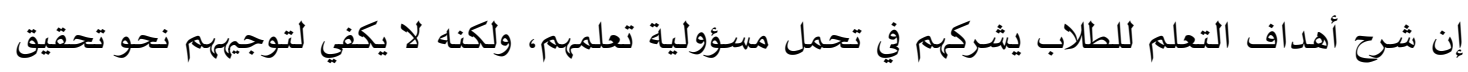

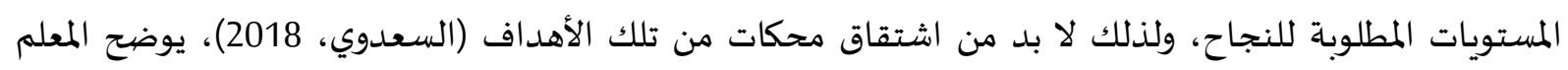

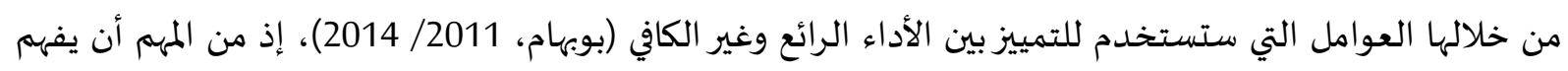

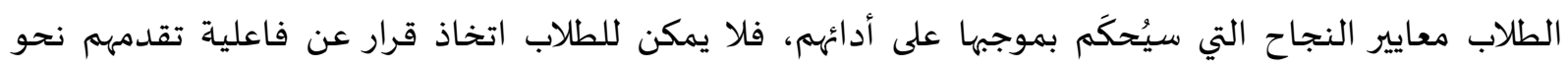

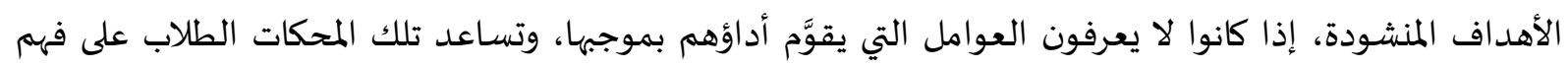

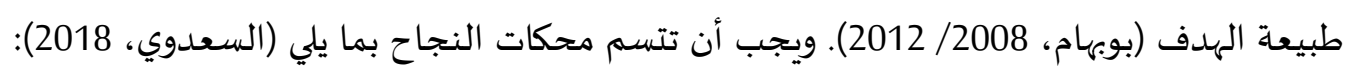
1. ترتبط بأهداف التعلم. 2. 2 تختص بنشاط محدد. 3. تدعم تركيز الطلاب، وهم منخرطون في النشاط.

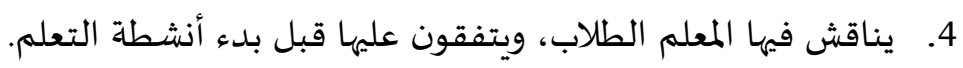


5. تكون الأساس الذي يبني عليه الطلاب التغذية الراجعة، وتقويمهم أنفسهم، وتقويم بعضهم.

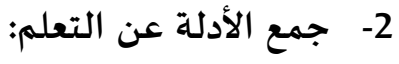

حيث يجمع المعلم بيانات الطلاب؛ لمعرفة مدى تحسن تعلم الطلاب، وحاجات التعلم لكل طالب وحده، وللطلاب عمومًا، واكتشاف نقاط القوة التي لم تكن معروفة لديهم، وطرح المعلم الأسئلة حول ممارساته وطرائق تحسين التدريس (الدوسري، 2014)، بعد أن يجمع المعلم بيانات التقويم التكويني فإن المهمة الأساسية هي استخدام تلك البيانات لتوجيه التدري والتعلم. إذ يحلل المعلم البيانات بعد جمعها؛ لتحديد مستوى معرفة الطلاب،

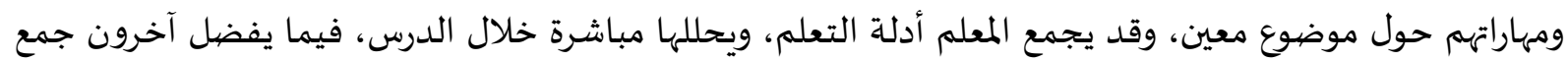
الأدلة، وتحليلها بعد نهاية الدرس (Marzano, 2012).

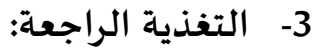

يرتبط نجاح التقويم التكويني بالتغذية الراجعة، وتُعرّف (مجيد، 2011) التغذية الراجعة بأهها المعلومات التي تجمع حول مدى تحقيق الفرد لهدف أو غرض معين، ويعتمد جزء كبير من عملية التقويم التكويني على تقديم تغذية راجعة متخصصية مستمرة للطلاب، فبدون التغذية الراجعة لا أهمية لجمع بيانات الطلاب، ففي النهاية

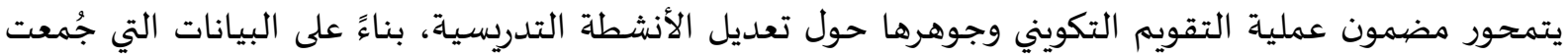

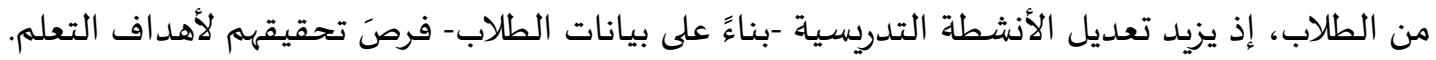
وتوجه التغذية الراجعة الطلاب نحو توظيف استراتيجيات محددة، يتوجب عليهم استخدامها لتحقيق التحسن المنشود (الدوسري، 2014)، وتشجع التغذية الراجعة التفكير ما وراء المعرفي، وتنهي في الطالب التنظيم لتهيه الذاتي، وتمنحه الشعور بالاستقلالية (فيشروفراي،2016)، وكشفت عدد من الدراسات عن دور التغذية الراجعة في

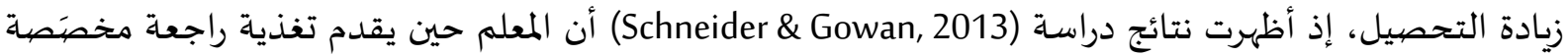
ومهمة لطلابه في وقت قصير يتحسن تحصيلهم التعليمي، ولا تنحصر فائدة التغذية الراجعة في الطلاب وحدهم، إدها

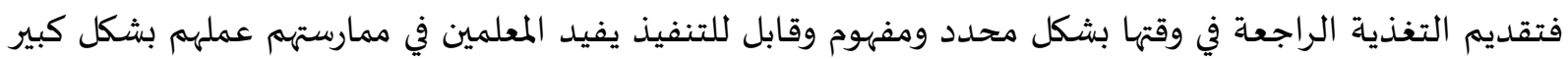

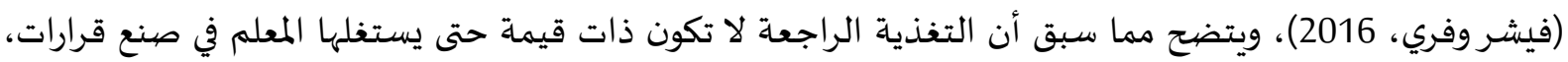

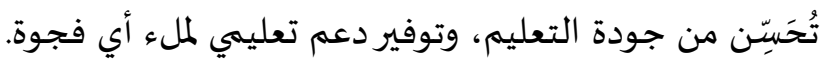

التقويم الذاتي: حيث يقوم الطلاب تحديد نقاط تعلمهم الحالية ومقارنتها بالتعلم المستهدف والإتقان، ويشاركون في وضع أهداف التعلم؛ لغرض تحسين الأداء (الدوسري، 2014)، ويقدم التقويم الذاتي معلومات مفيدة، تعبر عن رأي الطلاب في تحقيقهم لأهداف التعلم المنشودة، ويشرك الطلاب في عمليات تعلمهم، وتحميلهم مسؤولية أعمالهم،

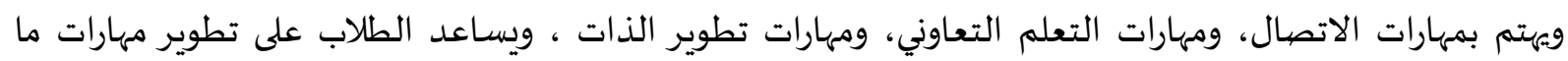

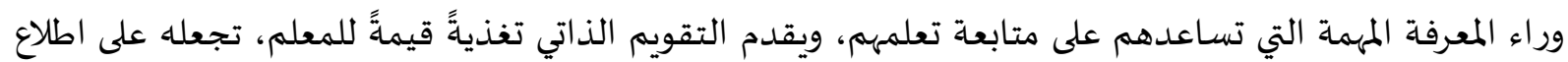

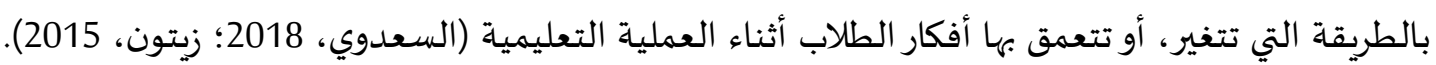

$$
\text { تقويم الأقران: }
$$

وفيه يسمح للطلاب بتقويم زملاههم وتقديم التغذية الراجعة لهم بشكل هادف وفعال بدعم من المعلم

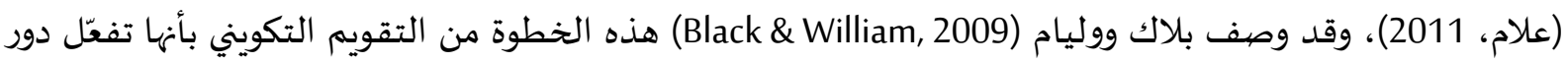

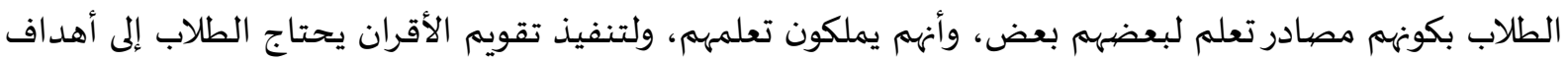
تعلمية واضحة، وأن يكونوا مدربين على طريقة تقويم عمل زملائهم بطريقة مثمرة، ويجب أن تكون عملية تقويم 
الأقران متبادلة، إذ يتاح لكل طالب الفرصة بتقويم عمل أحد الأقران، ولا يجب أن يركز تقويم الأقران على نتائج

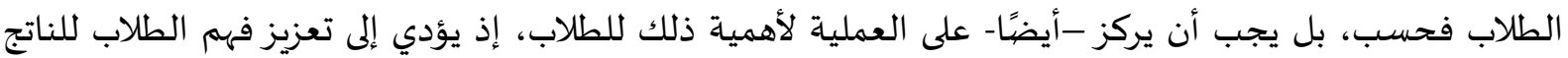

.(Topping, 2013)

ولا تقتصر فائدة تقويم الأقران على الطالب، إنما تتعداها إلى المعلم، إذ يوفر للمعلم معلومات حول مدى

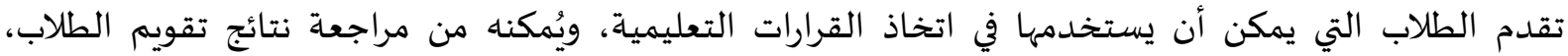

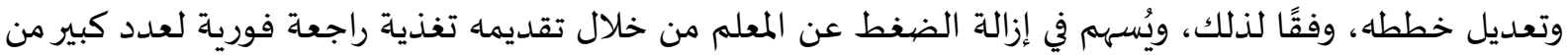

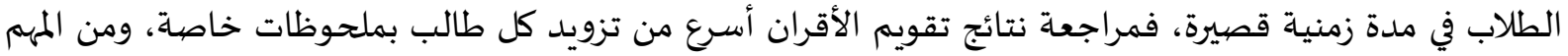

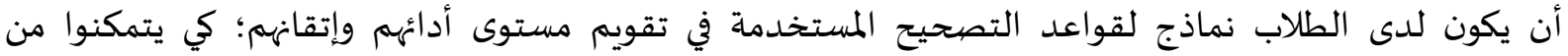

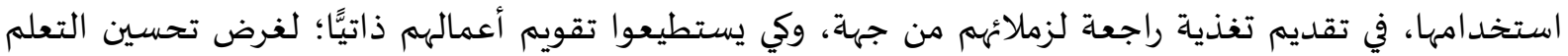
وتطويره، وتحسين قدرتهم على التقويم الصحيح؛ ليكون قريبًا من تقويم المعلم (الدوسري، 2014).

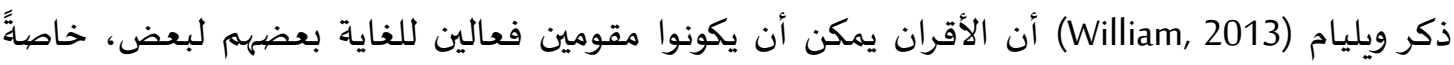
عندما يكون التركيز على التحسين، وليس التصنيف بالدرجات، والطلاب يميلون إلى أن يكونوا أكثر صرامة، بعضيه بهنه

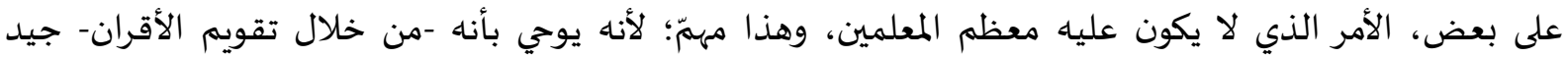

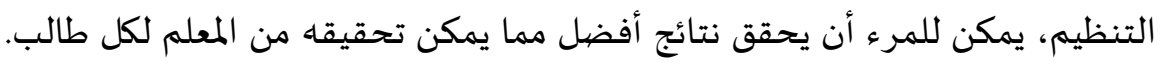

أساليب التقويم التكويني: تتعدد الأساليب التي يمكن للمعلمين توظيفها؛ لتفعيل التقويم التكويني داخل الصف، وقد ريكّز في هذا

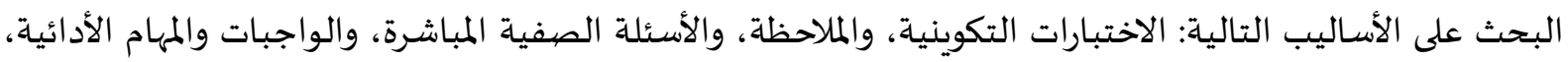

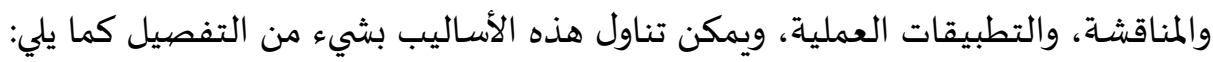

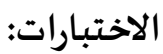

هي اختبارات تطبق أثناء سير العملية التعليمية، إذ يخصص لكل موضهوع، أو فصل اختبار منفصل؛ من

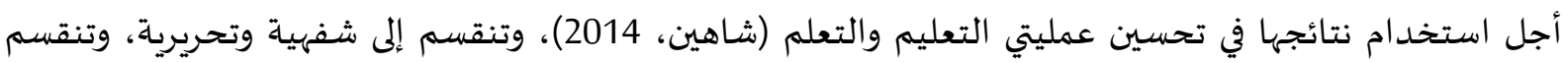
التحريرية إلى مقالية وموضوعية (السعدوي، 2018)، وتتطلب عملية إعداد الاختبارات التكوينية تحديد الأهداف

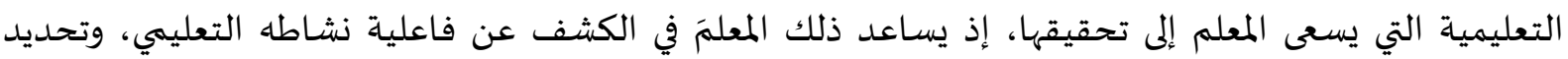

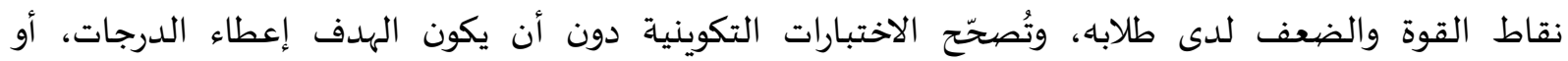

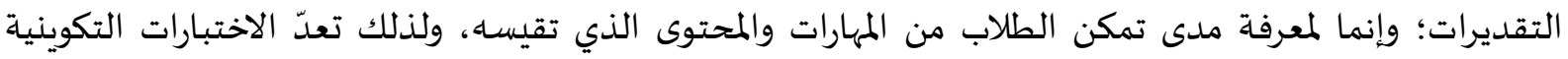

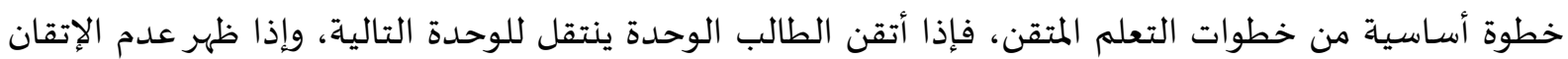
فلا بد من تشخيص حالته، ومعرفة ما ينبغي عمله؛ حتى يصل إلى مستوى الإتقان لهذه الوحدة هاشم والخليفة،

وتعدّ الاختبارات التكوينية بمنزلة تعزيز للطالب عندما يعرف هل اقترب من تحقيق الأهداف، أو لم يقترب، ويستطيع الطالب تحديد جوانب ضعفه من خلال معرفة الأسئلة التي لم يستطع الإجابة عنها في الاختبار والمهارات والمعلومات التي يحتاج إلى دراستها، فيحاول أن يبذل الجهد؛ للوصول خلأل للأهداف المراد تحقيقها (عطية، 2008)، وتسهم الاختبارات التكوينية في إزالة الخوف والقلق عند الطلاب من اختبارات التقويم النهائي، إذ يزول بشكل تلمعل تدريجي

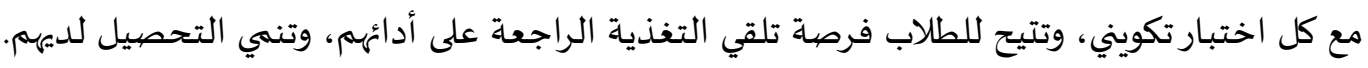


وتعدّ الملاحظة من أساليب التقويم التكويني التي يمكن أن يستخدمها المعلمون في جمع البيانات، وتتضمن

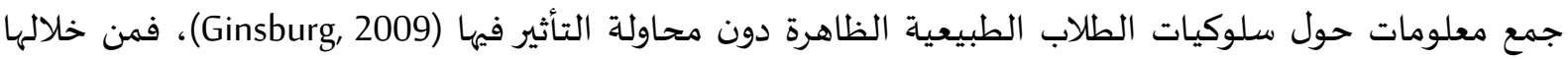
يتسنى للمعلم تحليل حاجات تعلم طلابه؛ ليحدَد أيَّاَ منها يستدعي برنامجًا علاجيَّا، أو إثرائيًا، فالمعلمون من خلال ملاحظتهم لطلابهم ضمن أهداف التعلم يمكنهم تحديد نقاط القوة، ونقاط الضعف لديهم، وتحديد المواضع التي

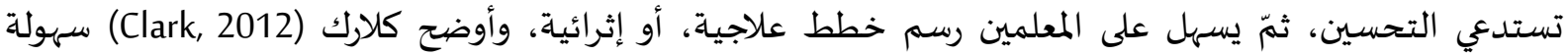
تطبيق ملاحظة الطلاب يوميًا خلال إجراء التجارب، وخلال الأنشطة الصفية والمناقشات. في أسلوب الملاحظة يراقب المعلم طريقة تعلم الطلاب من خلال انتقال المسؤولية المعرفية منهم لطلاههم (فيشر وفراي، 2016)، فالمعلم يلاحظ سلوك الطلاب عندما يقومون بالأنشطة المتنوعاة؛ حتى يتمكن من توجيههم وإرشادهم، ولا بد للمعلم عندما يقوِّم بأسلوب الملاحظة من أن يستخدم لغة وصفية سليمة؛؛ لتسجيل الملحوظات، وأن يعرف الهدف الذي يبحث عنه من خلال ملاحظته (هاشم والخليفة، 2017).

الأسئلة الصفية المباشرة:

إن استخدام أسلوب الأسئلة الصفية في التقويم التكويني يركز على تعلم الطلاب، ويزودهم بالتغذية الراجعة عن تعلمهه، وهذا ما يميز الأسئلة الفعالة عن غير الفعالة التي تهدف فقط إلى إثارة انتباه الطلاب، وضبط

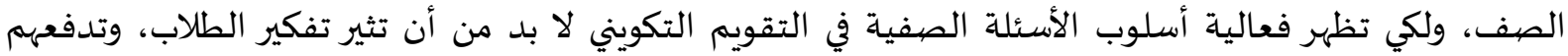
للنقاش والتفاعل مع زملايهم؛ للحصول على إجابة، ويجب أن تركز على الطلاب، وتزودهم بالتغذية الراجعة عن تعلمهم (Duckor,2014). وتوجد بعض الطرق التي يمكن استخدامها؛ لطرح الأسئلة الفعالة على الطلاب، منها: التخطيط لطرح

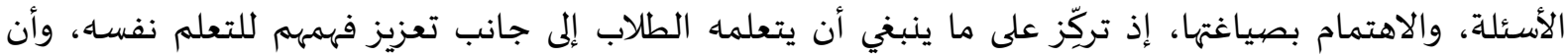

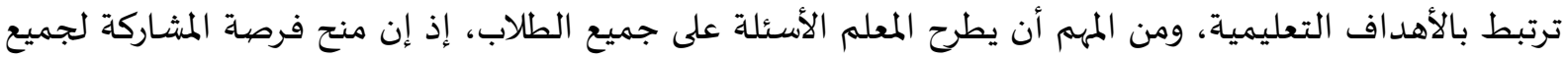

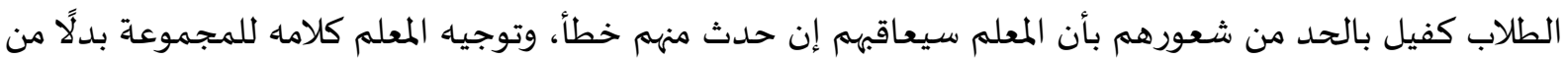

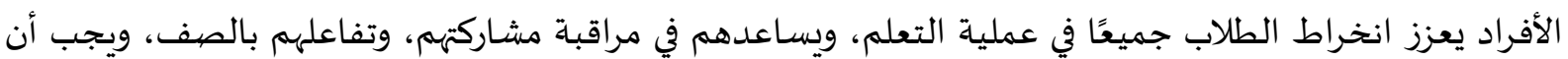

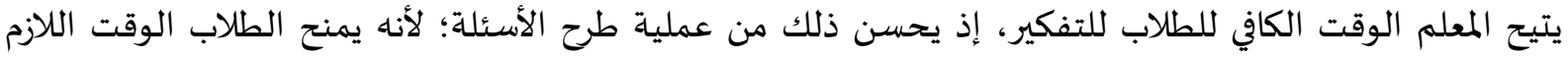

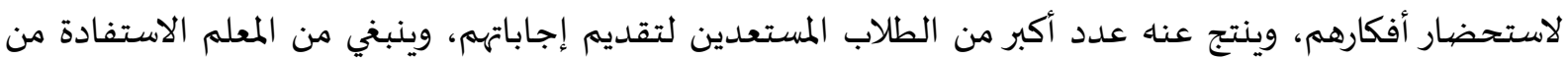
الإجابات الخطأ بتحويلها إلى نقطة انطلاق؛ لتحسين الفهم (السعدوي، 2018؛ زيتون، 2015؛ Duckor,2014).

الواجبات المنزلية:

الواجبات المنزلية هي مهمات يُطلب من الطالب تنفيذها في المنزل؛ وتكون امتدادًا للأعمال الصفية ومكملة

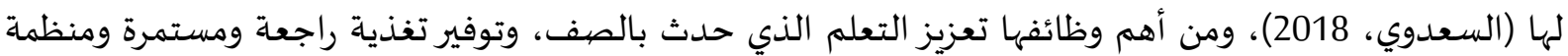

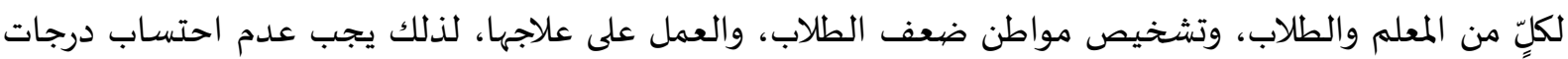

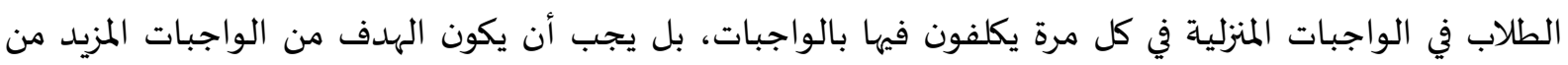

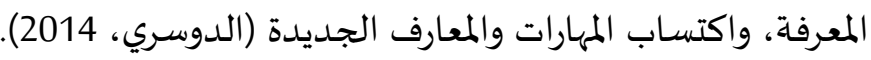

يجب تشجيع الطلاب على الحوار مع المعلم؛ لتعميق فهمهم بالواجبات المنزلية، إذ يجب التحقق من فهم

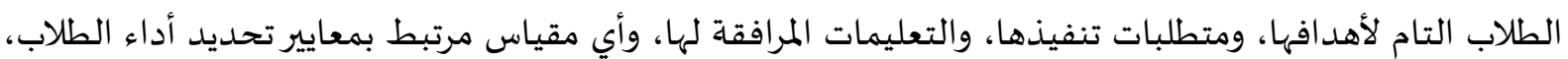

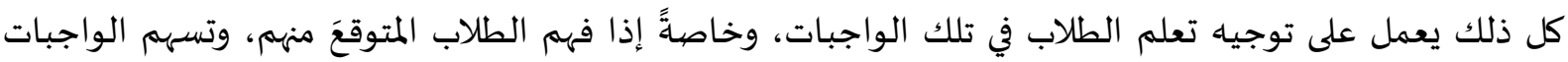


المنزلية في زيادة تحصيل الطلاب وتدعم تحقيق الأهداف التعليمياة، فالمعلم عندما يجتهد بإعداد الواجبات وربطها

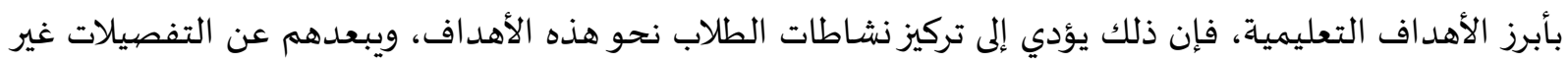

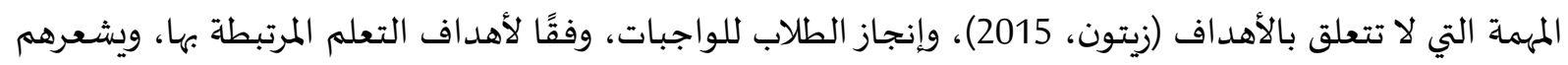

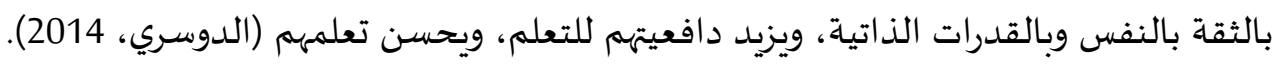

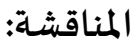

المناقشة هي عبارة عن حوار شفهي بين المعلم والطلاب، يكون فيه للطلاب دور إيجابي في جو غير مختلق

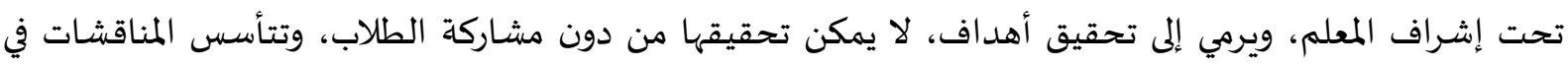

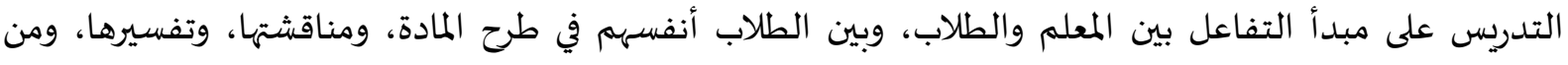

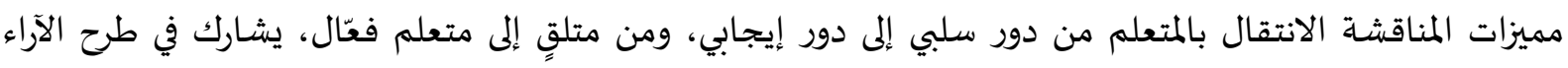

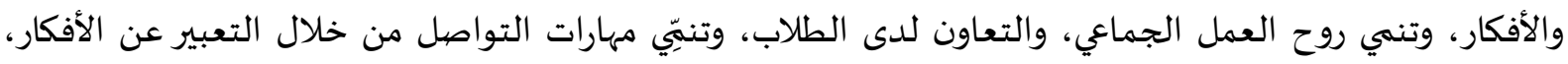

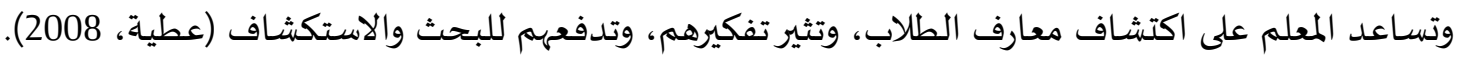

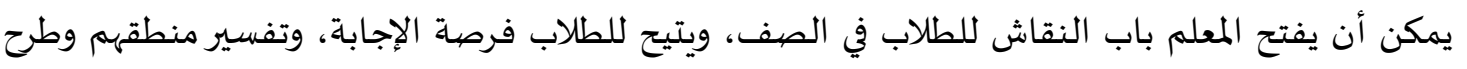

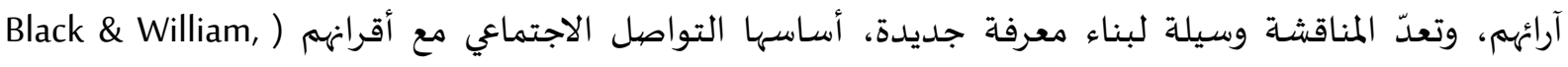

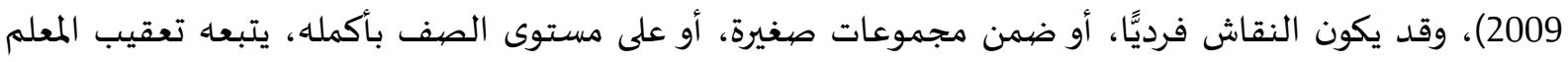

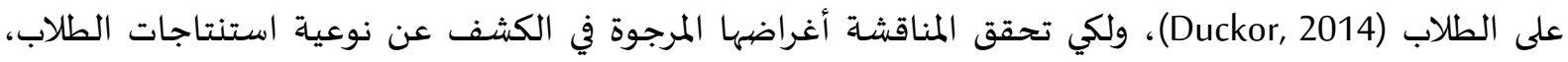

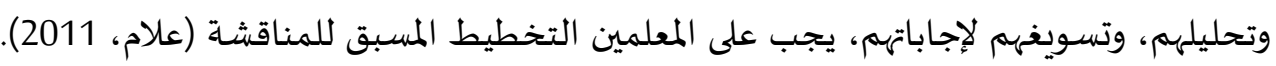

ثانيًا- الدراسـات السابقة: أجريت العديد من الدراسات التي تناولت تقويم تعلم الطلاب وأدواتها المختلفة، ومن أمثلة تلك الدراسـات: - دراسة العزيزي (2018) التي هدفت إلى التعرف على فاعلية استخدام التقويم التكويني في تحسين مستوى

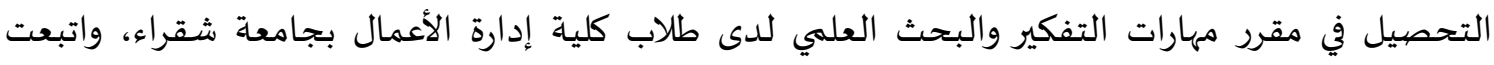

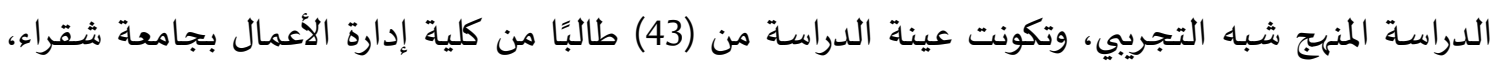

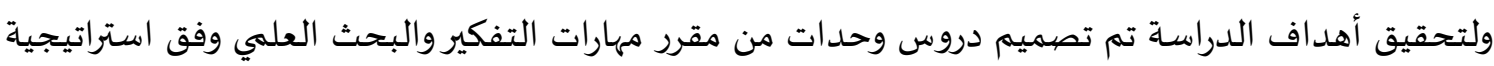

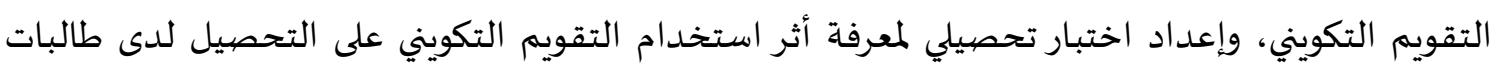

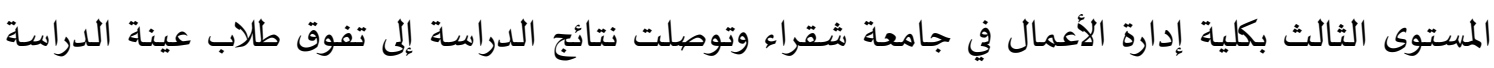
التجريبية بعد استخدامهم للتقويم التكويني في التحصيل. - ودراسة العبد الكريم والشائع (2018) والتي هدفت إلى معرفة أثر أنموذج مقترح للتقويم من أجل تعلم

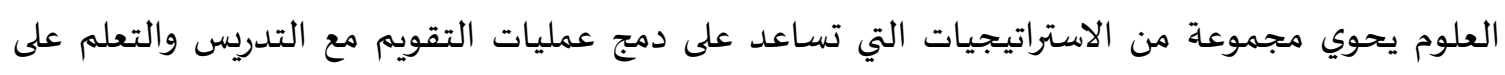

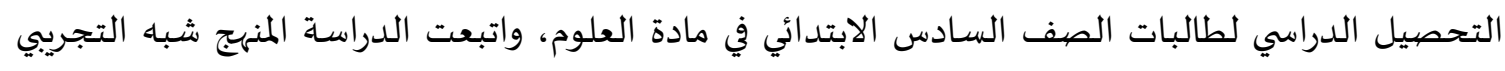

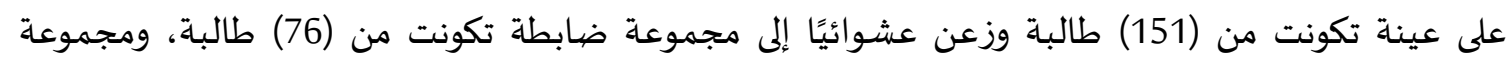

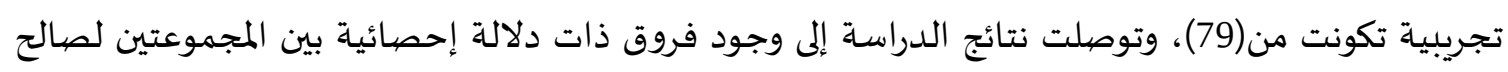
المجموعة التجريبية في التحصيل في مادة العلوم في كل مدرسة مما يشير إلى فعالية النموذج المقترح للتقويم من أجل تعلم العلوم. 
وقام البرصان وآخرون (2015) بإجراء دراسـة هدفت إلى التعرف على الممارسات التقويمية التكوينية

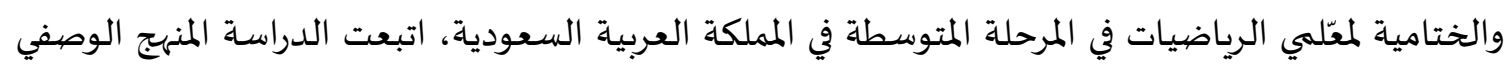

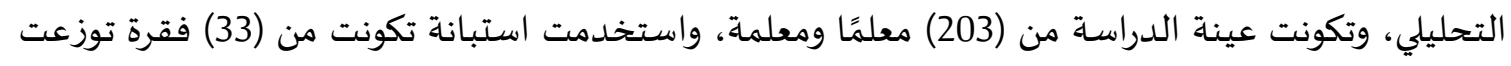

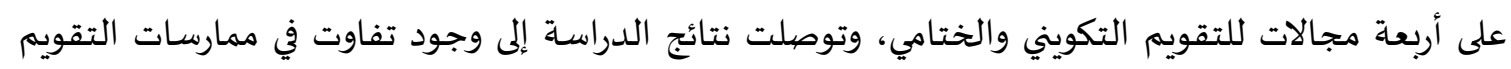

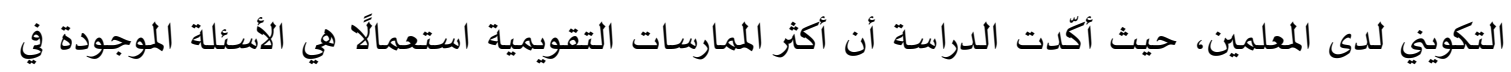

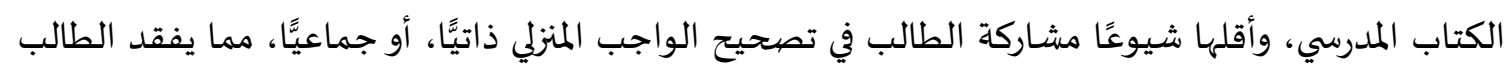
مهارة التقويم الذاتي. كما أجرى المزروع (2014) دراسة هدفت إلى الكشف عن واقع التقويم التكويني في تدريس العلوم في المرحلة

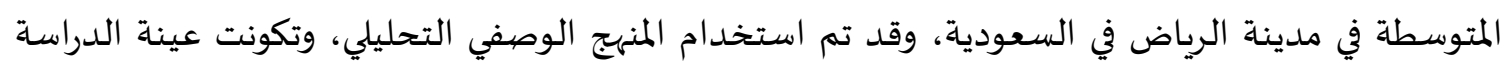

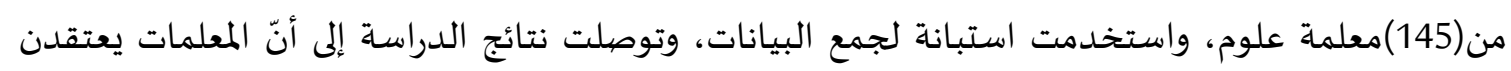

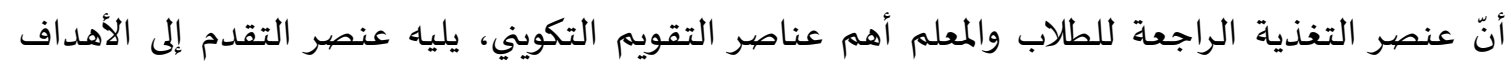

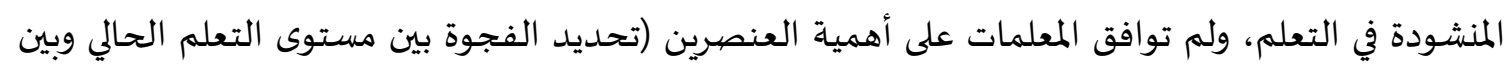

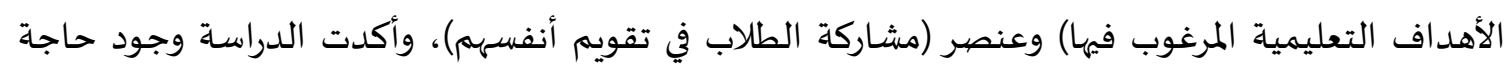
إلى تنمية وعي المعلّمات بالتقويم التكويني، وطريقة تطبيقها. دراسـة فولنت وبيكيت (Beckette \& Volante, 2011) والتي هدفت إلى الكشف عن المن الممارسات التقويمية

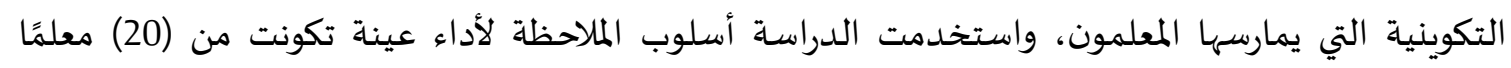

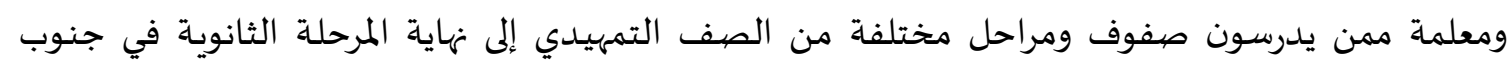

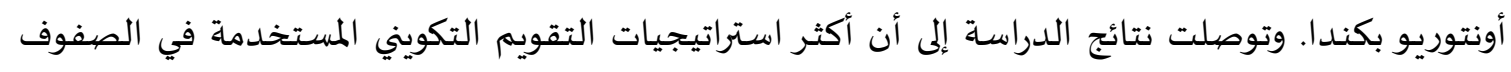

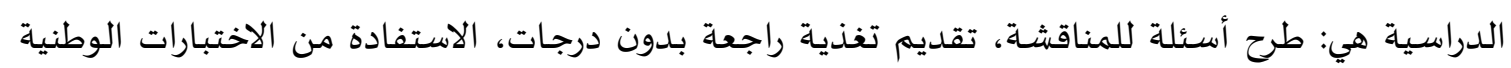
لتحسين التعلم. - أما دراسة سليمان (2007) فهدفت إلى التعرف على مستوى معرفة معلمي العلوم في المرحلة الأساسية

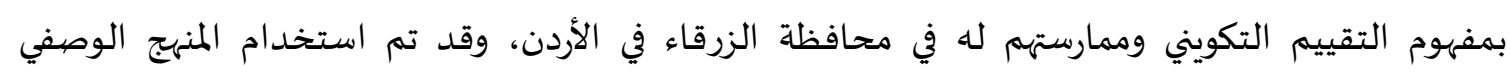

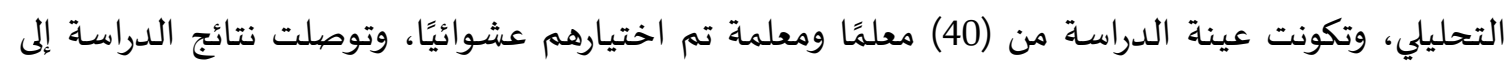

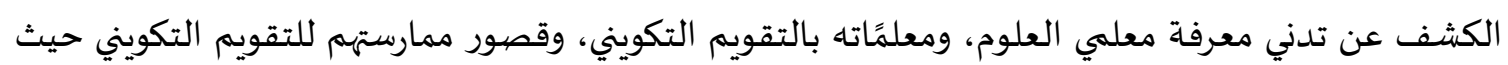

تراوحت بين متوسط وضعيف.

تعليق على الدراسـات السـابقة:

من خلال الاطلاع على الدراسات السابقة يمكن ملاحظة الأمور التالية:

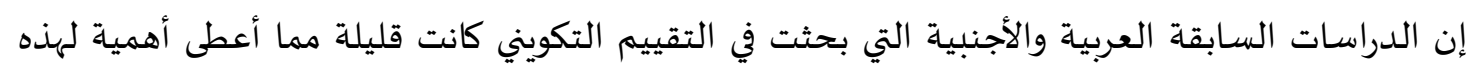
الدراسة وفتح الباب للباحثين في هذا المجال. وقد تم الاستفادة من الدراسات العربية والأجنبية السابقة من ناحية الإجراءات والأدوات والأسـاليب

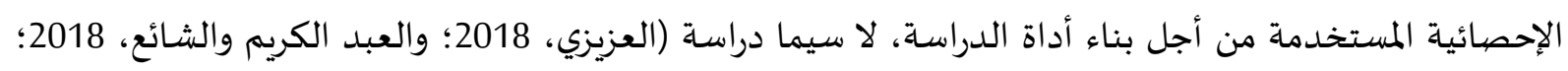

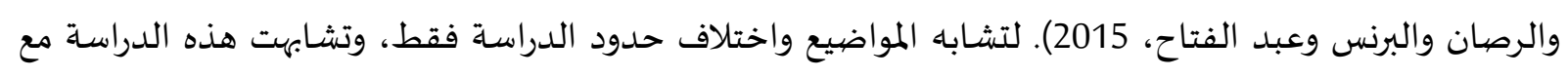

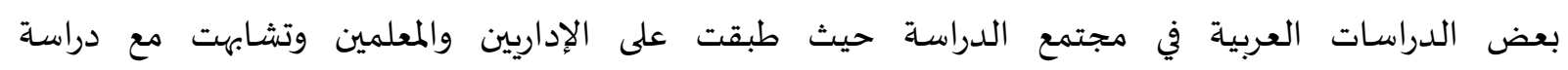
سليمان(2007)، كما وقد تشابهت بعض الدراسات مع هذه الدراسة في المنهج المستخدم وهو المنهج شبده التجريبي 
كدراسة العزيزي (2018)، في حين اختلفت مع دراسـة فولنت وبيكيت (Beckette \& Volante, 2011) التي استخدمت المنهج الوصفي التحليلي. ومن خلال ما سبق من استعراض للدراسات السابقة يتضح ندرة الدراسات التي استهدفت معلمي ومعلمًات العلوم، باستثناء دراسة سليمان (2007) التي استهدفت المرحلة المتوسطة، وطبقت في الأردن، ودراسة المزروبع (2014)، وطبقت في السعودية، وهي وتتشابه مع الدراسة الحالية في التعرف على مدى تطبيق معلمًات العلوم

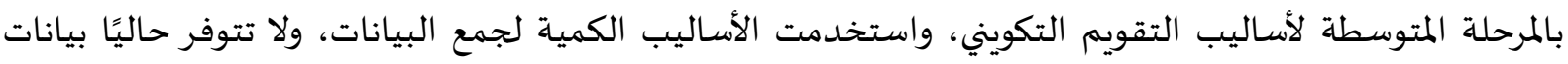

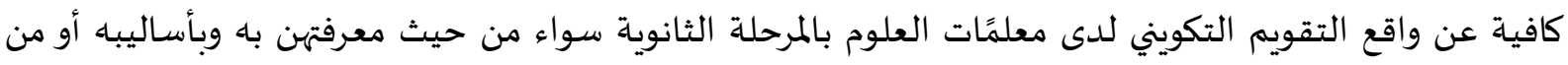

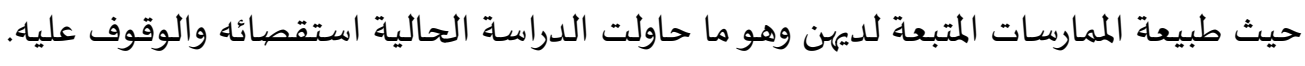

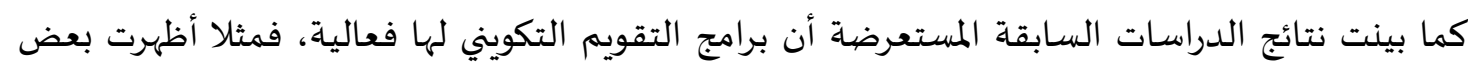

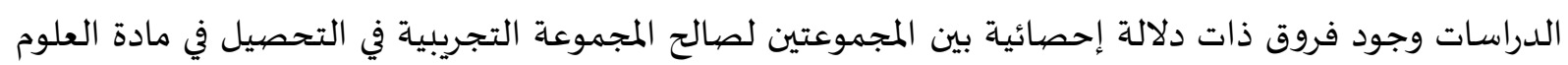
في كل مدرسة مما يشير إلى فعالية النموذج المقترح للتقويم من أجل تعلم إحمانية بين المجدوعتين العلوم.

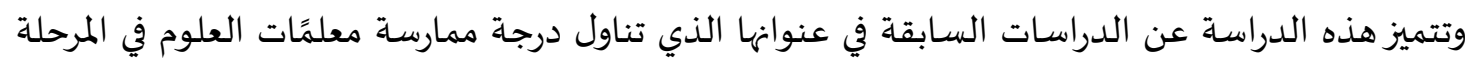

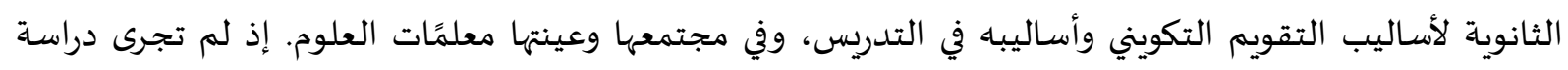
بحدود معرفة الباحثة المتواضعة على هذه العلاقة.

3- منهجية الدراسـة وإجراءاتها.

منهجية الدراسة لتحقيق أهداف هذه الدراسـة، اتبعت الباحثة المنهج الكيفي عن طريق استخدام بطاقة ملاحظة لممارسة معلمًات العلوم لأساليب التقويم التكويني.

مجتمع الدراسة: شمل مجتمع البحث جميع معلّمات العلوم الطبيعية في المرحلة الثانوية في المدارس الحكومية التابعة لإدارة

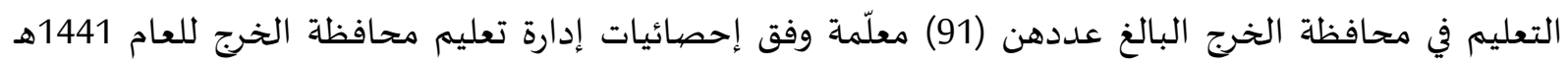

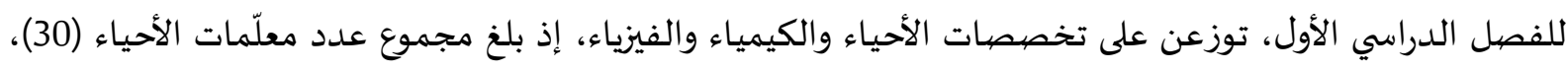
وعدد معلّمات الكيمياء (33)، وعدد معلّمات الفيزياء (28). الجدول (1): توزيع أفراد مجتمع الدراسة وفئاء التهق التخصص

\begin{tabular}{|c|c|c|c|}
\hline النسبة & ا ل العدد & المؤهل & التخصص \\
\hline- & 8 & بكالوريوس غير تربوي & أحياء \\
\hline- & 22 & بكالوريوس تربوي & أحياء \\
\hline$\% 33$ & 30 & & 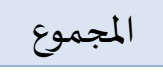 \\
\hline- & 7 & بكالوريوس تربوي & كيمياء \\
\hline- & 26 & بكالوريوس كيمياء ودبلوم تربوي & كيمياء \\
\hline$\% 36$ & 33 & & المجموع \\
\hline- & 4 & بكالوريوس تربوي & فيزياء \\
\hline
\end{tabular}


المجلة العربية للطوم ونثر الأبحاث ـ مجلة العلوم التربوية والنفسية ـ المجلد الساس ـ العلد العاثر ـ فبراير 2022م

\begin{tabular}{|c|c|c|c|}
\hline النسبة & العدد & المؤهل & التخصص \\
\hline- & 24 & بكالوريوس تربوي & فيزياء \\
\hline$\% 31$ & 28 & & المجموع \\
\hline$\% 100$ & 91 & & الكلي \\
\hline
\end{tabular}

عينة الدراسـة:

شملت عينة الدراسة على (6) معلمًات تم اختيارهن بطريقة عشوائية حيث تم تصنيف المعلمًات حسب المباء التخصص (كيمياء، فيزياء، أحياء). ومن ثم اختيار معلمتين من كل تخصص بطريقة عشوائية؛ لتطبيق سلم التقدير

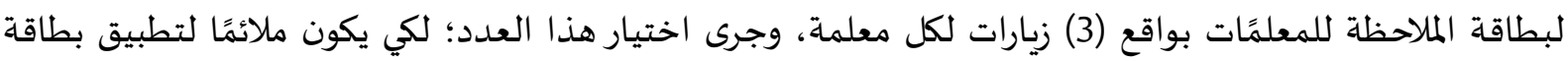
الملاحظة التي تتطلب جهدًا لجمع البيانات. ويوضح الجدول (1) التخصص والخبرة والدرجة العلمية والمؤهل التربوي لعينة بطاقة الملاحظة. الجدول (2): وصف عينة بطاقة الملاحظة من المعلمًات الست وفق التخصص والخبرة والدرجة العلمية والمؤهل

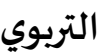

\begin{tabular}{|c|c|c|c|}
\hline سنوات الخـدمة & المؤهل & التخصيص & اسم المشـاركة \\
\hline 11 & بكالوريوس غير تربوي & أحياء & 1 \\
\hline 9 & بكالوريوس تربوي & 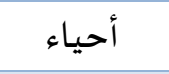 & 2 \\
\hline 4 & بكالوريوس تربوي & كيمياء & 3 \\
\hline 9 & بكالوريوس كيمياء ودبلوم تربوي & كيمياء & 4 \\
\hline 14 & بكالوريوس تربوي & فيزياء & 5 \\
\hline 13 & بكالوريوس تربوي & فيزياء & 6 \\
\hline
\end{tabular}

أداة الدراسة (بطاقة الملاحظة):

للإجابة عن سؤال الدراسة، تم إعداد سلم التقدير اللفظي لبطاقة الملاحظة اشتمل على ستة أساليب

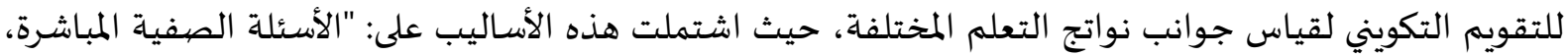

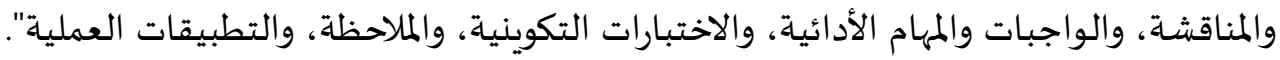

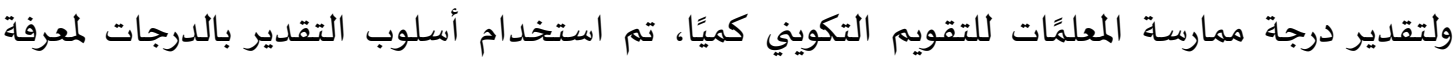

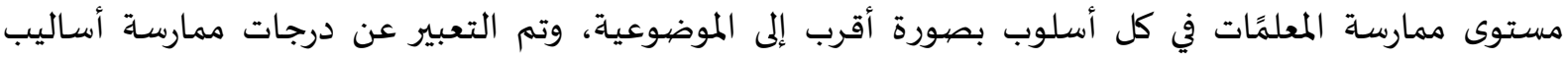

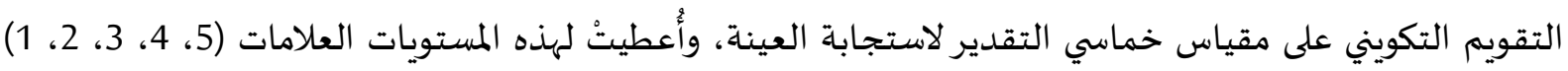

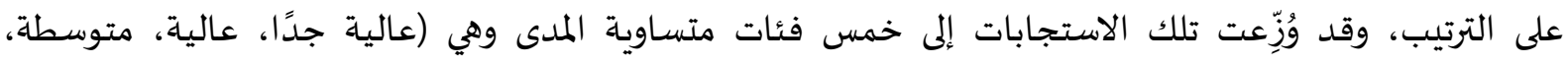
منخفضـة جدًا، منخفضة) إذ تدلُّ خمسة على وجود ممارسات كاملة لأساليب التقويم التكويني، بينما يشير الواحد

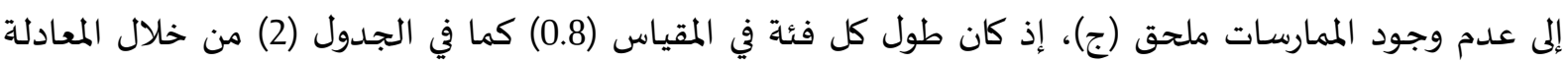

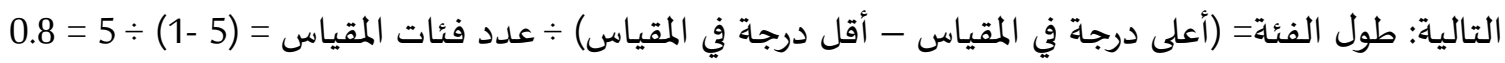
الجدول (3): مقياس تفسير نتائج بطاقة الملاحظة

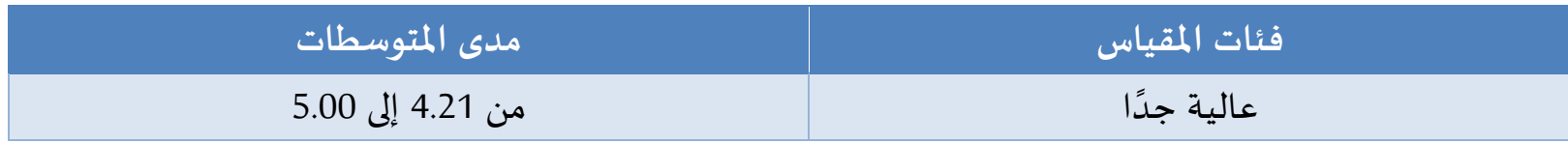




\begin{tabular}{|c|c|}
\hline مدى المتوسطات & فئات المقياس \\
\hline من 3.41 إلى أقل من 4.20 & عالية \\
\hline من 2.61 إلى أقل 3.40 & متوسطة \\
\hline من 1.81 إلى أقل 2.60 & منخفضية \\
\hline من 1 إلى أقل من 1.80 & منخفضية جدًا \\
\hline
\end{tabular}

صدق سلم التقدير اللفظي لبطاقة الملاحظة

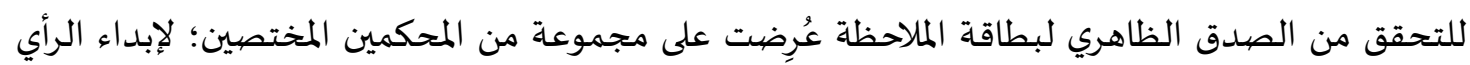

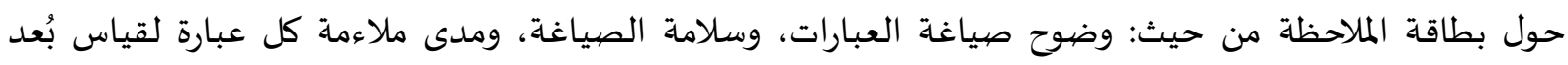

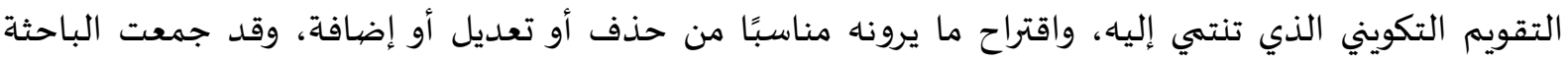

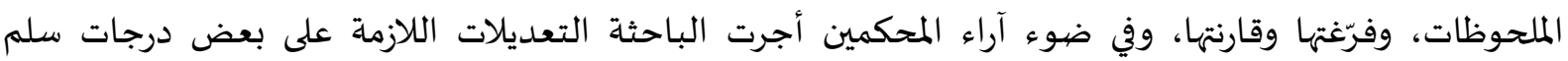

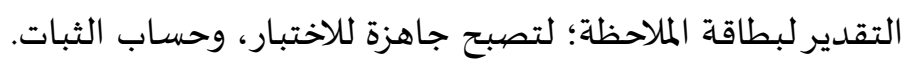

ثبات سلم التقدير اللفظي لبطاقة الملاحظة استخدمت الدراسة بطاقة ملاحظة، وهي عبارة عن استمارة لتسجيل البيانات للاستعانة بها عند تحليل

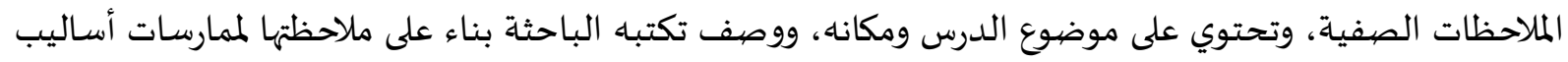

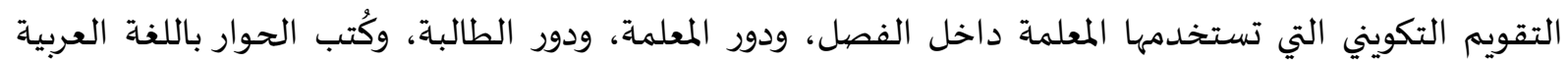

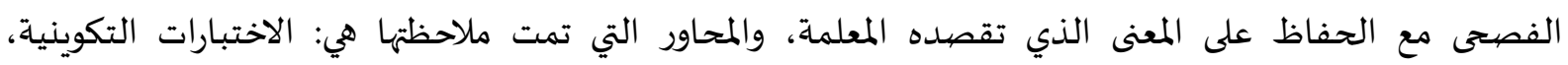

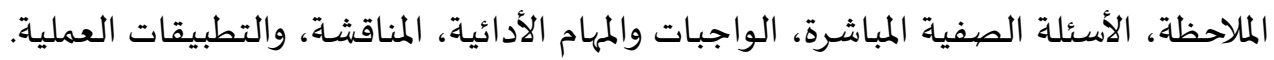

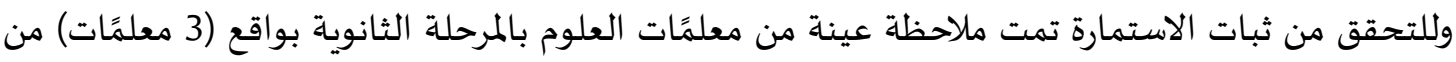

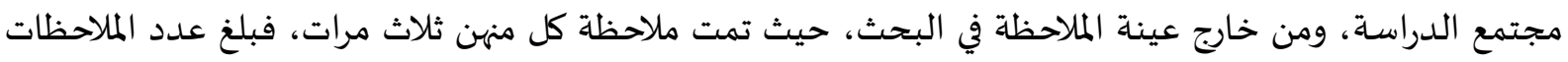
(18) ملاحظة، و (9) ملاحظات من الباحثة، و(9) ملاحظات من ملاحظة متعاونة تحمل درجة الماجستير في المناهج

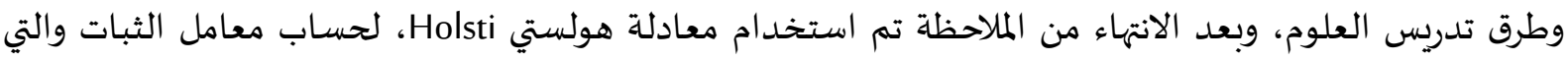
تنص على: نسبة الاتفاق = (عدد مرات الاتفاق بين الملاحظين × 2) / عدد ملاحظات الملاحظ الأول + عدد ملاحظات

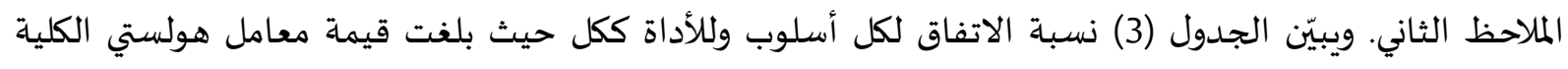

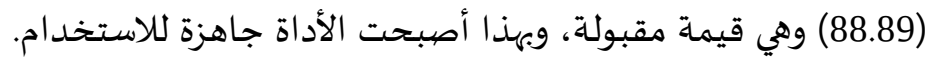
الجدول (4): وحدات الاتفاق والاختلاف ونسبة الثبات بين الملاحظتين

\begin{tabular}{|c|c|c|c|c|c|c|c|}
\hline \multirow{2}{*}{ نسبة الاتفاق } & \multirow{2}{*}{ وحدات الاختلاف } & \multirow{2}{*}{ وحدات الاتفات } & \multicolumn{3}{|c|}{ الاتفاق لكل معلمة } & \multirow{2}{*}{ الملاحظات } & \multirow{2}{*}{ الممارسة } \\
\hline & & & 3 & 2 & م & & \\
\hline$\% 77.8$ & 2 & 7 & 2 & 2 & 3 & 9 & أسلوب الأسئلة الصفية المباشرة \\
\hline$\% 88.9$ & 1 & 8 & 3 & 2 & 3 & 9 & أسلوب المناقشـة \\
\hline$\% 77.8$ & 2 & 7 & 2 & 3 & 2 & 9 & الواجبات والمهام الأدائية \\
\hline$\% 88.9$ & 1 & 8 & 3 & 3 & 2 & 9 & الاختبارات التكوينية \\
\hline$\% 100$ & $\mathbf{0}$ & 9 & 3 & 3 & 3 & 9 & الملاحظة \\
\hline$\% 100$ & $\mathbf{0}$ & 9 & 3 & 3 & 3 & 9 & التطبيقات العملية \\
\hline
\end{tabular}


م1= المعلمة الأولى. م2= المعلمة الثانية. م3= المعلمة الثالثة.

$$
\text { تحليل البيانات النوعية }
$$

فرّغت الباحثة الحصص بكتابتها، وميَّزت الملفات المفرغة لكل معلمة مع إرفاق البيانات الخاصة بكل حصية مثل اليوم والتارتخ والتوقيت، والتخصص العلمي (أحياء، فيزياء، كيمياء)، وعنوان الدرس والوحدة التئه التي ينتمي إليها،

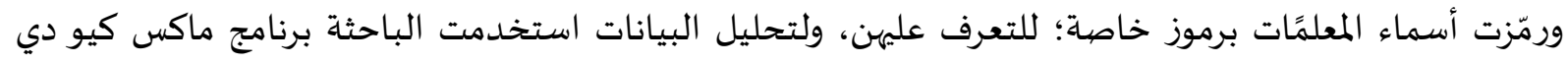

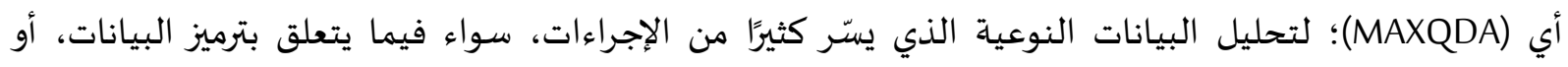

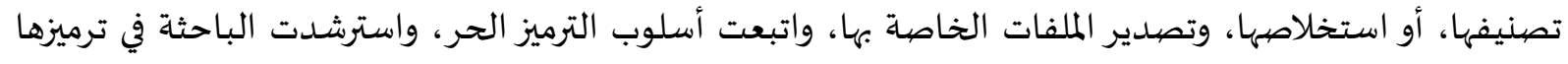

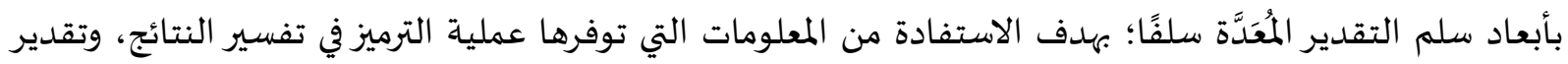

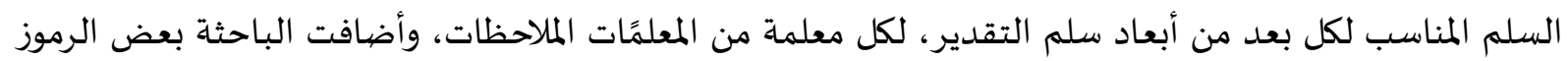
المستحدثة التي رأت لها أهمية في فهم أعمق لممارسات التقويم التكويني.

إجراءات الدراسة

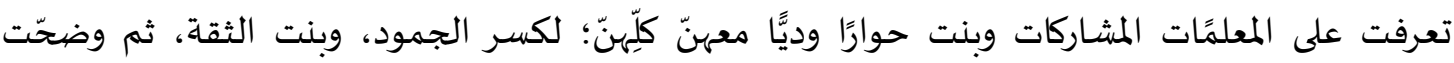

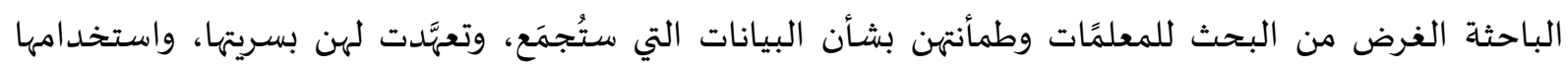

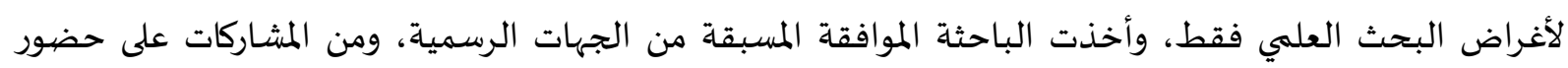

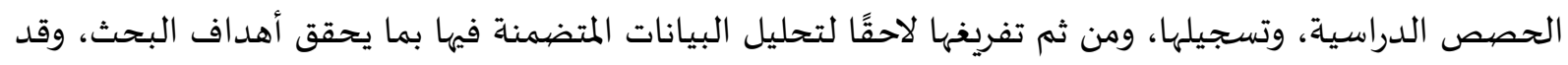

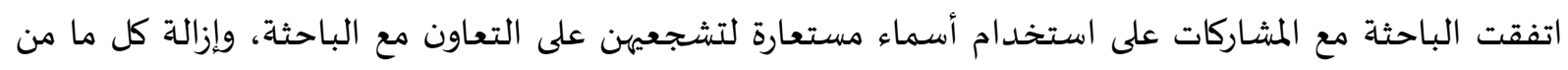

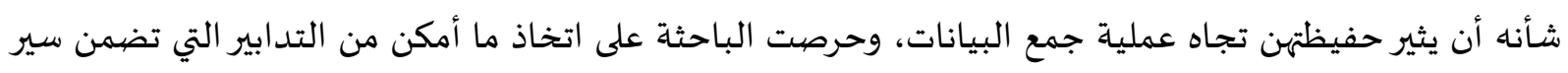

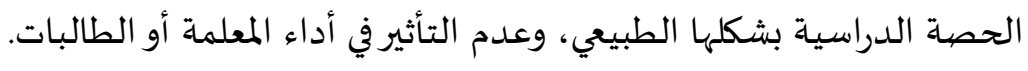

$$
\text { الأسـاليب الإحصيائية: }
$$

- المتوسطات الحسابية، والانحرافات المعيارية؛ للتعرف إلى مستوى ممارسة معلمًات العلوم في المرحلة الثانوية

$$
\text { لأسساليب التقويم التكويني. }
$$

- - معامل ارتباط بيرسون لحساب الصيدق الداخلي للاستبانة.

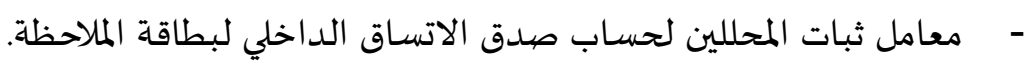

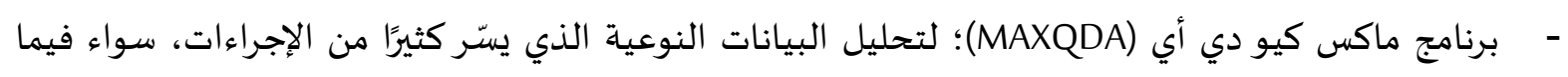
يتعلق بترميز البيانات، أو تصنيفها، أو استخلاصيها. - معادلة هولستي لقياس ثبات محكات بطاقة الملاحظة. 
نتائج سؤال الدراسة: "ما درجة ممارسة معلمًات العلوم في المرحلة الثانوية لأساليب التقويم التكويني

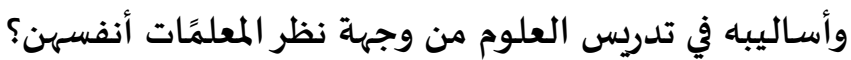
وللإجابة عن هذا السؤال لاحظت الباحثتان (6) معلمًات بواقع ثلاث حصص دراسية لكل معلمة، وسجّلت الحصص صوتيًا، وفرَّغتها، واستخدمت الملفات المفرغة لكل حصة دراسية مادة للتحليل باستخدام برنامج ماكس كيو دي أي MAXQDA؛ لترميز البيانات، وتحليلها، وبدراسة الرموز قدَّرت الباحثة درجة كل ممارسة من ممارسات التقويم التكويني، استنادًا إلى سلم التقدير، ويبين الجدول التالي متوسط ممارسات المعلمًات لكل مجال من مجالات سلم التقدير، والمستوى الإجمالي للممارسات. والجدول (5) يبين ممارسات المعلمًات لأساليب التقويم التكويني.

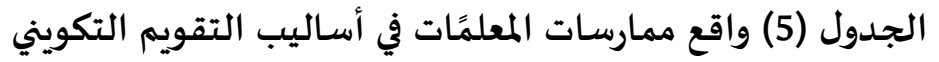

\begin{tabular}{|c|c|c|c|c|}
\hline درجة الممارسة & الترتيب & الانحراف المعياري & المتوسط & سلم التقدير \\
\hline متوسط & 2 & 0.52 & 3.3 & الأسئلة الصفية \\
\hline 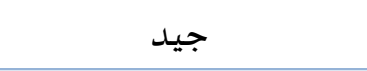 & 1 & 0.52 & 3.7 & أسلوب المناقشـة \\
\hline ضعيف & 3 & 1.55 & 2.0 & الواجبات والمهام الأدائية \\
\hline ضيف & 4 & 1.64 & 1.5 & الاختبارات التكوينية \\
\hline ضعيف جدًَا (غير متوفر) & 6 & 0 & 0 & الملاحظة \\
\hline ضعيف & 5 & 1.63 & 0.7 & التطبيقات العملية \\
\hline ضيف & & 0.68 & 1.86 & ممارسات التقويم الكلية \\
\hline
\end{tabular}

يتبين من الجدول (5) أن متوسط ممارسات المعلمًات لأساليب التقويم التكويني بلغ (1.86)، وبدرجة

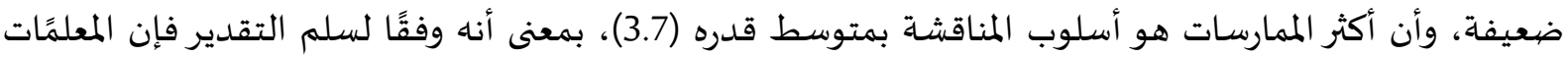

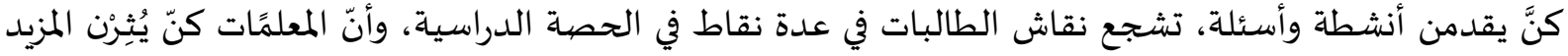

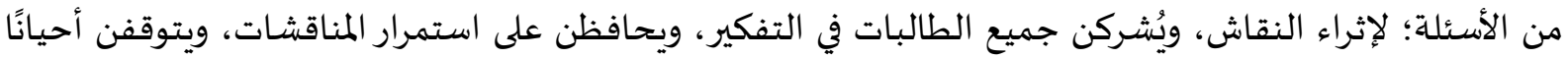

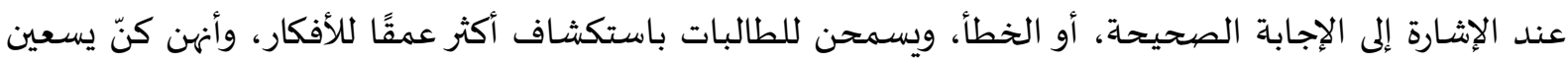
لمعرفة العديد من وجهات نظر الطالبات.

وجاءت ممارسات الأسئلة الصفية في الترتيب الثاني بعد المناقشة بمتوسط قدره (3.3)، وهذه القيمة تعني

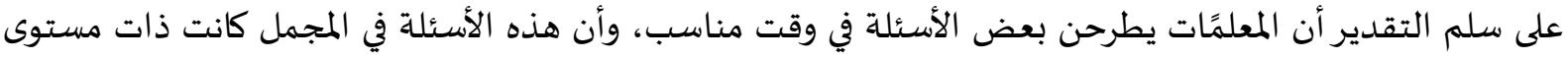

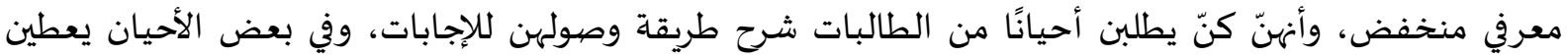

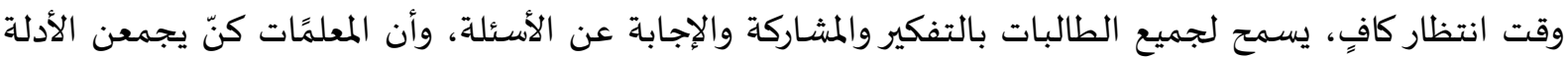
من عدد قليل من الطالبات، مما يضيع العديد من الفرص المسـاعدة في تحديد مستوى تقدمهن. وتتفق هذه النتائج

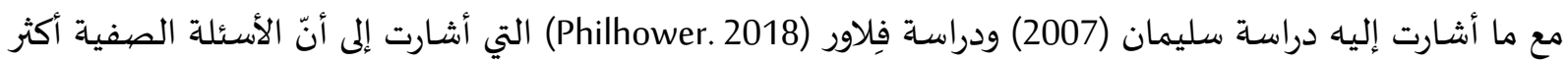
الممارسات شيوعًا بين المعلمين.

وجاء أسلوب الواجبات والمهام الأدائية في الترتيب الثالث بمتوسط مقداره (2.0)، وهو مستوى متدن نسبيَّا،

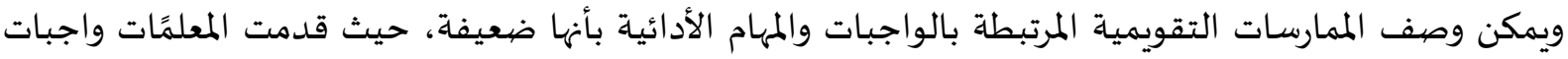

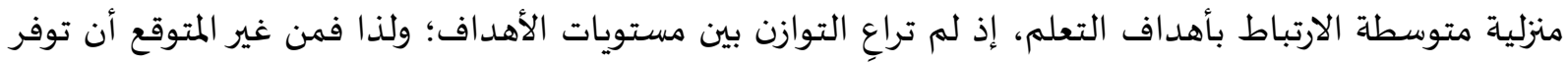


أدلة عن مدى تقدم الطالبات من خلال هذه الواجبات، أو المهام الأدائية، أو أن مجموعة الأدلة قليلة ولا يمكن

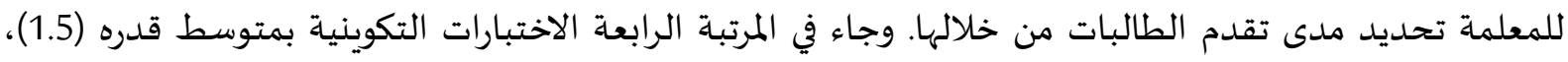

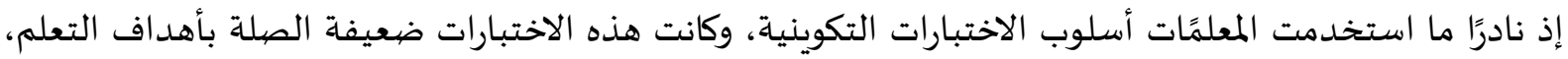

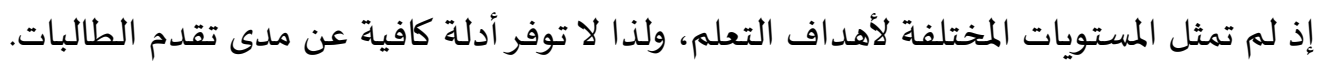

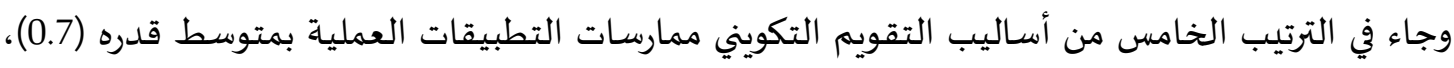

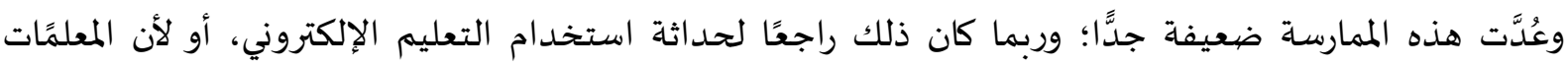

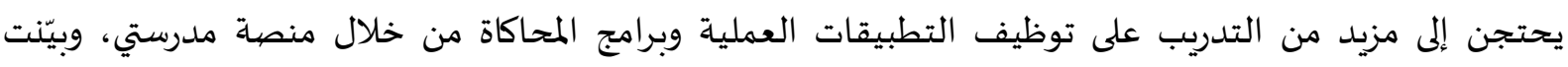

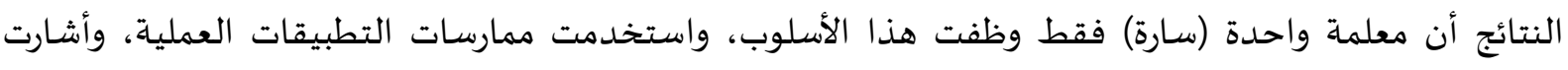

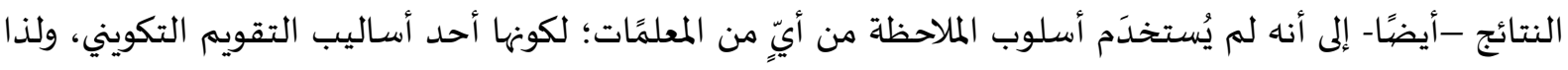

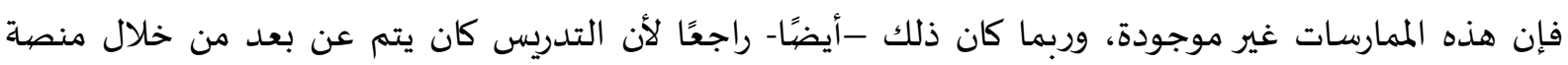

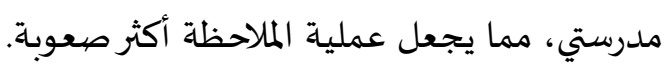

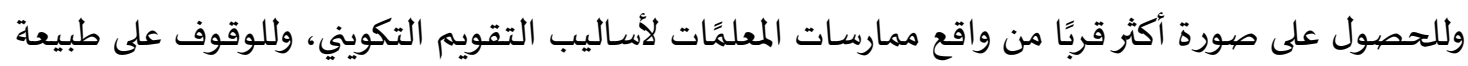

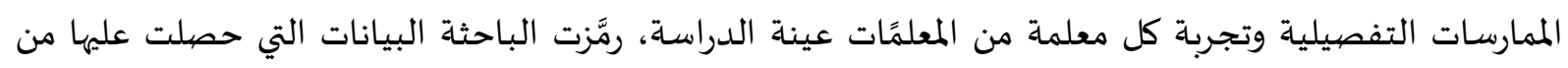

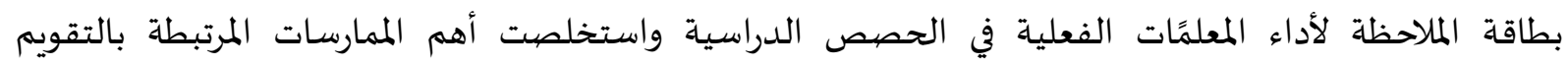

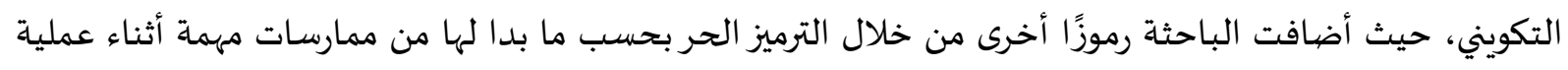

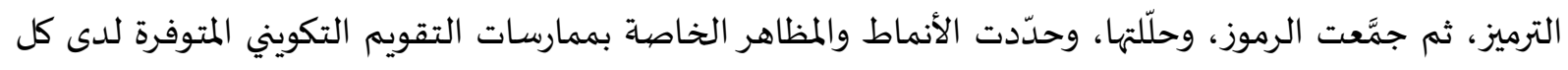

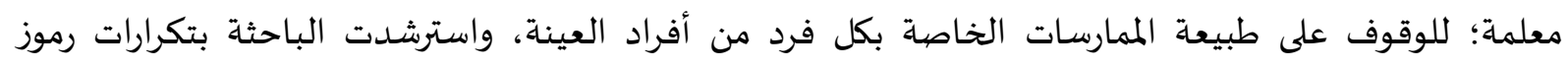

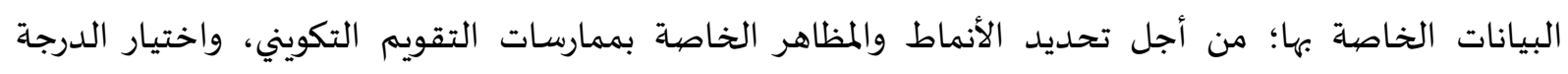

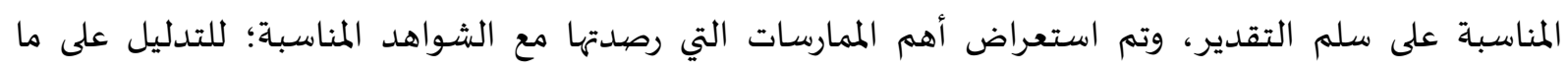

استخلصتاء من عملية التحليل. وركزت عملية التحليل على الممارسات التقويمية ووُجهت بغرض الإجابة عن سؤالَي البحث: الثاني والثالث

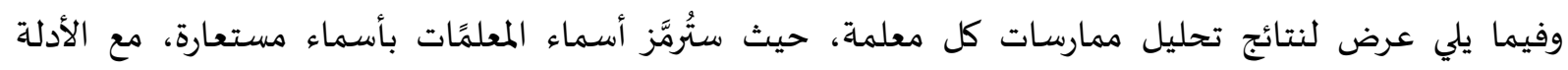

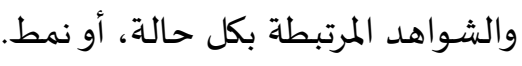

أولا: المعلمة (1)

لاحظت الباحثة أداء المعلمة "منيرة" في ثلاث حصص دراسية، وتبيّن أن المعلمة نوّعت من استخداماتها

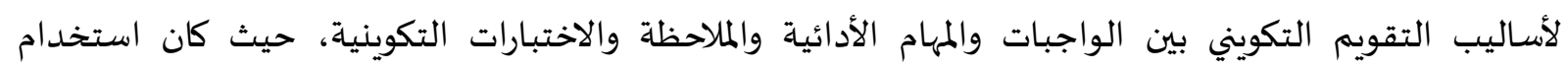

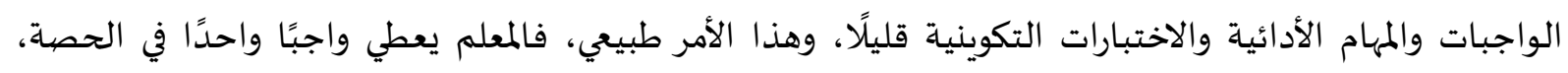

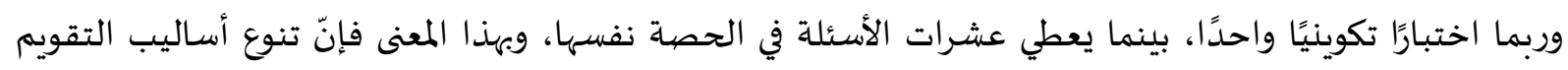

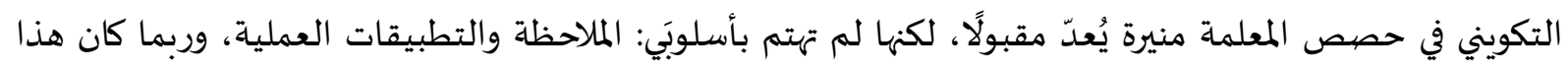

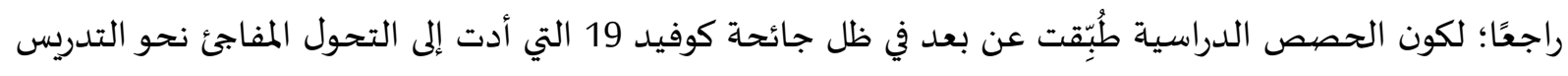

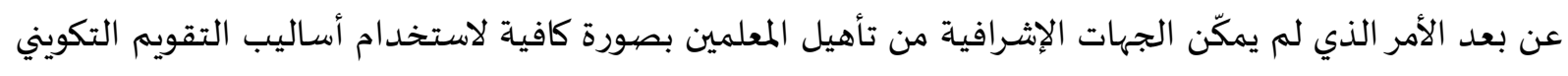

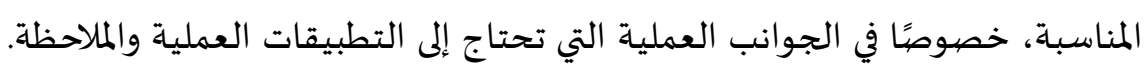

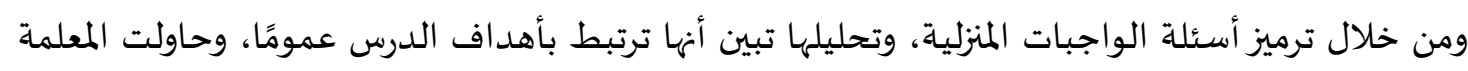

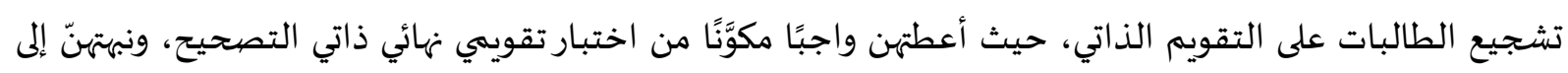


ضرورة تقويم أنفسهن ذاتيًا، وأرسلت -بعد الانتهاء من الدرس- رابطًا، فيه سؤال عن مريع بانيت، وطلبت من

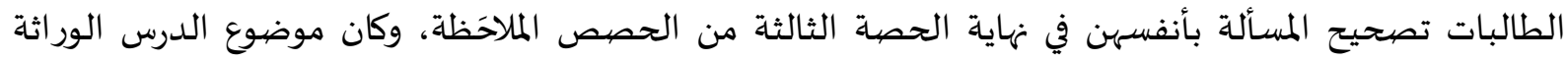

وتبين أن المعلمة (1) استخدمت في الحصة الدراسية عددًا كبيرًا من الأسئلة الصفية، ولكن الباحثة

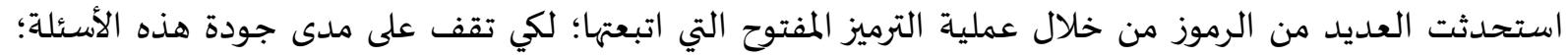

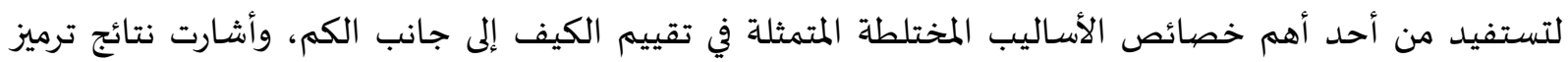

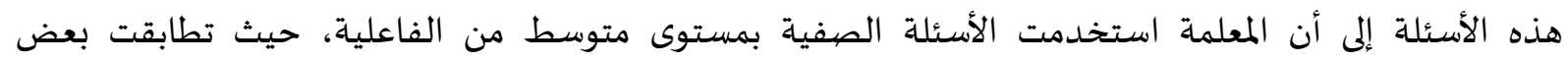

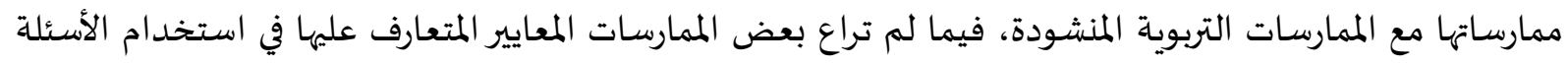

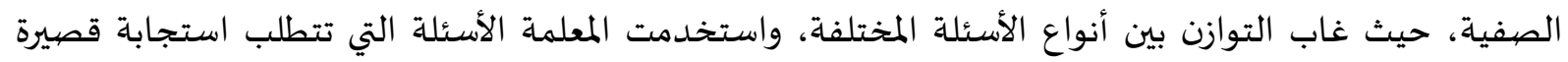

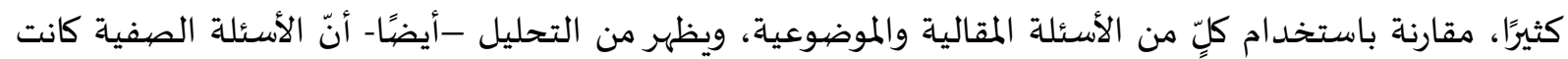
في الغالب لا تراعي معايير الصياغة الجيدة، ولعل هذا من الأسباب التي حدّت من مستويات من منئ التفكير التي تتطلبها

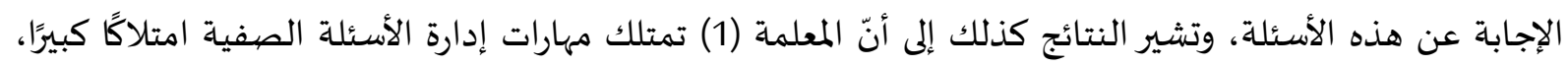

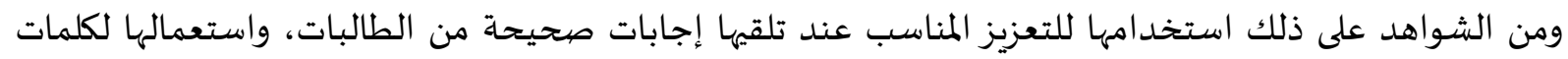

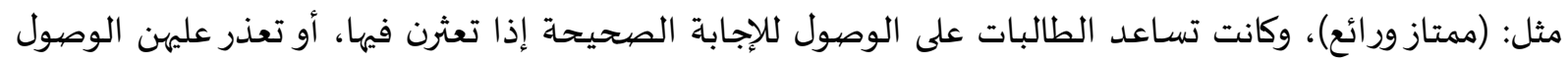

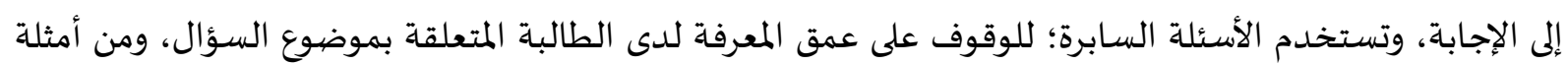

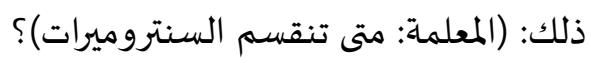
الطالبة: الطور الانفصالي الثاني.

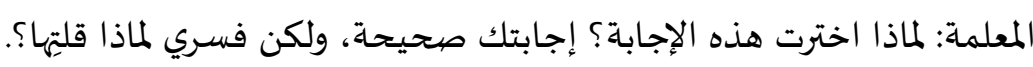

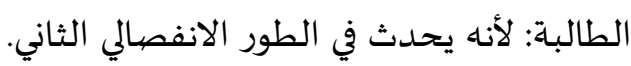

المعلمة: ممتاز القطع المركزية تنقسم في الطور الانفصالي الثاني، (برافو) يا عهود).

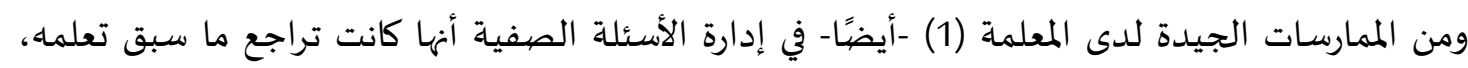

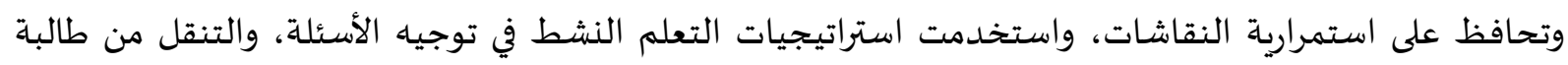
لأخرى، ومن الشواهد على ذلك: بدأت المعلمة (1) في تطبيق استراتيجية (من أنا)، إذ اختارت المعلمة الطالبات بشكل عشوائي للمشاركة في

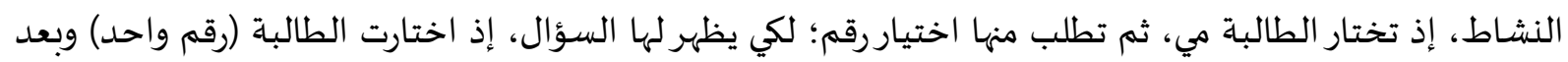

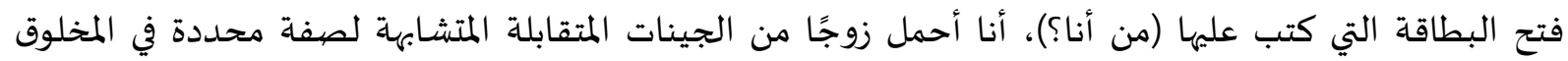
الحي؟ ويمكن القول إجمالًا: إنّ المعلمة (1) لم تعطِ وقتَ انتظار كافيًا بعد طرح الأسئلة الصفية، ولم يظهر التدرج

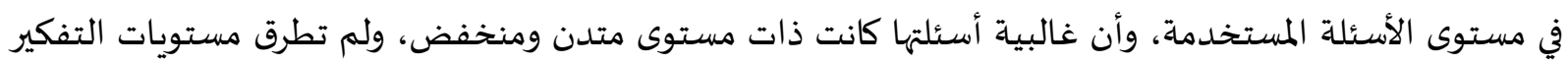

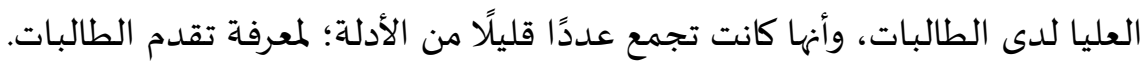

ثانيًا: المعلمة (2)

لاحظت الباحثة أداء المعلمة (2) في ثلاث حصص دراسية، سجلتها صوتيًا، ثم فرّغتها ورمَّزتها باستخدام برنامج ماكس كيو دي أي (MAXQDA)، واتضح أن المعلمة لم تنوع في استخدام أساليب التقويم التكويني، وأهنا ركزت على الأسئلة الصفية، بينما أغفلت بقية أساليب التقويم التكويني، إذ لم تلتوفر الملاحظة، ولانية الاختبارات 


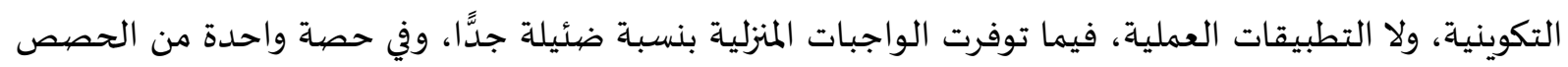

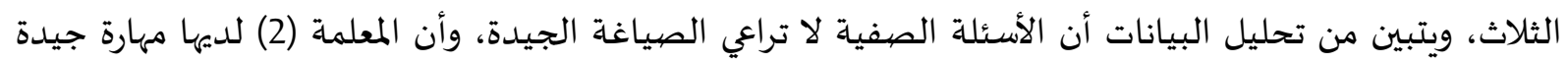

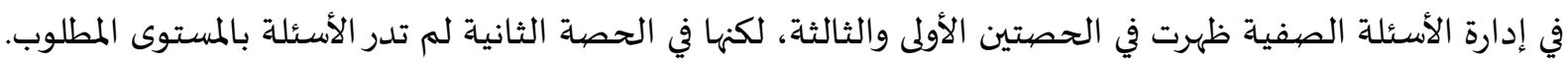

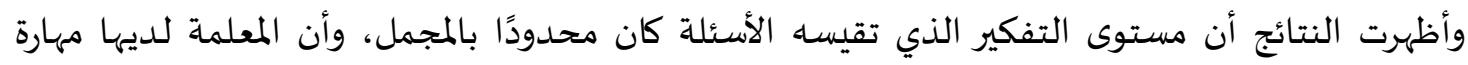

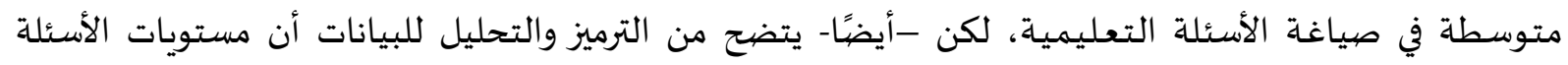
الصفية التي استخدمتها المعلمة (2) كانت ذات مستويات تفكير محدودة، وأن مهارتها في صياغة الأسئلة تحتاج إلى الى لئيل

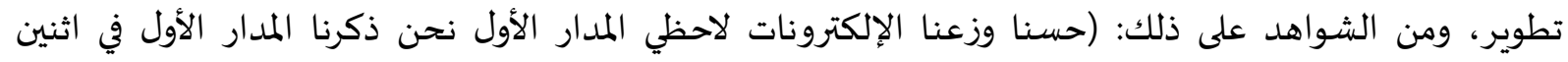

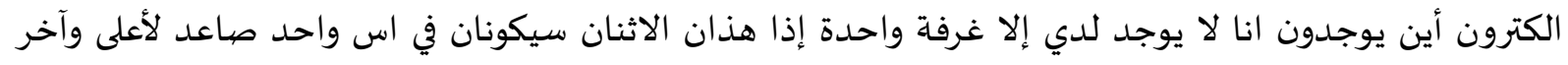

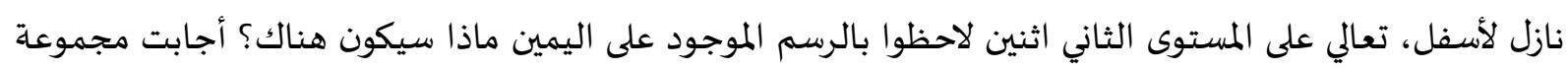

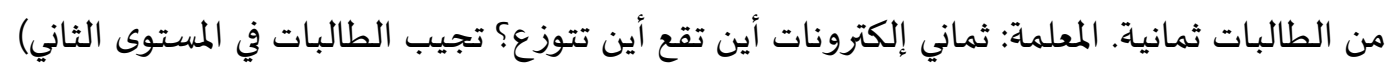

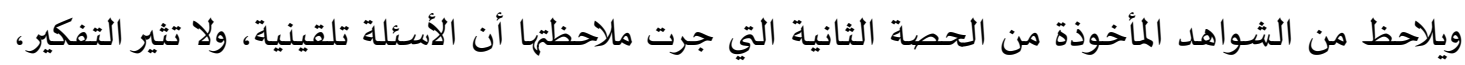

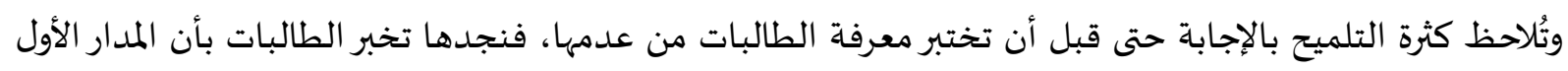

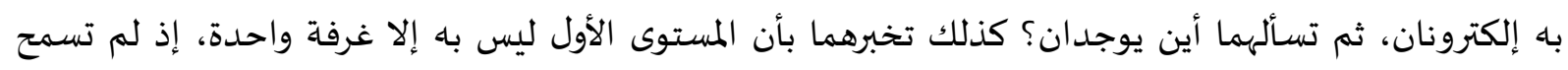

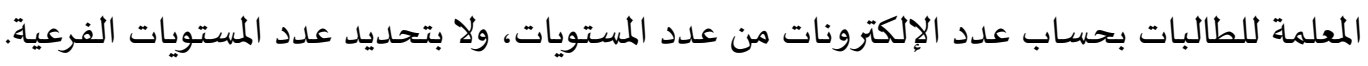

ثالثًا: المعلمة (3)

بعد ملاحظة الحصص الدراسية الخاصة بالمعلمة (3)، تبيّن أن المعلمة تركز في تدريسها على الأسئلة

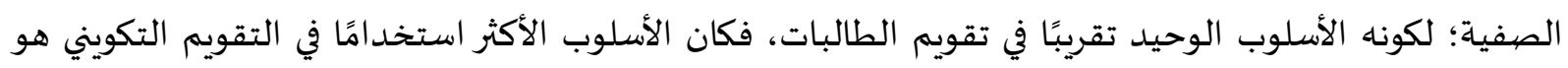

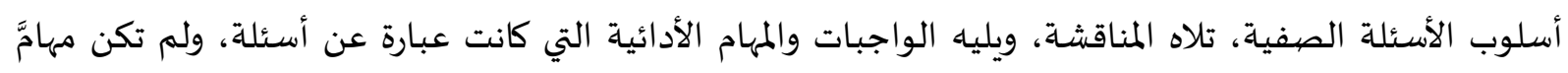

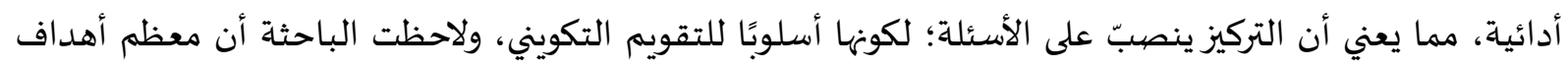

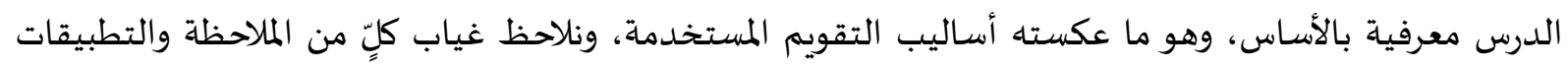

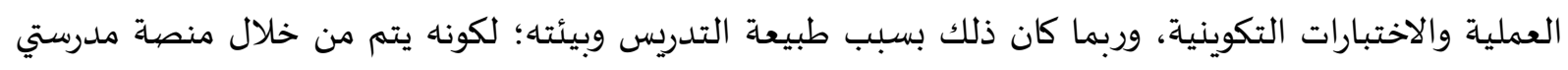

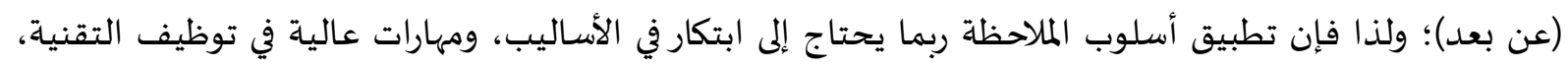
وتصيميم الأنشطة ومقاييس الملاحظة المتعلقة بها. ولأن الأسئلة الصفية والمناقشة مثّلا الأسلوبين الأكثر شيوعًا بين الأساليب الأخرى تعرض الباحثة الماحثة تحليلًا

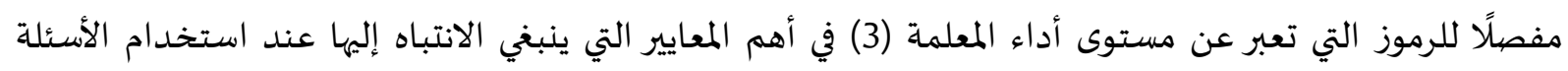
الصفية والمناقشة في الغرفة الصفية. وظهر من التحليل أن غالبية الأسئلة الصفية كانت إنشائية قصيرة الاستجابة، يليها الأسئلة الموضيوعية، ثم

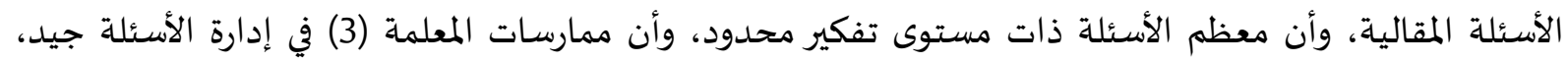

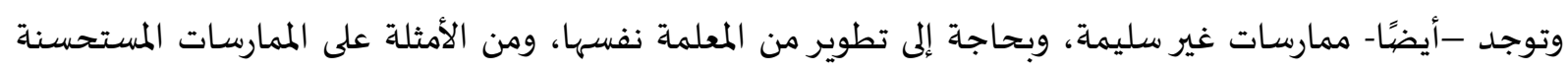

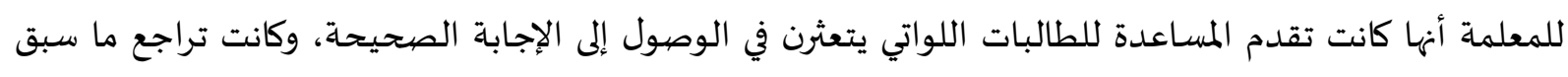

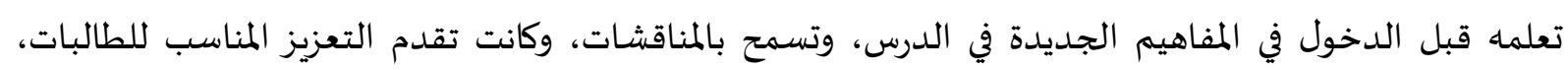

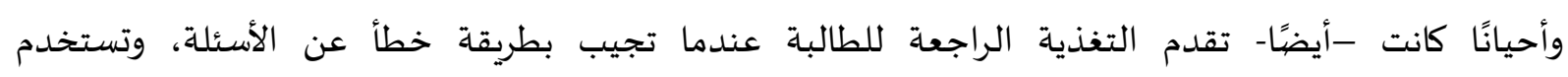
الاستراتيجيات الجذابة في طرح الأسئلة، ومن الشواهد على ذلك إعطاؤها ورقة عمل للطاتلة لطالبات في نهاية الحصة 
الأولى، ثم تشغيل مؤقت لحساب الوقت المستغرق في الحل، وتحديد الطالبات اللواتي ينجزن المهام المطلوبة في ورقة

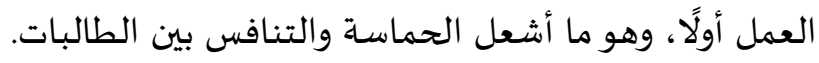

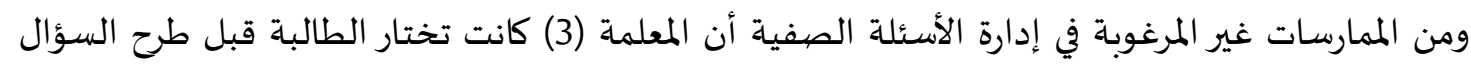

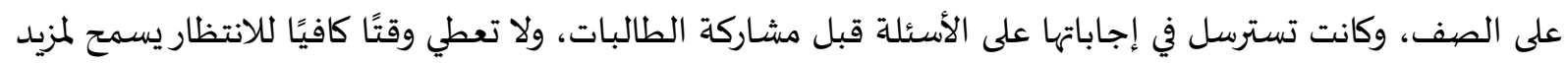

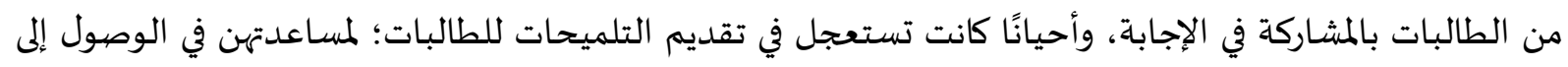

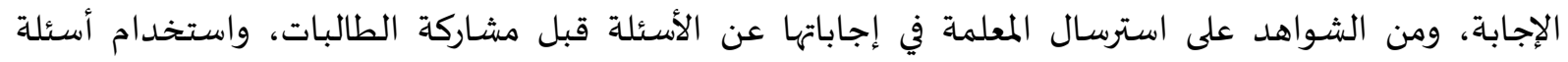

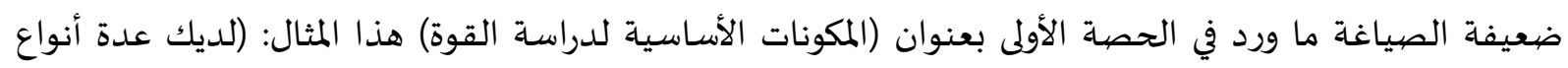
من القوى من خلال هذه القوى أريد أن أعمل على تمثيل مخطط حركة، لنرسم المخطط نلاحظ فران رسم بجانب هذا

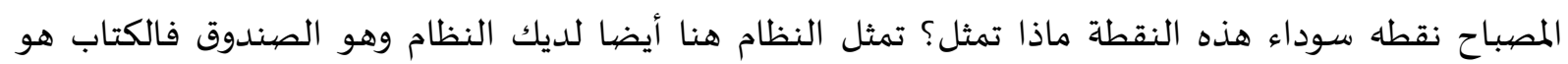

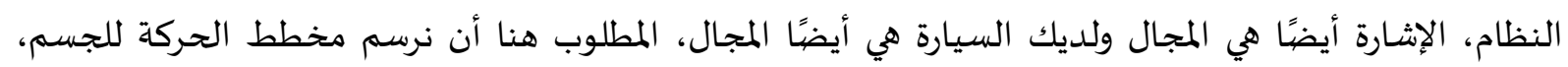

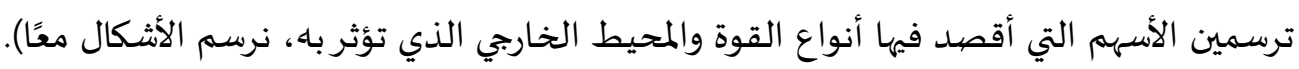

رابعًا: المعلمة (4)

بعد ملاحظة الحصص الدراسية الخاصة بالمعلمة (4)، وتبيّن أنّ المعلمة تركّز في تدريسها على أسلوبَي:

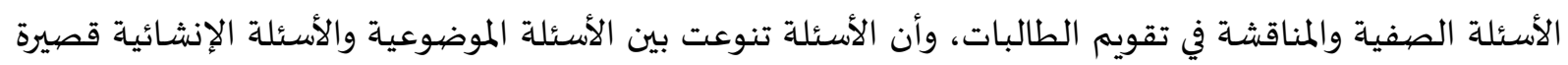

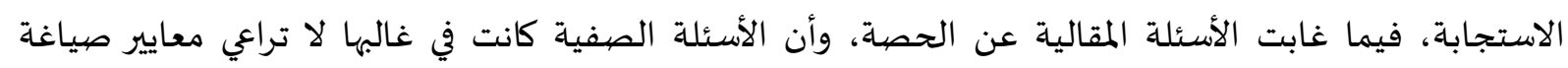

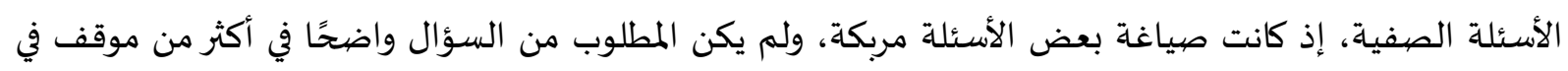

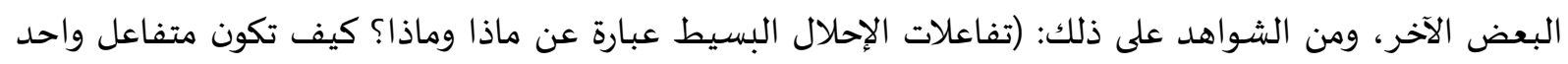

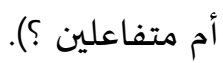
ومن الشواهد أيضًا: (لو أتينا للفلور والأكثر نشاطا والكلور أقل منه والبروم أقل واليود الأقل، حسنا بالنسبة للفلور من يستطيع ان يحل محله). ويلاحظ أن نسبة كبيرة من الأسئلة الصفية المستخدمة ذات اندات مستوى تفكير محدود، وربما يرتبط هذا بقلة

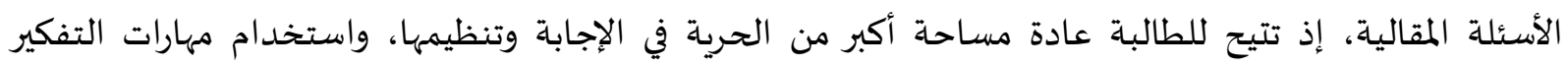

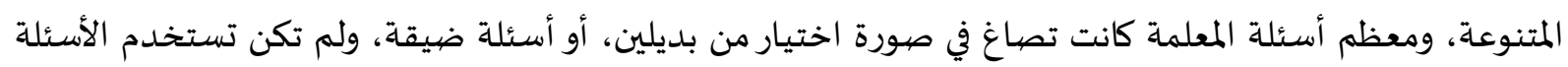
الموسعة (المفتوحة) تقريبًا. ومن حيث إدارة الأسئلة الصفية فقد كانت المعلمة (4) تراجع ما سبق تعلمهاه، وتساعد الطالبات في الوصول

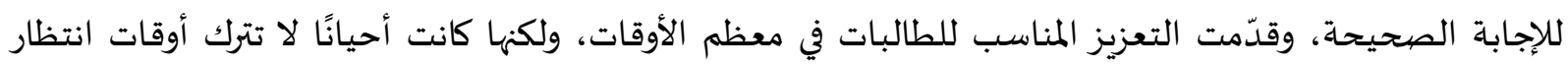

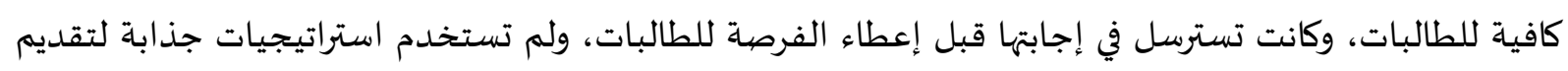

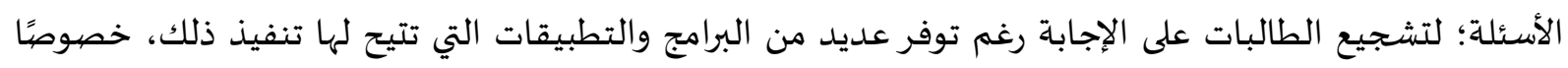
أن الحصة الدراسية كانت تنفذ من خلال منصية مدرستي.

خامسًا: المعلمة (5) أظهر التحليل لأنواع أساليب التقويم المتبعة من المعلمة (5) في الحصص الثلاثة أهها اقتصرت على أسلوبين

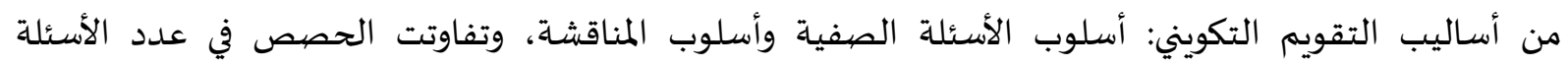

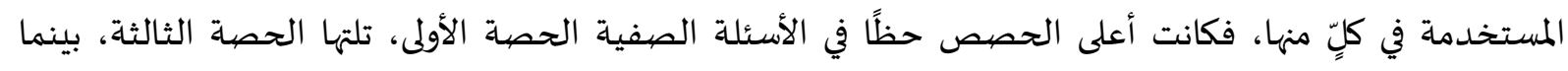

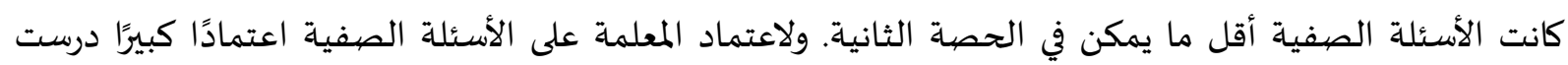


الباحثة طبيعة الأسئلة الصفية دراسة تفصيلية، إذ أظهر ترميز البيانات، وتحليلها تنوع الأسئلة التي استخدمتها

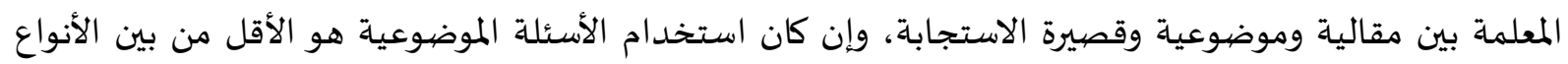

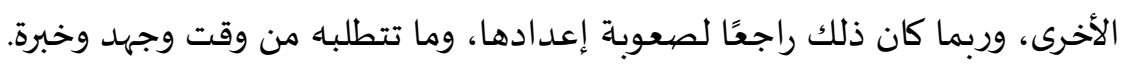

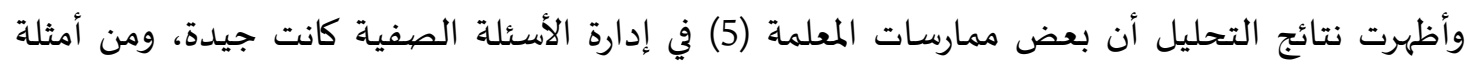
ذلك إعطاء وقت كاف للانتظار بعد طرح السؤال على الطالبات، ومساعدة الطالبات على الوصول للإجابة، وإعطاء

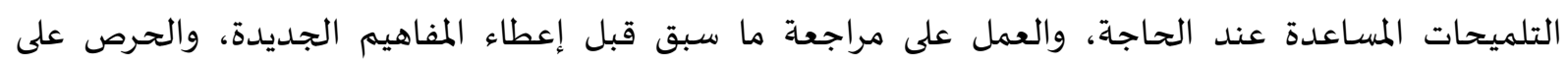

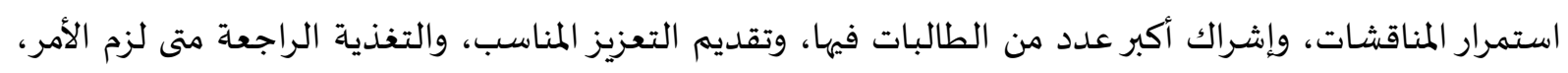

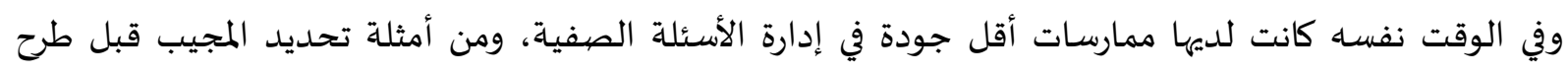

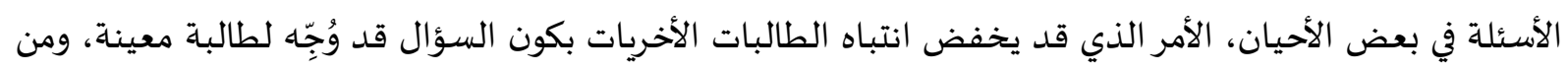

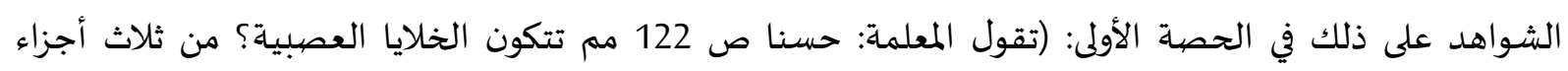
تفضلي يا سارة).

ويتضح من سرد الحوار وطرح الأسئلة بأنها حددت الطالبة مباشرة بعد طرح السؤال، ولم تعط الفرصة

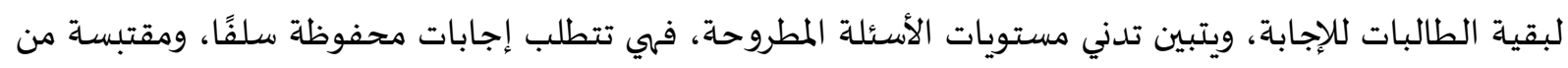

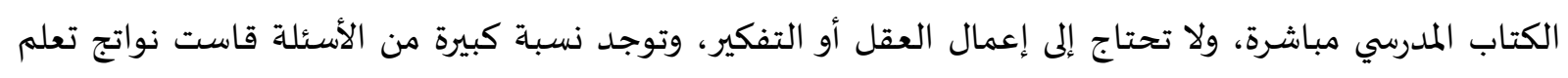

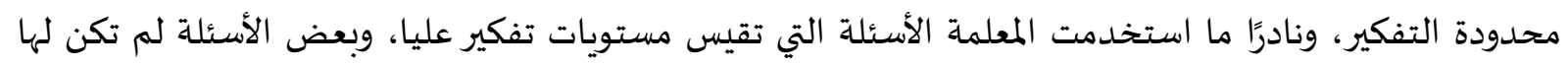

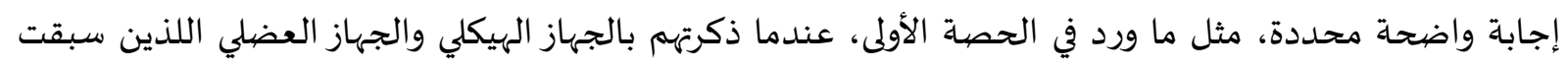

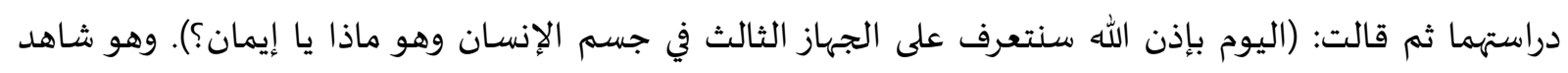

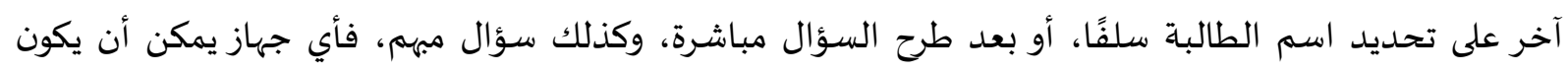
صحيحًا، والسؤال أصبح عبارة عن عملية تخمين من بين أجهزة جسم الإنسان، وليس سؤالاً علميَّا مضبوطًا.

سـادسًا: المعلمة (6)

لاحظت الباحثة أن المعلمة (6) نوّعت في أساليب التقويم التكويني المستخدمة، إذ كان أسلوب الأسئلة

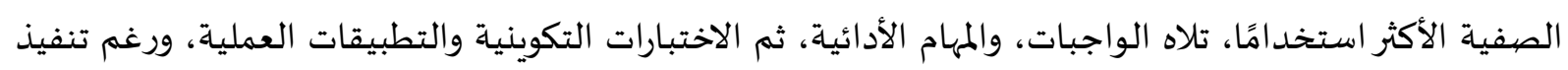

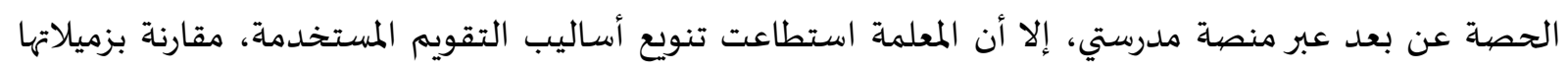

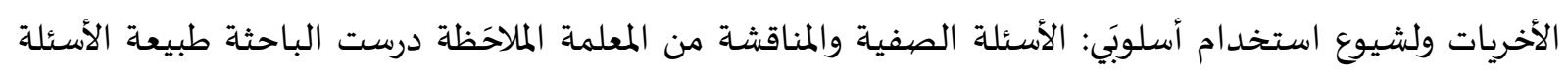

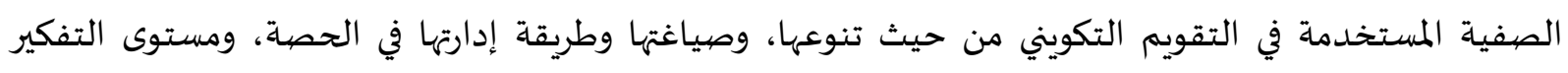
الذي تتطلبه.

واطلعت الباحثة على الحصة المفرغة وقرأتها عدة مرات ورمَّزت طبيعة الأسئلة الصفية؛ للوقوف على

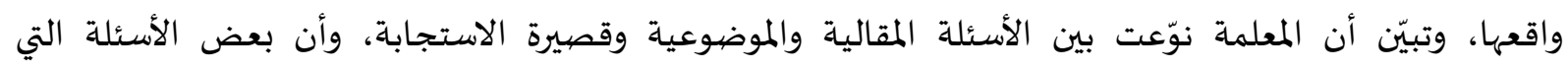

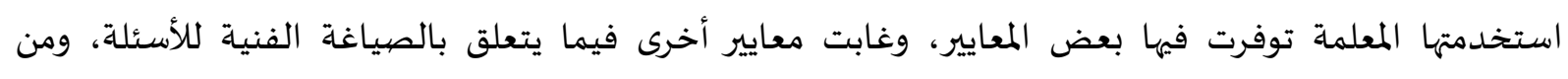

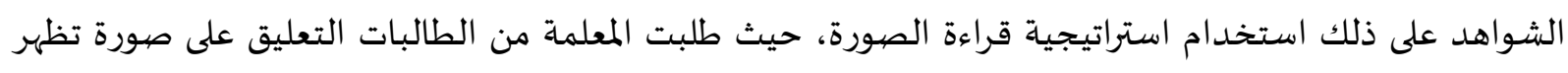

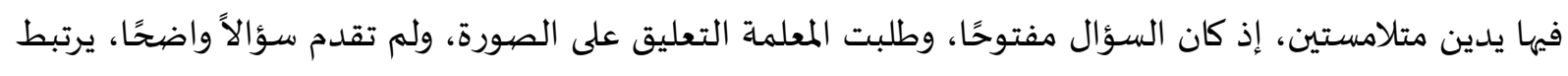

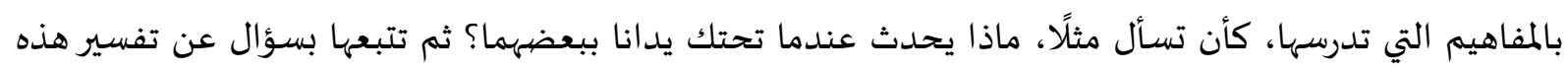

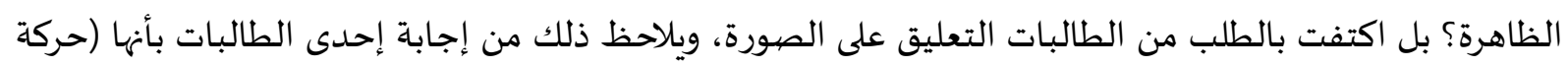

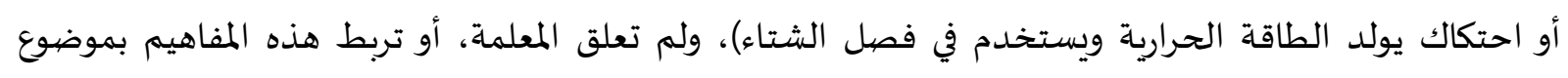


الدرس الذي كان عن الاحتكاك السكوني والاحتكاك الحركي، وكان من الممكن اختيار صور أو فيديوهات أخرى،

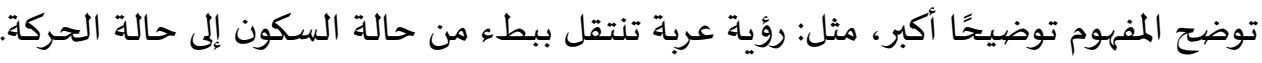

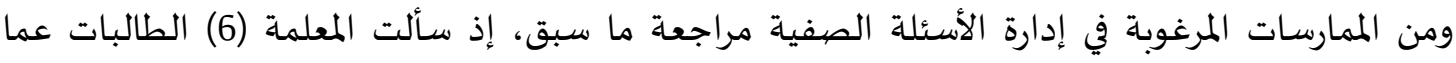

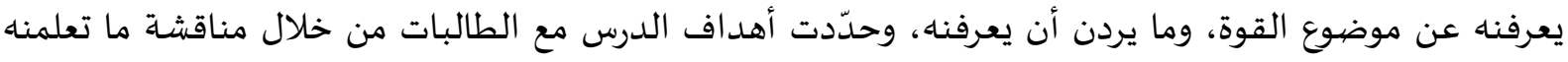

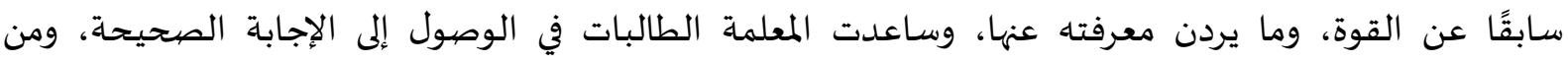

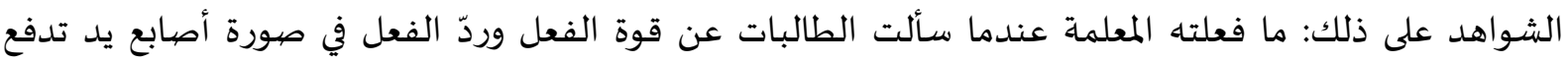

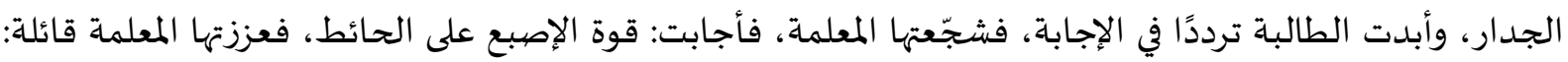

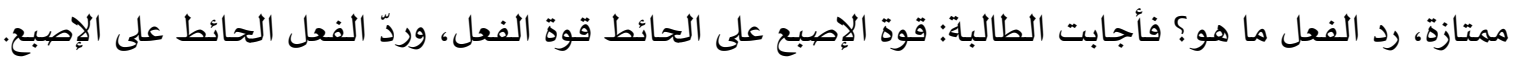

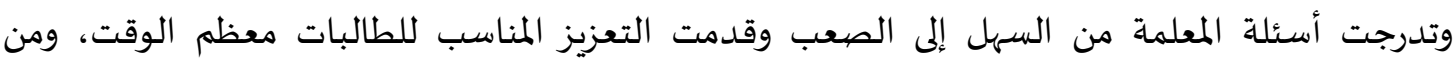

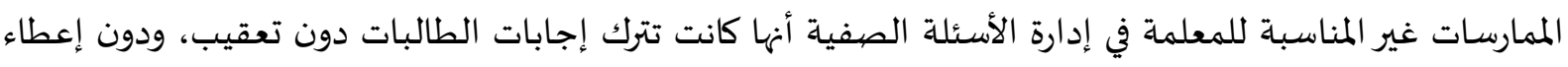

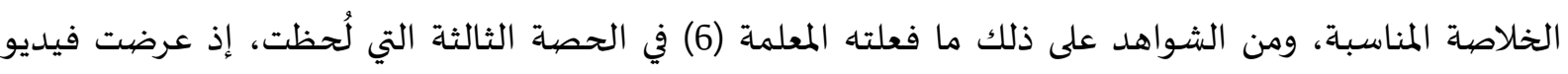

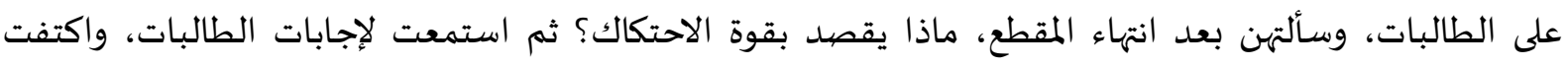

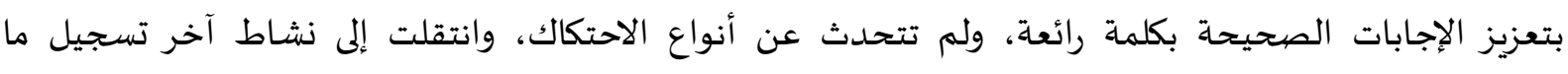

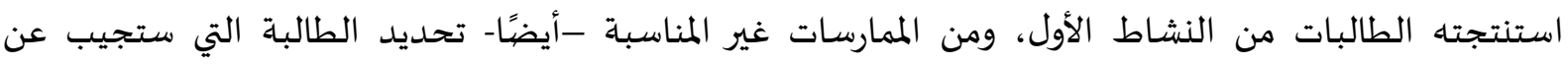

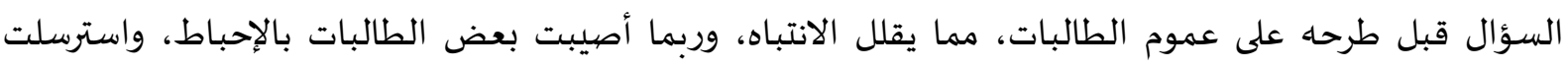

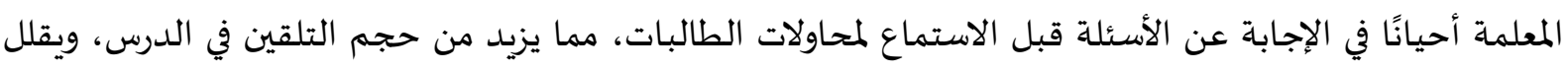

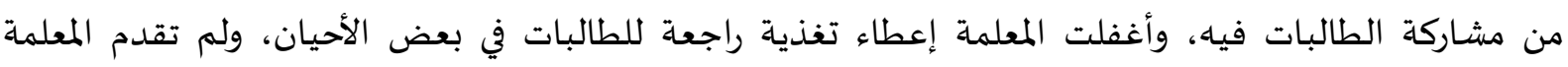

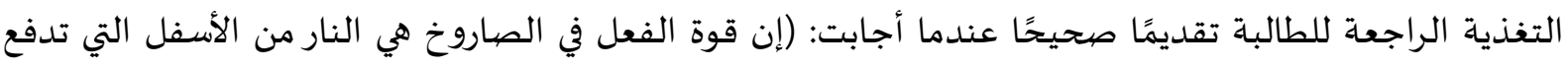

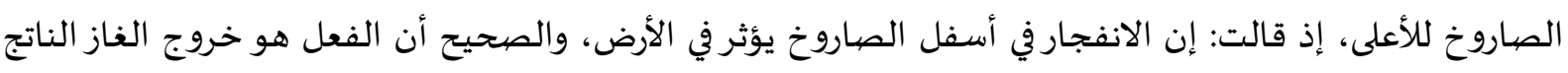

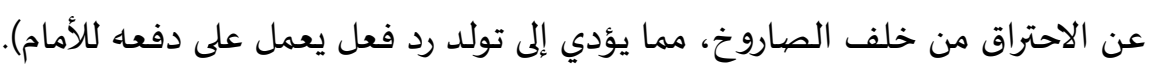

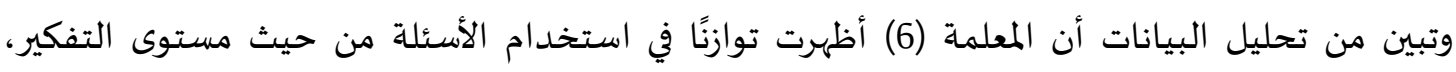

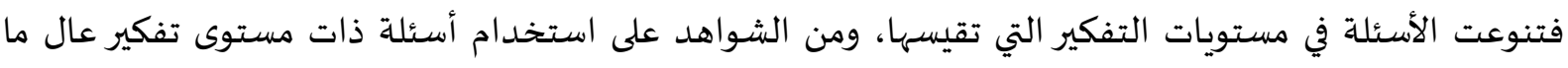

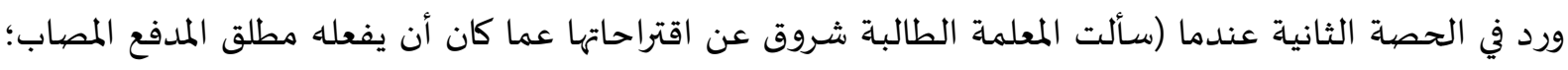

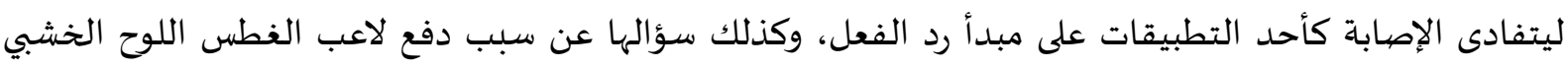
لكلأسفل عند القفز من فوقها في حمام السباحة).

\section{تحليل ممارسات معلمًات العلوم لأساليب التقويم التكويني}

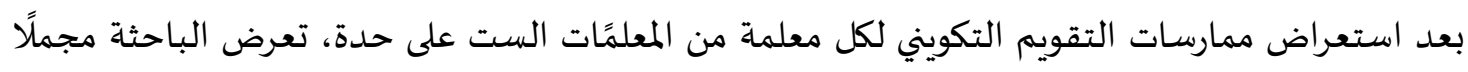

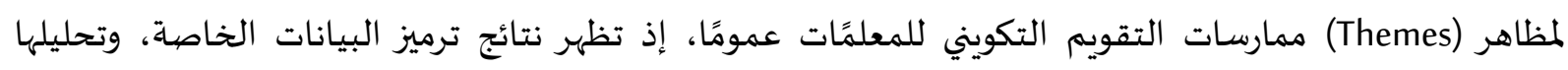

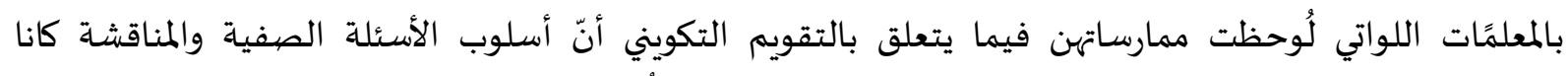

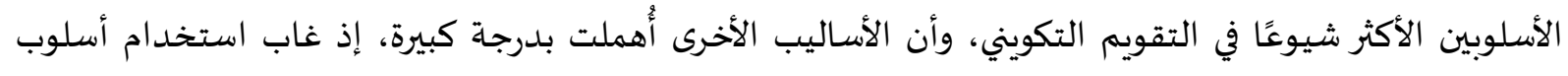

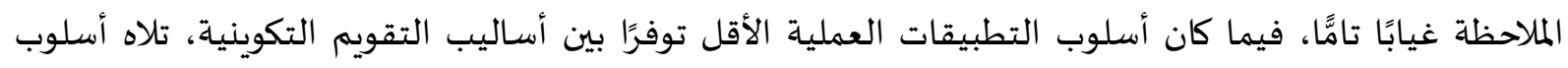

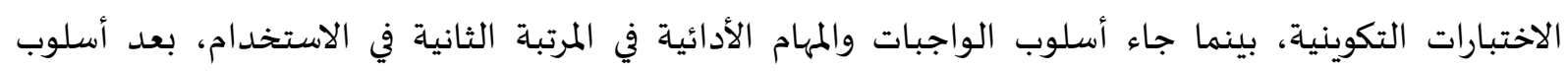

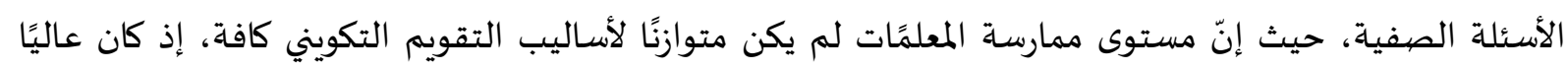

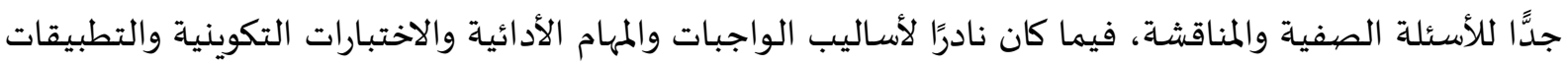




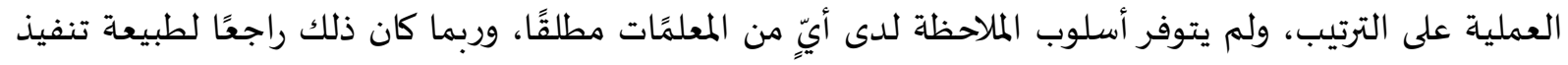

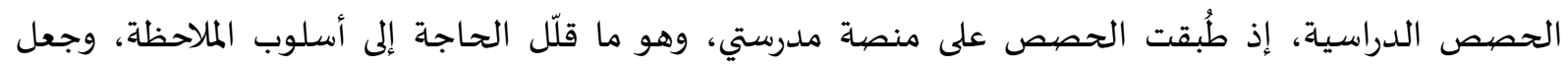

تطبيقه عسيرًا.

وكون الأسئلة الصفية الأسلوب الأكثر شيوعًا من بين ممارسات التقويم التكويني لدى معلمًات العلوم،

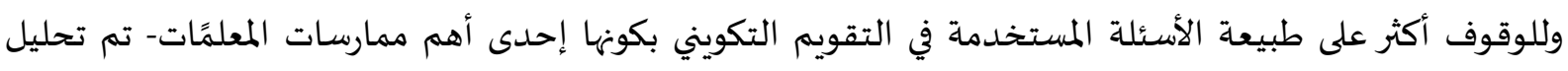

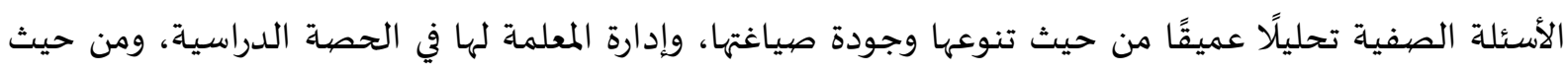

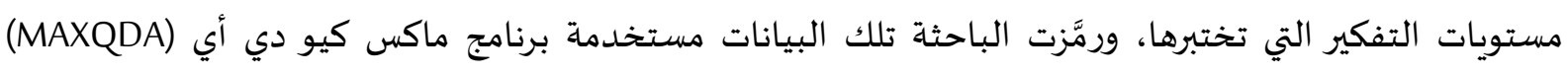

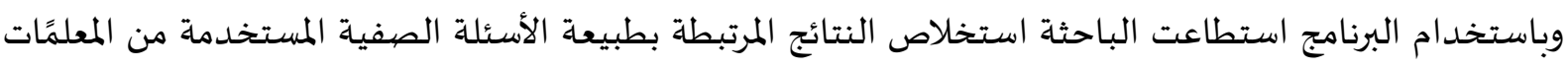

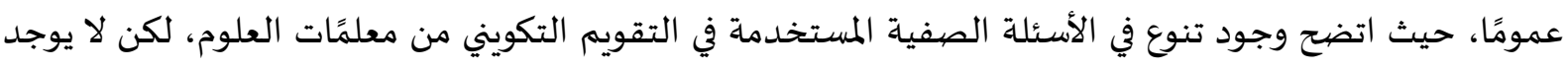

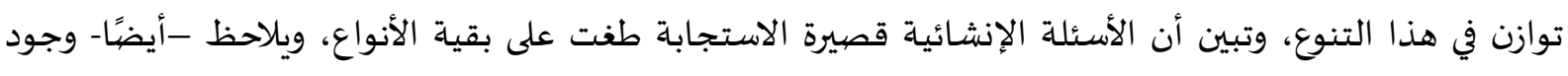

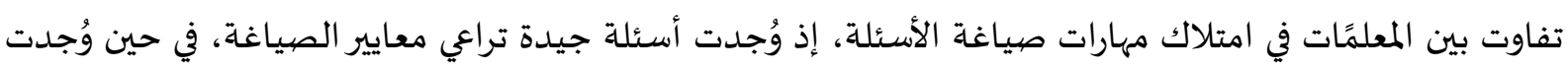
أسئلة، تفتقر لتلك المعايير. وما يخصّ إدارة الأسئلة الصفية من المعلمًات فإن الممارسات المرغوبة أكثر توفرًا من الممارسات غير السليمة

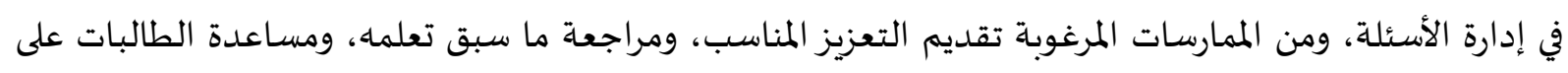

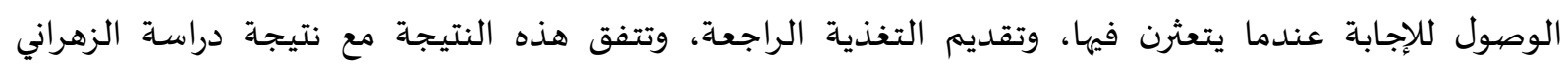
(Alzahrani. 2017)

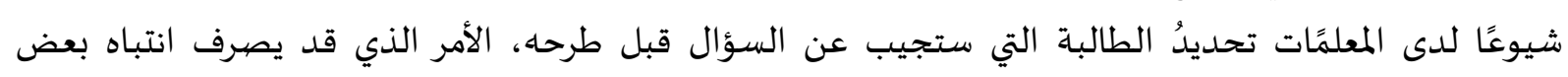

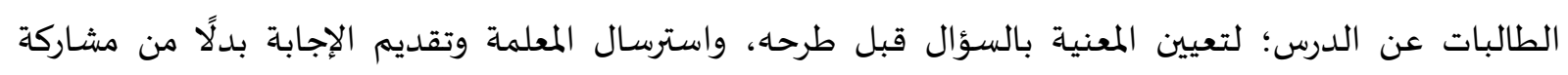

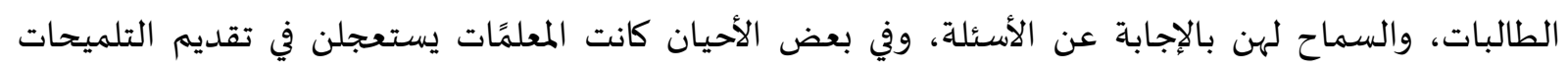

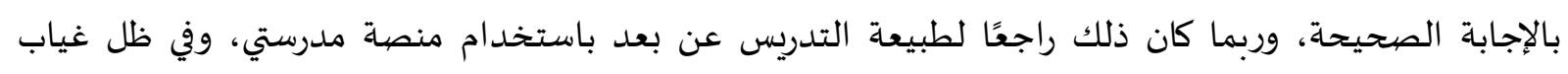

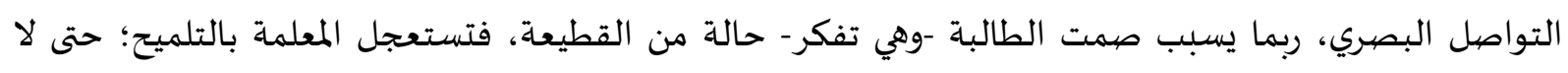

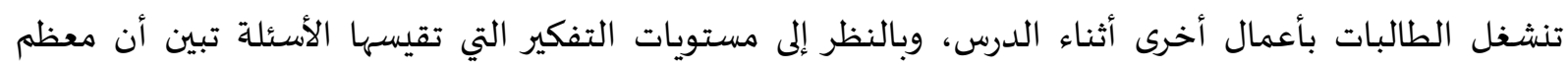

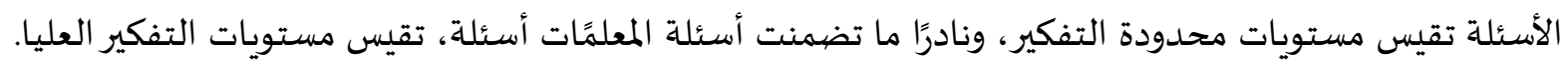

نتائج السؤال الثاني: "هل توجد علاقة بين مستوى معرفة معلمات العلوم في المرحلة الثانوية لأساليب

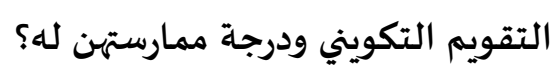

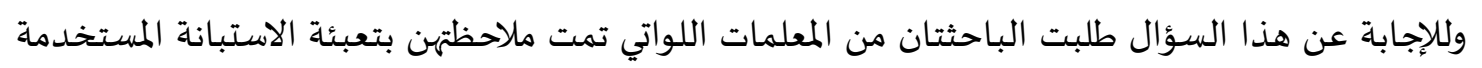

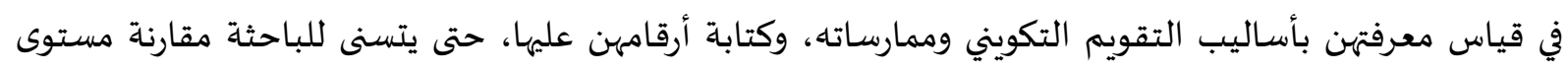

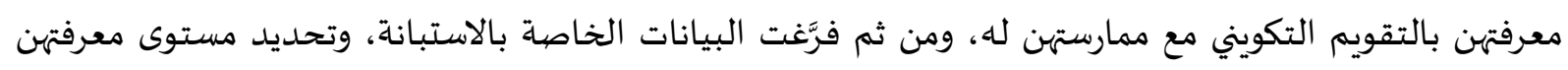

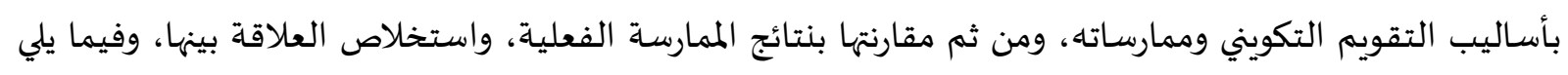
عرض لما أظهرته تلك المقارنة.

أولا: المعلمة 1

وصفتِ المعلمة معرفتها بأربع ممارسات بالعالية، وهي أُوظِّف الواجبات المنزلية؛ لتحديد نقاط القوة ونقاط

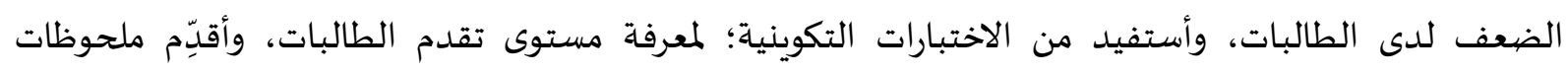

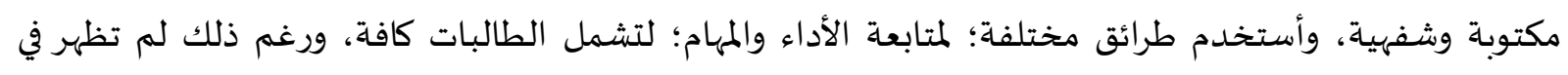


ممارساتها بالدرجة نفسها التي وصفتها، وربما قصدت المعلمة بالاختبارات الدورية الاختباراتِ الشهريةً ونصف

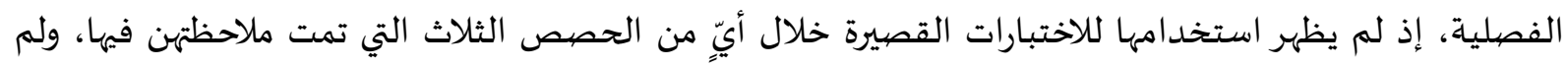

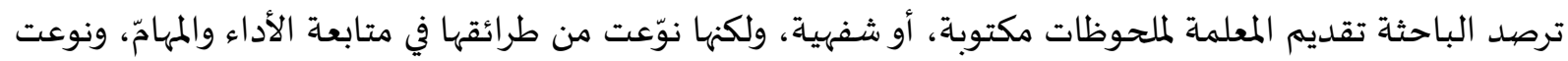
من الأسئلة؛ لتشمل أكبر عدد من الطالبات تقديم المعلمة كلموطات مكتوبة ومما سبق يتضح وجود اتساق كبير بين معرفة المعلمة منيرة بأساليب التقويم التكويني وممارساته، وبين

ممارساتها الفعلية كما رصدتها الباحثة من خلال ملاحظتها لها.

ثانيًا: المعلمة 2

ذكرت المعلمة في استجابتها للاستبانة التي تقيس مستوى معرفتها بالتقويم التكويني بأن مستوى معرفتها

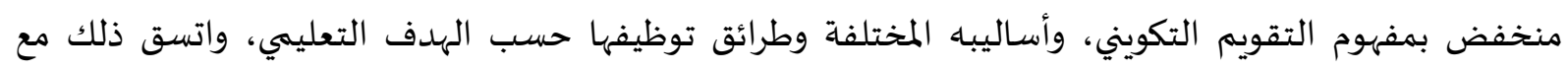

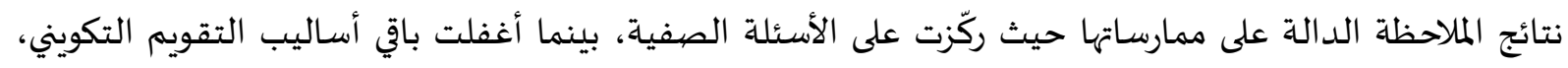

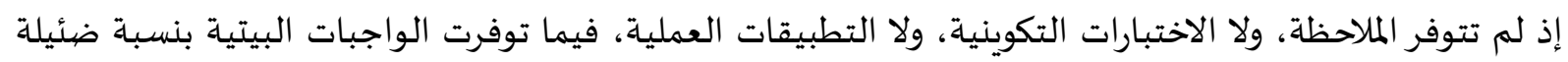

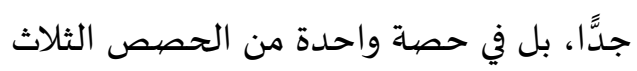

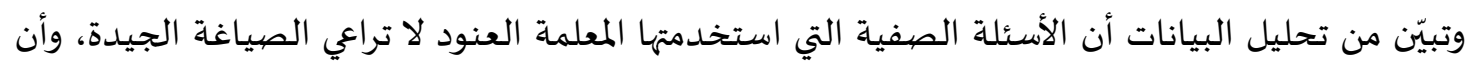

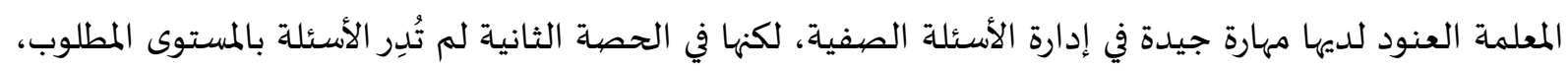

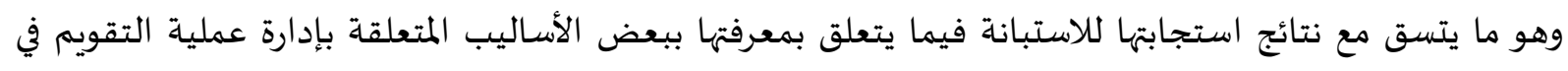
الصف، فنجدها قد أعطت تقديرات منخفضة لمعرفتها بطرائق تصويب مسار عملية التعلم وطرائق توجيه التغذية

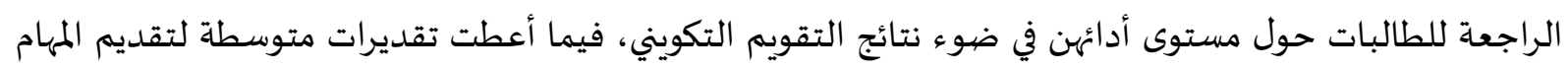

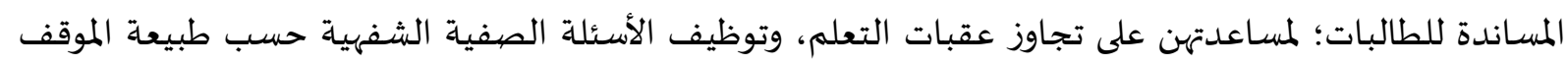
التعليمي، وتصميم معايير الأداء الصحيح، ومؤشراته قبل البداء باون بالتدريس.

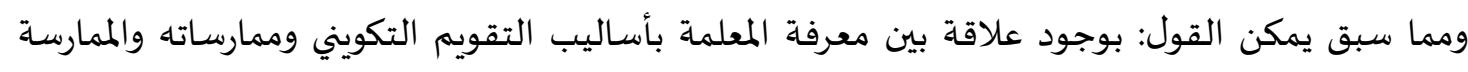

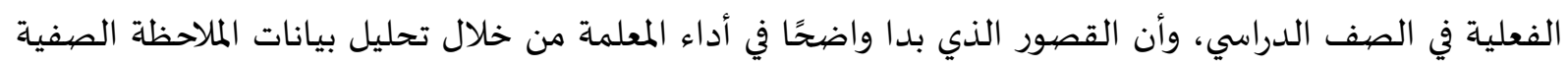

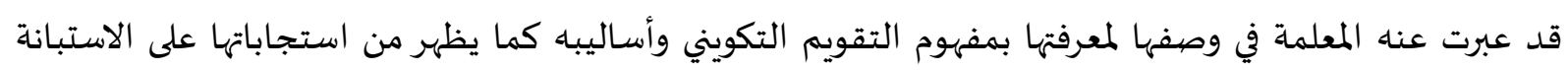
الخاصية بهذا المحور.

ثالثًا: المعلمة 3 اتفقت نتائج ملاحظة ممارسات المعلمة مع نتائج استجاباتها على استبانة معرفة التقويم التكوني وأساليبه،

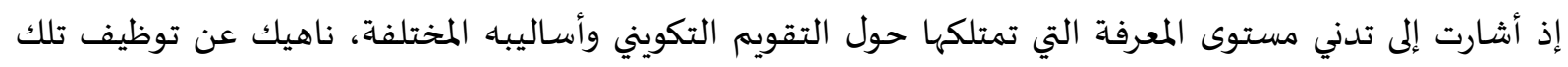

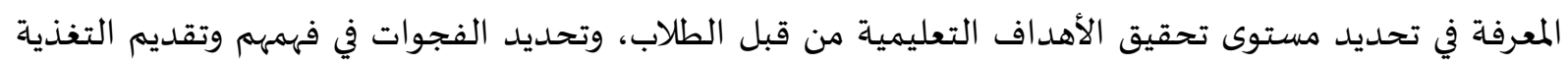

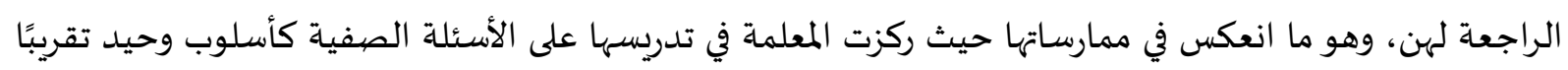

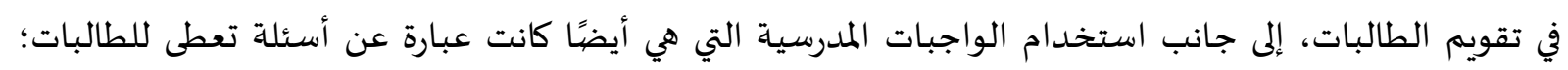

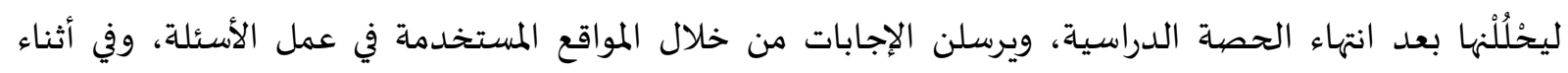

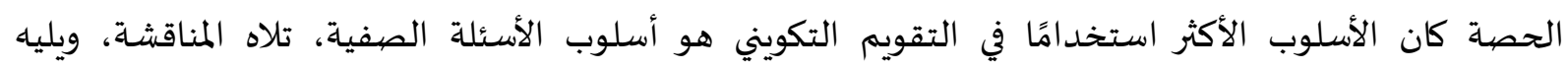

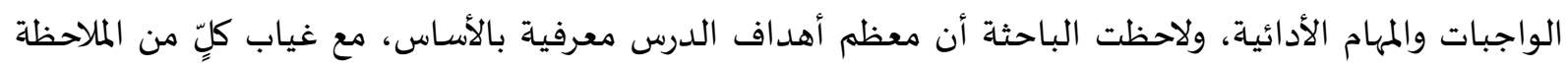

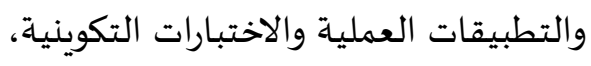


ويظهر من تحليل ممارسات المعلمة أن لديها مهارات جيدة في إدارة الأسئلة إجمالًا، ومن أمثلة ذلك أنها كانت

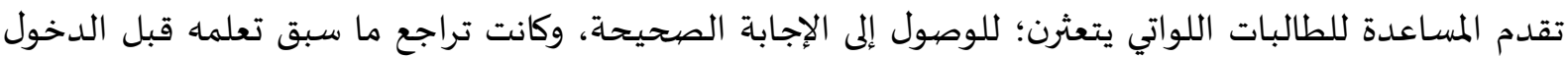

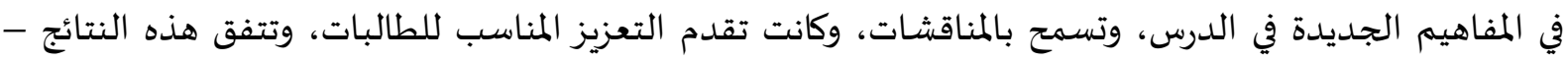

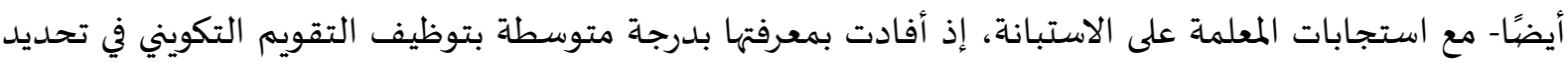
نقاط القوة والضعف عند الطالبات.

وكذلك الحال فيما يتعلق بتقديم التغذية الراجعة للطالبات فقد كانت مقلة في تقديمها، ولم تسمح

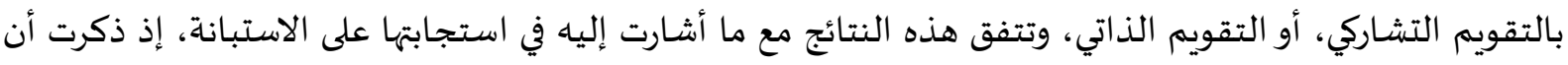

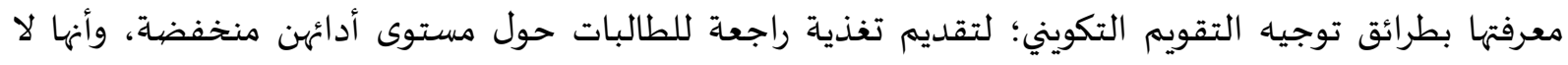
تمتلك معرفة بطرائق تصويب مسار التعلم في ضوء نتائج عملية التقويم التكويني، وتشجيع التقويم التكويني المتبادل بين الطالبات والتقييم الذاتي.

رابعًا: المعلمة 4

وتبين نتائج التحليل للبيانات المستخلصة من بطاقات الملاحظة أن المعلمة تركز في تدريسها على أسلوبَي:

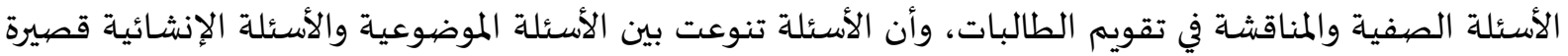
الاستجابة، فيما غابت الأسئلة المقالية عن الحصاة، وتتفق هذه النتيجة مع ما أشارت إليها نتائج الاستبانة المتعلقة

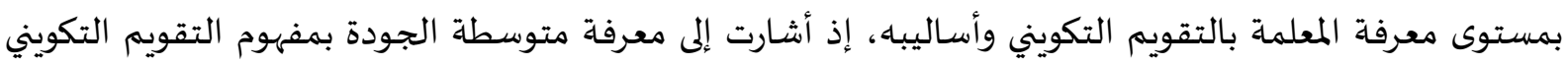
وأساليبه المختلفة، وتوظيفها حسب الهدف التعليمي.

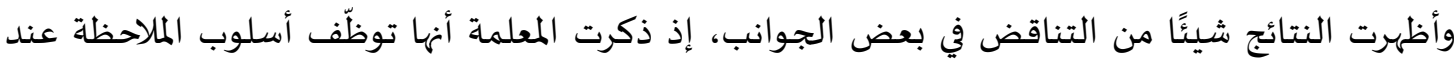

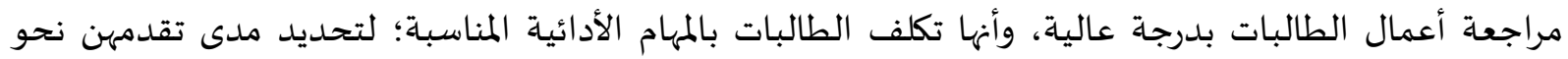

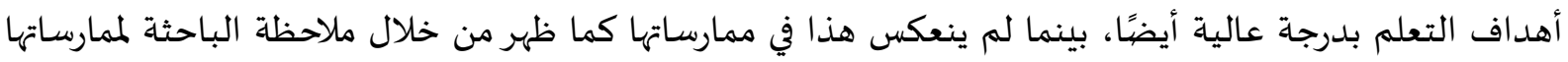
في الحصص الثلاث، وربما يكون ذلك راجعًا لأن معرفة المعلمة بتلك الأساليب نظرية أكثر منها تطبيقية.

خامسًا: المعلمة 5

وتظهر نتائج تحليل بيانات الملاحظة الصفية للحصص الثلاث للمعلمة 5 في مادة الأحياء أن استخدام

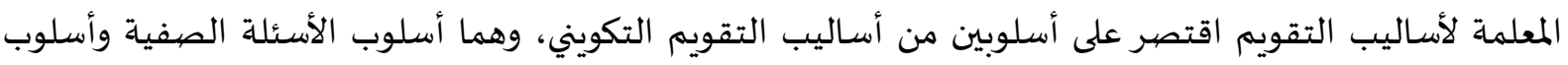

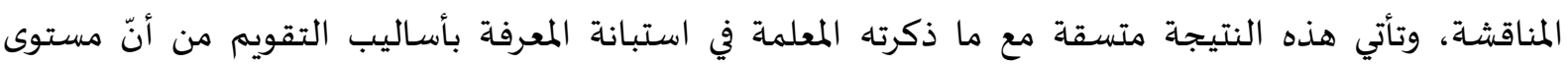
معرفتها متوسط بكل من: مفهوم التقويم التكويني والقدرة على توظيفه؛ لتحديد مستويات أداء الطالبات وتحقيقهن ماته للأهداف التعليمية.

وأوضحت المعلمة من خلال الاستبانة أن معرفتها بأساليب التقويم التكويني المختلفة عالية لكن ذلك لم

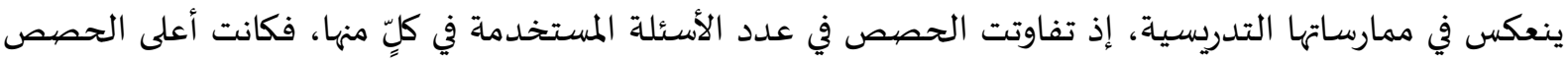

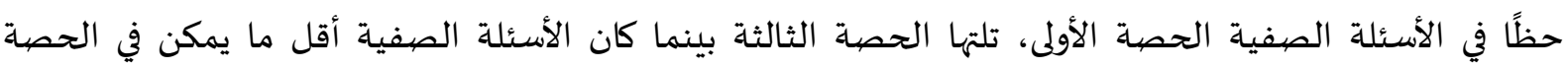

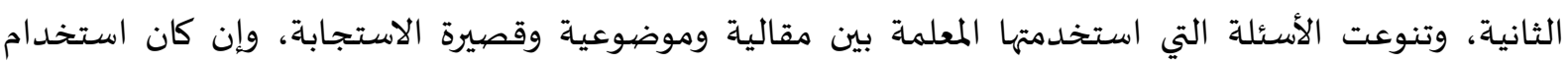
الأسئلة الموضوعية هو الأقل من بين الأنواع الأخرى. اتسقت نتائج تحليل البيانات النوعية المستخلصة من من ملاحظة المعلمة هيفاء الماء في جوانب إدارة المارة الأسئلة

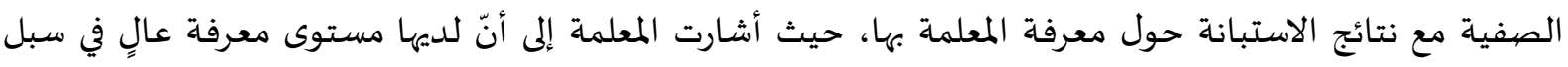

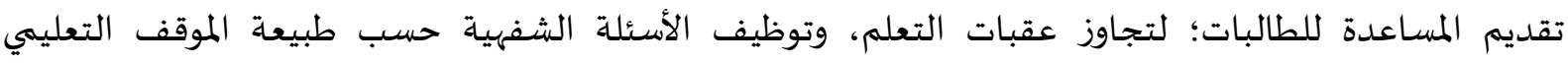


التعلمي، وهو ما ظهر في ممارساتها التدريسية مثل إعطاء وقت كاف للانتظار بعد سؤال الطالبات، ومساعدتهن على الواتى

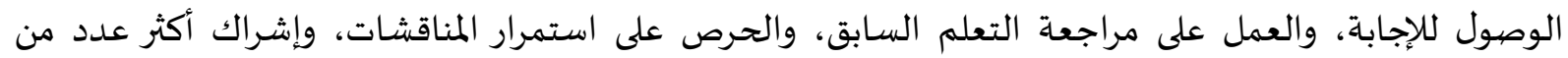
الطالبات فيها، وتقديم التعزيز المناسب، والتغذية الراجعة متى لزم الأمر، وجاء ذلك متسقًا مع نتائج الاستبانة التي التئي

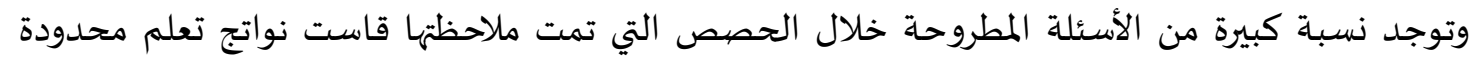

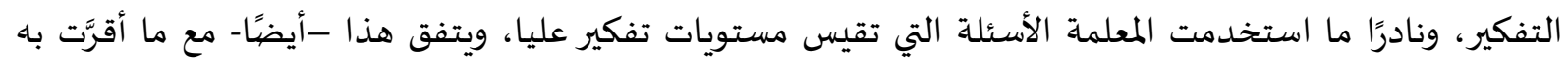

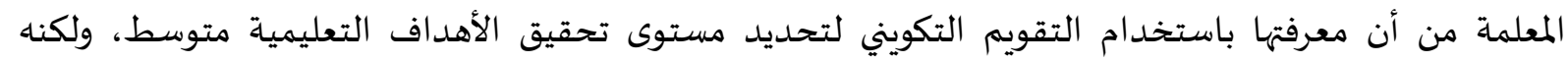
ناقض ما ذهبت إليه المعلمة من أنها تمتلك مستويً عاليًا من المعرفة بطرائق توظيف أساليب التقويم التكويني المناسبة حسب الهدف التعليهي.

سادسًا: المعلمة 6 استطاعت تنويع أساليب التقويم المستخدمة مقارنة بزميلاتها الأخريات اللواتي لُحِظن، وتتفق هذه النتائج

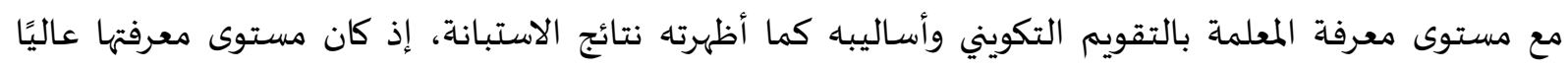

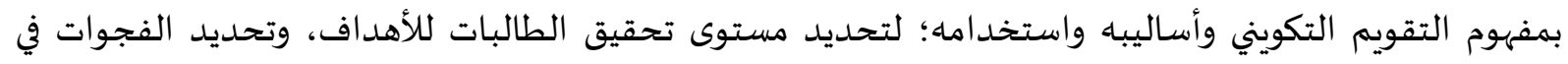

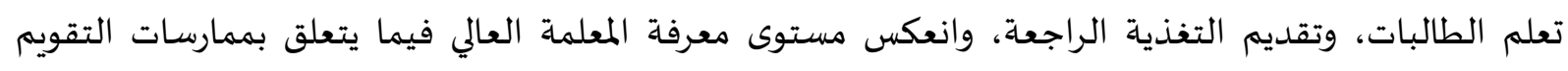

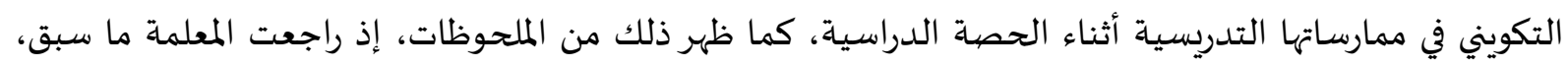
وحدّدت أهداف الدرس مع الطالبات وساعدتهن في الوصول إلى الإجابة الصحيحة.

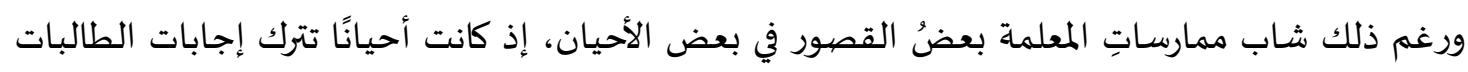

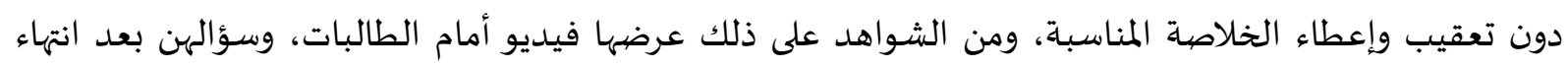

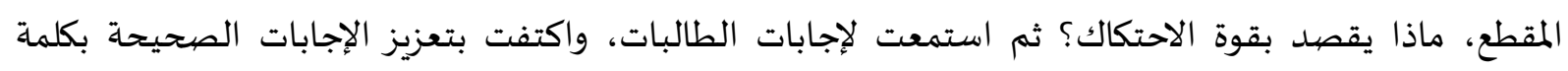

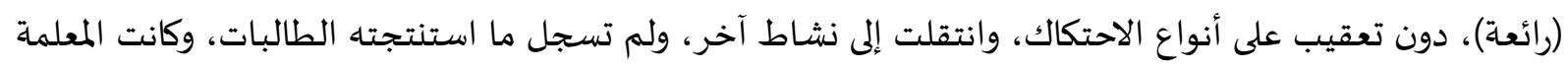

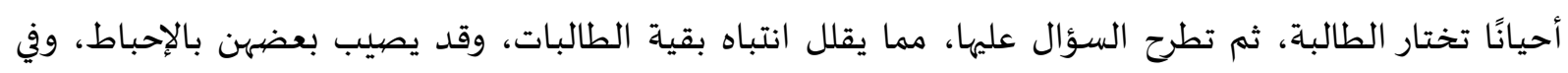

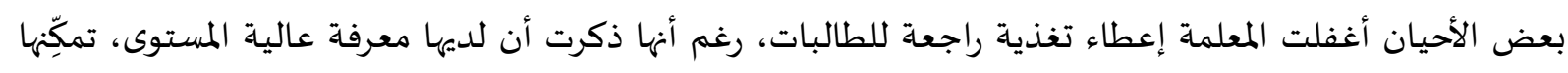
من توجياه التقويم التكويني لتقديم تغذية راجعة للطالبات حول مستوى أدائهن.

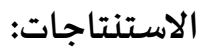

من خلال تحليل حصص المعلمًات المفرغة، يمكن ملاحظة عدة أمور تتعلق بممارسات المعلمًات فيما يتعلق بالتقويم التكويني من أهمها: 1. كانت ممارسة توضيح أهداف الحصة للطالبات في بداية كل حصة من الممارسات الشائعة لدى معلمًات

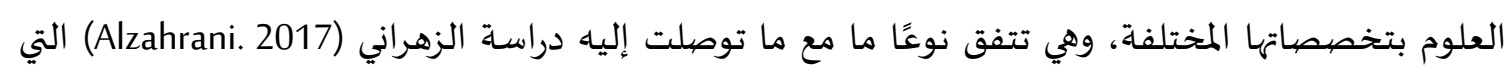

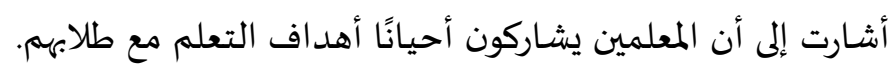

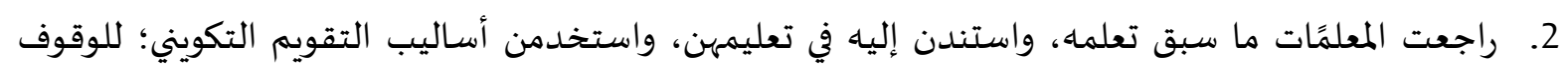

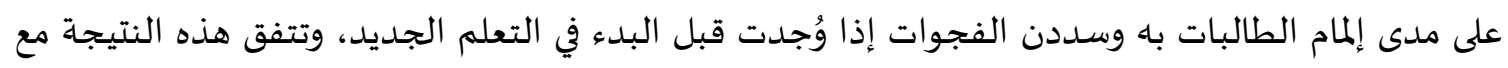

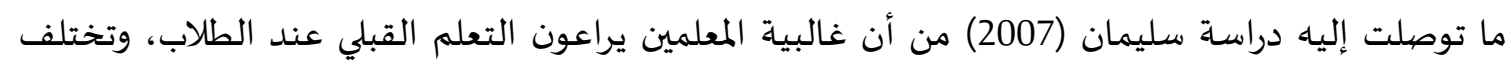

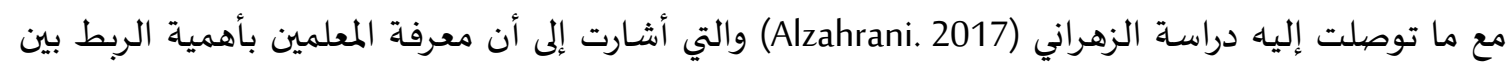
أهداف الدرس الحالي وأهداف الدرس السابق متوسطة الدئ. 
3. في معظم الأحيان قدمت المعلمًات المساعدة للطالبات عندما يحتجن إليها، ويعجزن عن تنفيذ المهام، أو الإجابة

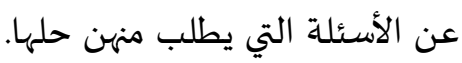
4. لم تستخدم المعلمًات أساليب تقويم تشاركية رغم توفر العديد من المنصات التئي توفر هذه الإمكانية، خصوصًا في حالات التعليم عن بعد، وتنسجم هذه النتيجة مع ما توصلت إليه دراسة الزهراني ( Alzahrani.

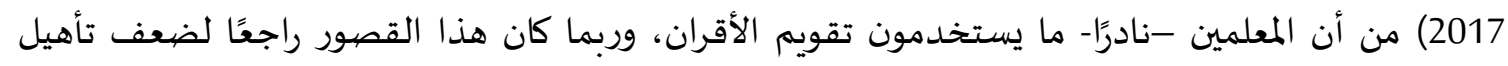

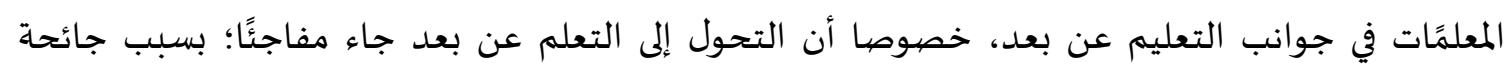

5. قدمت المعلمًات التغذية الراجعة للطالبات حول أدائهن أحيانًا، وغفلن عن ذلك أحيانًا أخرى، وتتفق هذه

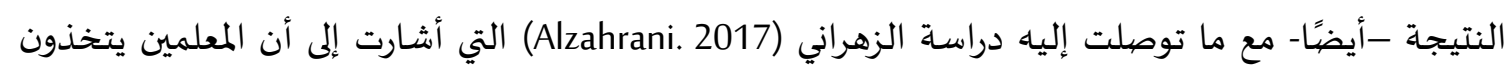

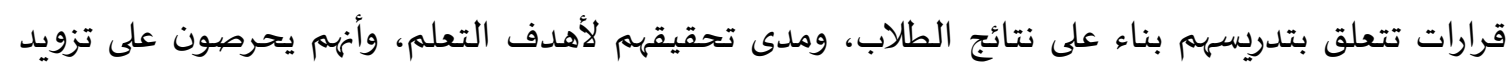

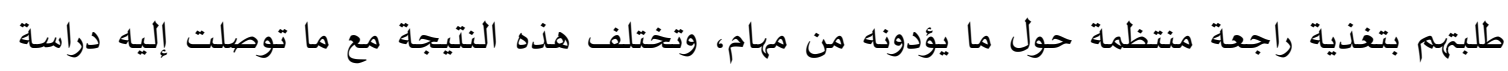

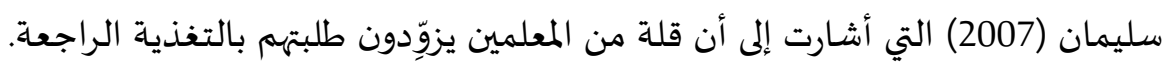

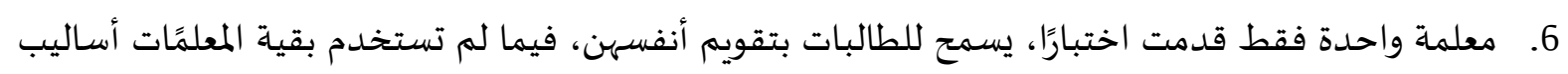
تقويم تكوينية ذاتية مشابهة، وتنسجم هذه النتيجة مع ما توصلت إليه دراسـة الزهراني (Alzahrani. 2017)

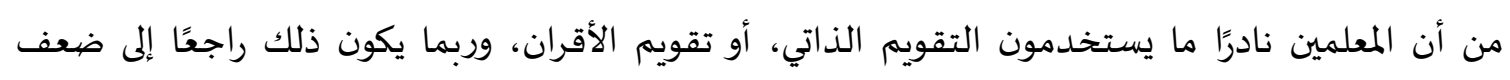

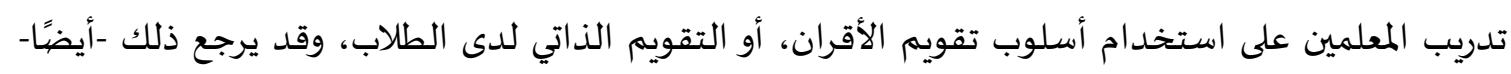
إلى اقتناع المعلمين وإيمانهم بجدوى هذه الأسماليب.

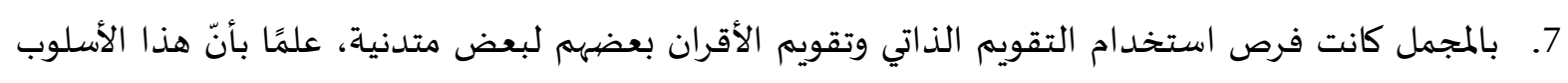

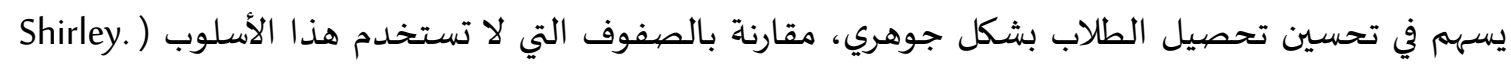

في ضوء ما توصلت إليه الدراسة من نتائج، توصي الباحثتان وتقترحان ما يلي: 1. عقد دورات تدريبية لمعلمًات العلوم؛ على توظيف التقويم التكويني وأساليبه في التدريس.

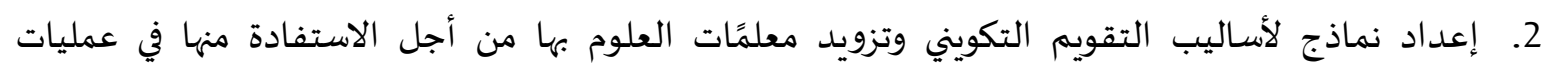
التقويم المستخدمة في تدريس العلوم.

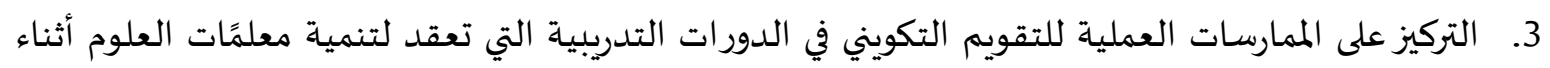

$$
\text { الخدمة وعدم الاكتفاء بالتركيز على الجوانب النظرية. }
$$

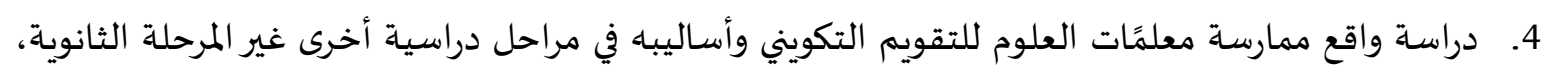

$$
\text { وفي مباحث أخرى غير العلوم. }
$$

5. إجراء دراسة تتناول معوقات ممارسـة التقويم التكويني في تعليم العلوم بالمرحلة الثانوية. 
- البرصان، إسماعيل؛ والرويس، عبد العزيز؛ وعبد الفتاح، فيصل (2015). الممارسات التقويمية التكوينية والختامية لمعّلمي الرياضيات في المرحلة المتوسطة في المملكة العربية السعودية. مجلة العلوم التربوية والنفسية، وعيل،

122-93 16

بروكهارت، سوزان (2015). استراتيجيات التقويم التكويني لكل صفف دراسي (ترجمة عبد الله زيد الكيلاني). مكتب التربية العربي لدول الخليج. (نشر الكتاب الأصلي 2010).

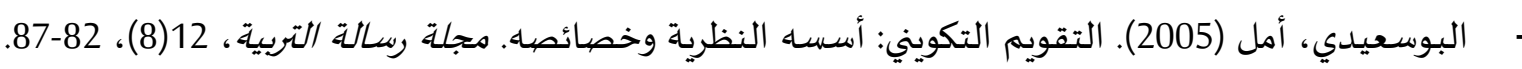

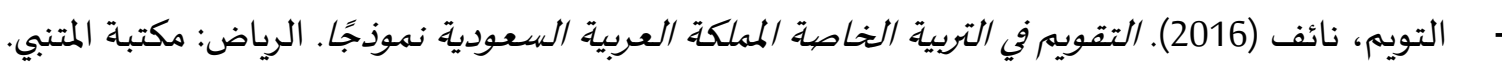

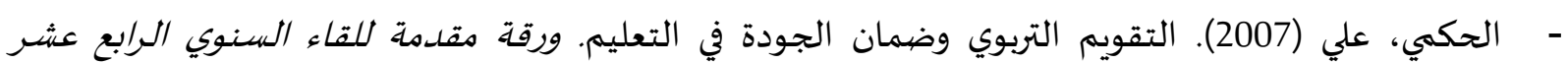

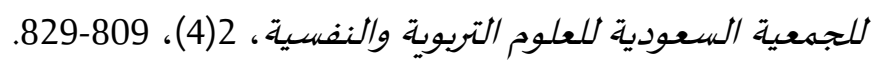

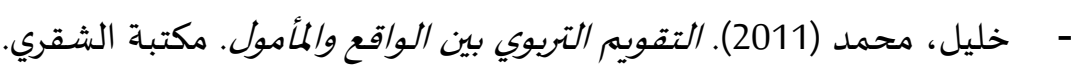

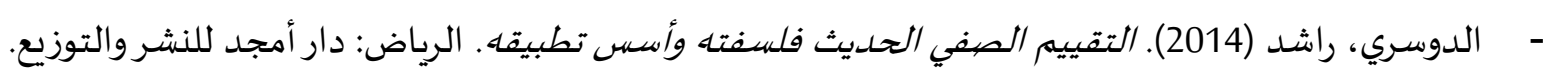

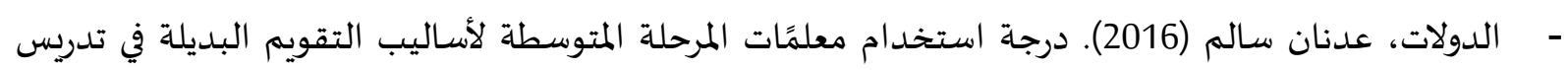

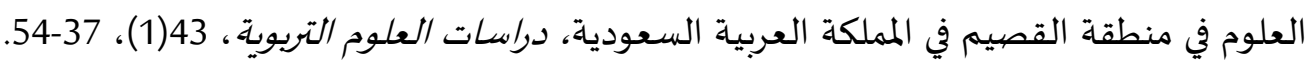

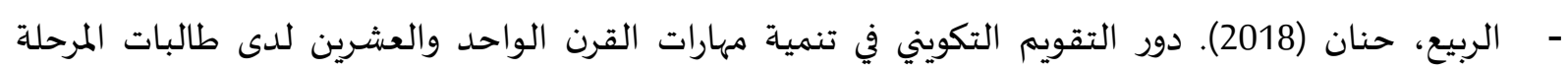

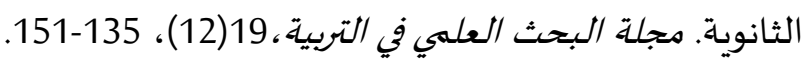

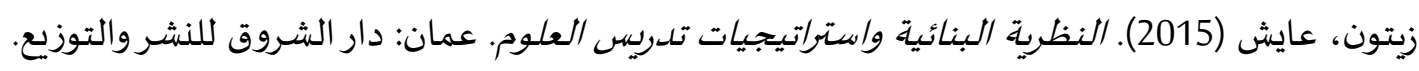

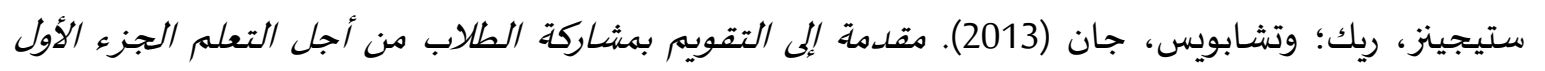

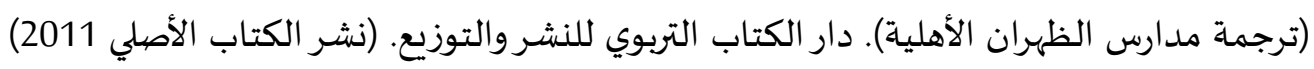

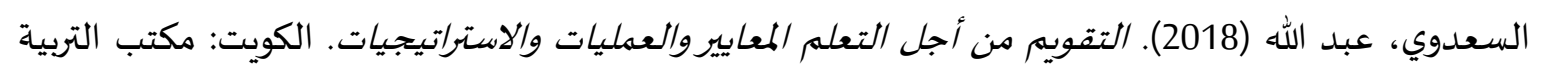
العربي لدول الخليج. سليمان، فرات (2007). مستوى معرفة معلمي العلوم في المرحلة الأساسية بمفهوم التقييم التكويني وممارستهم

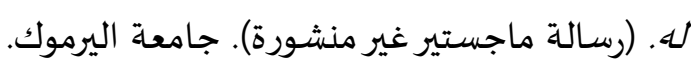

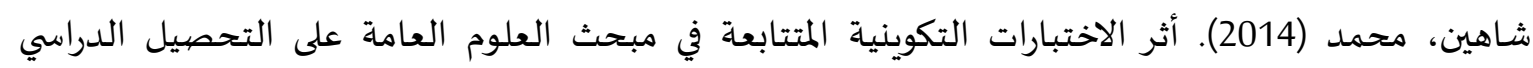

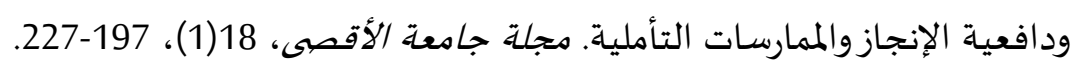

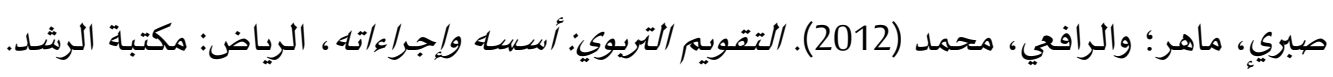

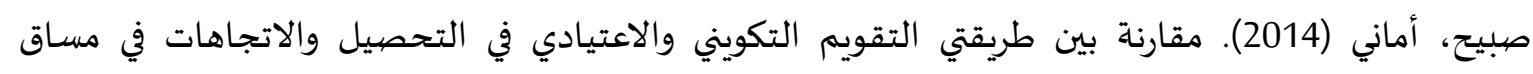

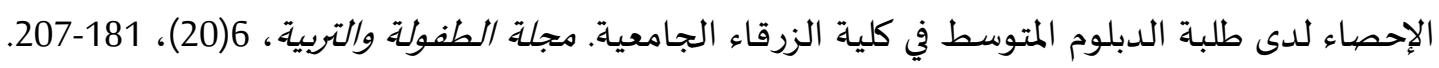

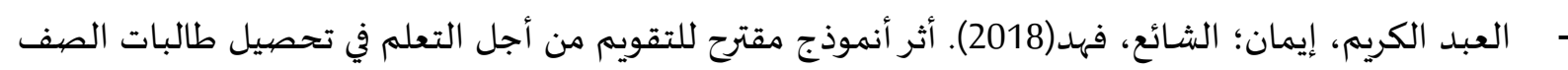

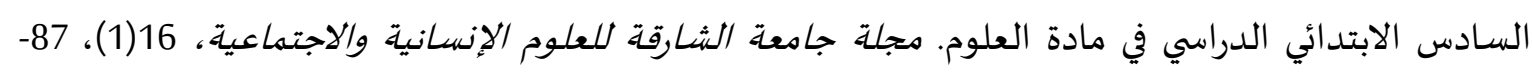

- عثمان، محمد (2011). أساليب التقويم التويوي. عمان: دار أسامه للنشر. 
- العجمي، عبد الله (2012). أثر استخدام استراتيجية التقويم التكويني في تنمية التحصيل الدراسي لطلاب الصف

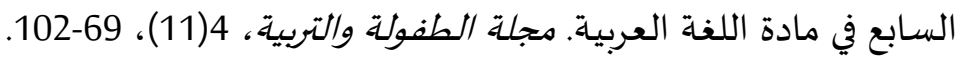
- العزيزي، عيسى بن فرج (2018). فاعلية استخدام التقويم التكويني في تحسين مستوى التحصيل لمقرر مهارات

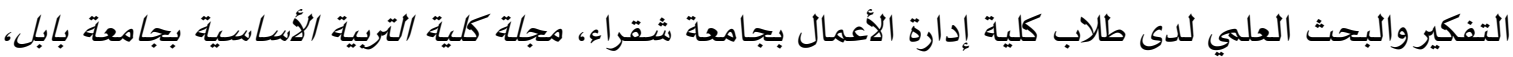

عطية، محسن (2008). الاستراتيجيات الحديثة في التدريس الفعًال. دار صفاء للنشر والتوزيع. علام، صلاح (2011). القياس والتقويم التويوي في العملية التدريسية (ط 4). عمان: دار المسيرة للنشر والتوزيع. فيشر، دوجلاس؛ وفراي، نانسي (2016). تعلم أفضل من خلال تدريس منظم إطار نقل المسؤولية بالتدريج

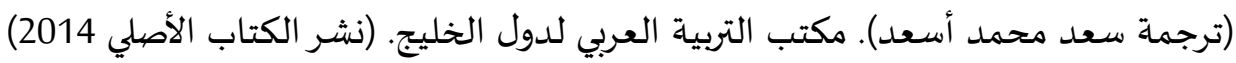

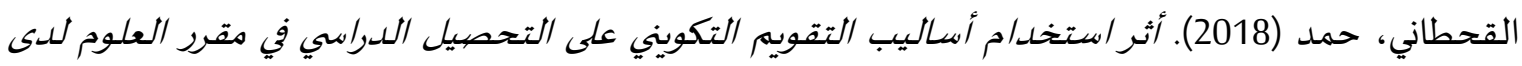

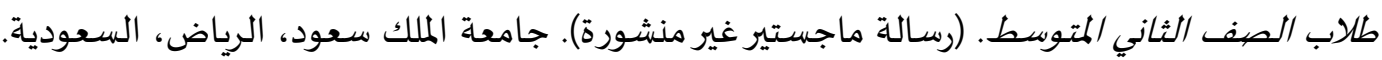
مارون، جورج (2010). أسس التقويم التوبوي ومعاييره. لبنان، طرابلس: المؤسسة الحسيرة التديثة للكتاب.

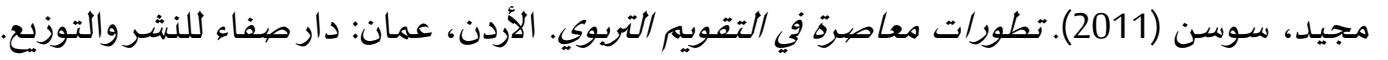

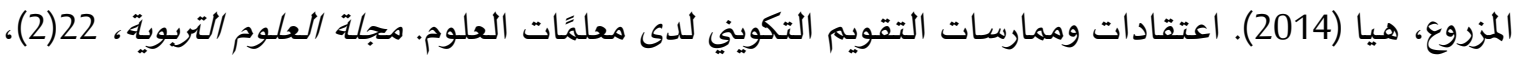
$.315-279$ مصطفى، علي؛ وسند، فتحي (2016). التقويم التوبوي المتقدم في ضوء معايير الجودة. الرياض: دار الزهراء للنشر والتوزيع.

المطرودي، خالد (2014). أثر استخدام استراتيجية التقويم التكويني على تحصيل التلاميذ وبقاء أثره في مقرر

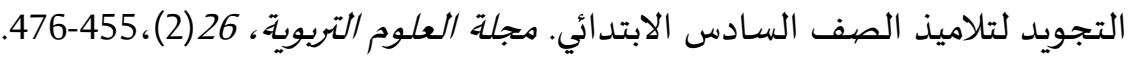

هاشم، كمال؛ والخليفة، حسن (2017). التقويم التربوي، مفهومه، أساليبه، مجالاته، توجهاته الحديثة (ط6)، عمان: مكتبة الرشـد. وزارة التعليم (2018). دليل التعليم الثانوي نظام المقررات الإصدار الأول. (بدون رقم نشر). استرجعت من https://www.moe.gov.sa/ar/news/Documents/edu-guide.pdf

ثانياً- المراجع بالإنجليزية:

- Alzahrani, S. (2017). Saudi Mathematics Teachers' Understanding and Practices of Formative Evaluation in Elementary Schools (Publication No. 10637319) [Doctoral dissertation, Southern Illinois University Carbondale]. ProQuest Dissertations Publishing.

- Black, P., \& Wiliam, D. (2009). Developing a theory of formative evaluation. Education evaluation, Evaluation, and Accountability, 12(1), 1-39. doi: 10.1007/s11092-008-9068-5.

- Brookhart, C \& Long, B. (2008). Formative evaluation. Educational Leadership, 66(3), 52-57.

- Chappuis, L. (2018). Research methods in education, London: Routledge.

- Clark, I. (2012). Formative assessment: Assessment is for self-regulated learning. Educational Psychology Review, 24, 205-249 
- Cohen, L., Manion, L., \& Morrison, K. (2011). Research Methods in Education (7th ed.). London: Routledge.

- Duckor, B. (2014). Formative Evaluation in Seven Good Moves. Educational Leadership,71(6), 28-32. Retrieved 14 JUN, 2019 from https://www.researchgate.net/publication/289774573_Formative Evaluation_in_Seven_Good_Moves

- Furtak, E.M., and Ruiz-Primo, M.A. (2008). Making students' thinking explicit in writing and discussion: An analysis of formative evaluation prompts. Science Education, 92(5), 798-824.

- Ginsburg, H. P. (2009). The challenge of formative assessment in mathematics education: Children's minds, teachers' minds. Human Development, 52(2), 109-128

- Kleghan, I. (2011). Formative evaluation: Evaluation is for self-regulated learning. Educational Psychology Review, 24, 205-249

- Kreswell, J. (2012). Qualitative inquiry and research design: choosing among five traditions, London: SAGE Publications.

- Laveault, D. \& Allal, L. (2016). Evaluation for Learning: Meeting the Challenge of Implementation. Springer Publications. DOI 10.1007/978-3-319-39211-0.

- Marzano, R. (2009). Targets, objectives, standards: How do they fit? Educational Leadership, 70(8), 82-83.

- Marzano, R. (2012). The many uses of exit slips. Educational Leadership, 70(2), 80-81.

- Mintert, A. (2019). The Effects of formative evaluation on student motivation for learning and achievement in standards-based grading [Doctoral dissertation, Southern Illinois University Carbondale]. ProQuest Dissertations Publishing.

- Prashanti, E., \& Ramnarayan, K. (2019). Ten maxims of formative.

- Topping, K. J. (2013). Peers as a Source of Formative and Summative Assessment. In J. H. McMillan (Ed.), SAGE Handbook of Research on Classroom Assessment. Thousand Oaks: SAGE Publications, Inc.

- Volante, L., \& Beckett, D.)2011(. Formative evaluation and the contemporary classroom: Synergies and tensions between research and practice. Canadian Journal of Education, 34(2), 239-255.

- Watkins, L. (2018). The best practices of formative evaluation (Publication No. 10846547) [Doctoral dissertation, Indiana State University]. ProQuest Dissertations Publishing.

- Wiliam, D. (2013). Assessment: The bridge between teaching and learning. Voice from the Middle, 21(2), 15-20 Retrieved on 2 jul 2019 from https://www.ncte.org 